\title{
Estoque de carbono em paisagens tropicais fragmentadas
}

\section{Carbon stocks in the tropical fragmented landscapes}

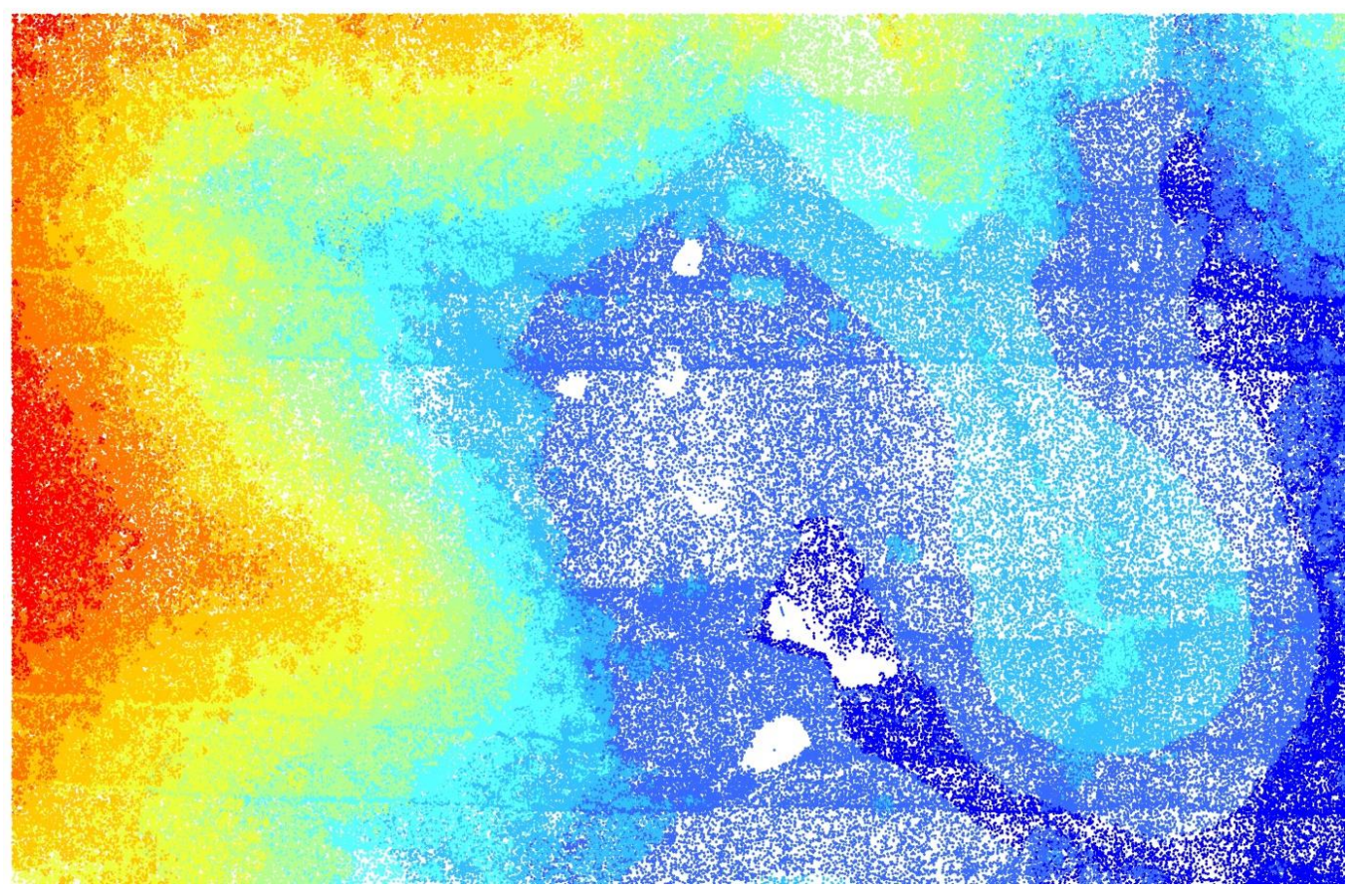

Isabella Romitelli

São Paulo 
Isabella Romitelli

\section{Estoque de carbono em paisagens tropicais fragmentadas}

\section{Carbon stocks in the tropical fragmented landscapes}

VERSÃO CORRIGIDA

Tese apresentada ao Instituto de

Biociências da Universidade de São Paulo, para a obtenção de Título de Doutorado em Ciências, na Área de Ecologia.

Orientador: Jean Paul Walter Metzger

Coorientador: Jomar Magalhães Barbosa

São Paulo 


\section{Ficha Catalográfica}

Romitelli, Isabella. Estoque de carbono em paisagens tropicais fragmentadas

126 páginas

Tese (doutorado) - Instituto de Biociências da Universidade de São Paulo. Departamento de Ecologia.

1. Florestas secundárias 2. Biomassa 3. Mata Atlântica I. Universidade de São Paulo. Instituto de Biociências. Departamento de Ecologia.

\section{Comissão Julgadora}

Profa. Dr. (a) Adriana Martini

Profa. Dr. (a) Pedro Brancalion

Profa. Dr. (a) Jayme Prevedello

Prof. Dr. Jean Paul Walter Metzger 


\section{Dedicatória}

Dedico essa tese a toda jovem comunidade científica. Ser cientista num ambiente com muitas adversidades não é uma tarefa fácil, mas enxergar a resistência e resiliência em cada um de vocês, me fortalece! 


\section{Epígrafe}

"Para nacer, sólo basta un empujón

La vida viene y no depende de un millón Para aprender a pararse, hay que intentar

Lanzarse al suelo y volverse a levantar

Y caminando no serás el más veloz Pero el paisaje suele ser mucho mejor El mundo entere rodará bajo tus pies

De ti depende, lo que quieras recorrer"

"Monsieur Periné - No Hace Falta" 


\section{Agradecimentos}

Conseguir agradecer em poucas palavras as pessoas que ajudaram a fazer desse tese, uma tese, é talvez o maior desafio que eu tive no doutorado. Foram quatro anos de muito aprendizado, superação de obstáculos, viagens, encontros e despedidas. Mas eu consegui, ao fazer uma análise do que foram esses 30 meses, traçar um paralelo do tema da minha tese.

Eu, assim como as florestas secundárias da Mata Atlântica, sofri a influência de fatores em escala local e numa escala mais ampla. Foram muitas adversidades que encontrei nessa zona, como por exemplo, reprovação no exame de qualificação, rejeições, pedidos de prorrogação realizados e conflitos acadêmicos e não acadêmicos. Nesses momentos, era difícil não sentir sob o padrão usual de resposta a esses fatores, com regeneração lenta e perda substancial de energia para se estar de pé. Mas eu fui entendendo que todas essas variáveis interagiam negativamente com outras variáveis que também existem nessa zona da pós-graduação, de alta exposição e vulnerabilidade, como a conexão com outras florestas de pessoas, que estavam na borda como eu, ou que já estavam recuperadas e mais estruturadas ao ponto de poder contribuir com minha regeneração e crescimento. Essa conexão foi feita por muitos processos baseados em companheirismo, afeto e carinho. E aí nessa região exposta e vulnerável a todas essas variáveis, no fim, eu obtive um padrão inesperado, onde todas essas variáveis (positivas e negativas) me permitiram crescer, me recuperar e apresentar uma estruturação que fugia da resposta comum que se esperava a partir de toda trajetória apresentada. Eu espero, que esse padrão inesperado também seja mais comum do que se esperava e aconteça em diferentes contextos para outras florestas.

Gostaria de agradecer a todas as pessoas que estiveram nessa trajetória acompanhando todas as etapas do doutorado e que me ajudaram com fatores positivos na minha regeneração.

Agradeço ao Jean Paul, por me dar mais uma vez a oportunidade de realizar a pesquisa que eu queria e fomentar as ferramentas necessárias para isso. Muito obrigada por confiar em mim e me dar tanta autonomia, o que fomentou minha autoconfiança e segurança ao longo do projeto. Não posso deixar de agradecer também a todos os esforços que fez ao corrigir versões dos meus artigos tão rápido e de forma tão efetiva, inclusive em 
alguns momentos difíceis e em férias. Obrigada por ser esse relevante driver na minha trajetória, Jean.

Agradeço ao Jomar, que me ajudou desde o primeiro exame de qualificação até os últimos dias da tese. Suas contribuições como avaliador foram tão construtivas, que você como uma variável que poderia atuar negativamente no meu progresso por ser meu examinador, me fortaleceu. Jomar, agradeço especialmente por contribuir na minha formação de forma tão horizontal e me fazer acreditar que você estava no meu time. Não posso deixar de agradecer por você ter me recebido na sua casa e no seu trabalho, quando eu estava no clímax da minha tese. Essa visita foi essencial para eu ter a paciência e perseverança necessária para concluir a tese. Obrigada pela coorientação e pelas indagações sobre o trabalho, o que me permitiu trabalhar minha segurança e independência.

Agradeço aos membros do meu comitê de acompanhamento, que ao longo desses quatro anos estiveram acompanhando meu processo de formação. Obrigada Simone, Leandro e Michael. A cada reunião reunida com vocês me senti como parte de uma comunidade científica, onde fui capaz de discutir meu projeto com outras cabeças de contextos distintos e complementares.

Agradeço a Roze, ao Alê Adalardo e novamente ao Jomar pelas contribuições ao primeiro capítulo e na minha formação durante o exame da qualificação. A rejeição naquele momento foi uma das maiores que já havia enfrentado, mas compreendo que esse evento só permitiu obter mais resiliência a futuros e talvez piores rejeições que poderiam vir.

Agradeço a comunidade lepaquiana, desde os primórdios e ao recémchegados. Me orgulho muito de pertencer a esse laboratório. Não digo apenas pela incrível produção científica, o que de fato se destaca por onde passa, mas poder contar com tanta diversidade em áreas de pesquisa, abordagens, trabalhos de campo e cafés. Cada uma dessas situações forneceu elementos para construir um sentimento de pertencimento, pertencimento esse que levarei comigo pra onde eu for.

Agradeço às peças fundamentais do meu doutorado, que com certeza realizaram muito mais do que deveria para eu concluir minha tese. Obrigada Welington por dar todo o auxílio operacional de trabalho no laboratório, com tanta atenção e preocupação. Agradeço a Vera pela enorme empatia e dedicação em me ajudar em todas as fases do doutorado. Seu carinho dá o sopro de energia que muitas vezes 
precisamos, além de nos dar a segurança de que tudo correrá bem. Por último agradeço ao Glauco e Paulo Inácio, que como coordenadores do programa de pós-graduação, permitiram a experiência de realizar uma pós-graduação num ambiente rico e auspicioso. Obrigada também pela atenção e preocupação ao longo do processo.

Aumentando a escala, agradeço aos amigos que encontrei na Eco, por meio de participação de comissão do EcoEncontros e EcoEscola, que me permitiram crescer pessoalmente e profissionalmente. Agradeço a oportunidade de conviver com vocês e conhecer a diversidade de temas e contextos e aprender com isso. Agradeço ao Instituto de Biociências e a Universidade de São Paulo, por promover todo o suporte necessário para eu realizar minha pesquisa e formação, desde de disciplinas até ao incrível CEPEUSP essencial para manutenção da minha saúde mental.

Agradeço a oportunidade de realizar um ano de trabalho de campo, por ele ser como planejei e por ele ter sido tão bem sucedido. Primeiramente agradeço a todos os proprietários, que me deram permissão para realizar minha pesquisa. Agradeço às pessoas que me ajudaram em campo, sem elas o campo com certeza não teria tão bom desempenho, certamente. Obrigada Renê, Cido, Rodrigo, Chico, Adrian, Monte e Thiago pelo trabalho em equipe e companhia.

Agradeço a CAPES pela concessão da minha bolsa de doutorado, obviamente sem ela não seria possível me formar. Agradeço a FAPESP por fomentar integralmente meu trabalho de campo e auxiliar todas as viagens que fiz, apresentando em congressos. Financeiramente também agradeço a Associação Latino-Americana e Internacional de Ecologia de Paisagens, que por meio de auxílios de viagens, tornaram a ida ao Chile e Itália mais possível. Poder ver investimento em ciência e na formação do cientista ainda é uma das coisas que me dá esperança de um mundo melhor. Espero e luto que isso perdure e não se perca por governantes ignorantes.

Agradeço mais uma vez aos meus amores do Hand Barango, que se trata de uma das maiores representações de trabalho de equipe que já vi até aqui. E não somente por tratar de um esporte coletivo, mas porque conta com muita amor, compreensão e companheirismo de mulheres incríveis! Obrigada por sempre me receberem de braços tão abertos.

Gostaria de agradecer a algumas pessoas que não são do meu laboratório, mas senti profunda conexão e sensação de pertencimento. Obrigada sopita, por cruzar o meu caminho e me fazer enxergar a mulher forte que sou, 
com tanto cuidado e atenção. Me espelho muito em ti. Obrigada Solimary por ser um pote de ouro depois do arco-íris, você emana amor e a expressa de muitas formas, sou muito grata por captar teus raios de sol. Obrigada Dieguito de mi corazón por ser esse brigadeiro que és e por ter chegado nos últimos segundos da tese e ainda assim ser esse parceiro maravilhoso, sempre reforçando o que sou e onde cheguei.

Agradeço ao time do carbono e wannabe, que virou noix. Nati, Ka e Chico, foi muito contar com vocês como grupo e individualmente. Com vocês eu aprendi a me relacionar com diferentes níveis de distância e ainda assim de uma forma tão bela e profunda. Obrigada também a todos as companhias de viagem a congresso. Contar com a parceria em viagens que vão além dos próprios congressos é uma dádiva e permitiu compartilhar tantas experiências e lugares novos com pessoas tão incríveis.

Agradeço a minha família por todo apoio até aqui. Por acreditarem em mim e por demonstrar tanto apoio e admiração em cada conquista. Obrigada pai, por me toda paciência e segurança pra eu conseguir realizar meus sonhos e chegar aonde cheguei. Sei que você faz isso por mim e pela mãe. Agradeço também a parte da minha família baiana a qual me reconectei recentemente, mas me senti como desde sempre parte. A agregação de dados da Bahia não poderia ter sido tão rica a tese e a mim.

Agradeço às minhas amigas da infância, Ju e Rê e todos os bibolas da graduação que mesmo não estando tão próximos, ajudaram pontualmente e de forma tão intensa a fortalecer minhas raízes. Agradeço ao Renê por todo companheirismo na concepção desse projeto e no início dele. Essa parceria foi essencial para eu iniciar esse novo caminho e perseguir meus sonhos e planos. Obrigada por tamanha paciência e compreensão. Agradeço também a sua família por ter me recebido como integrante da família e me dar tanto afeto e amor, obrigada Zezinho, Ro e Belle. Levo esse amor comigo.

Agradeço a família que fiz compartilhando morada. Vocês transformaram uma casa num verdadeiro lar. Obrigada Eric, Maria e Adrian por todos momentos partilhados na nuestra casita em diferentes momentos! Obrigada por todo suporte, paciência e amor. As lindas plantinhas de casa só são reflexos dessa energia. Agradeço especialmente ao Adrian por ser meu companheiro de casa, laboratório, viagens - literais e figurativas. Aprender contigo, seja com os meus ou seus problemas, e poder partilhar as pequenas e grandes coisas da vida me enche a alma. 
Agradeço ao Andrés pelo apoio e suporte à sua maneira. Obrigada por pelo companheirismo em tanto momentos lindos e felizes, como nos perrengues de trampar de madrugada no IB e deadlines tão próximos. Conhecer-te foi um dos grandes presentes da minha vida, obrigada por esse encontro e por permitir que perdure mesmo com as adversidades.

Agradeço a todas as paisagens que serviram de inspiração para tese. Elas vão desde vista da sacada da casa de campo na Cantareira e quintal de casa com o Kal em Caraíva até floresta Amazônica, Cordilheira dos Andes e Dolomitas. Foram muitos ecossistemas visitados durante essa tese e acredito que essa heterogeneidade foi essencial na exploração de tanta variação espacial dos dados.

Provavelmente devo ter esquecido o nome de alguém aqui, mas sabia que sou grata ainda assim. Penso que a gratidão é um exercício diário e sou grata a cada momento que vivi. Muito obrigada, gente! 


\section{Índice}

$\begin{array}{ll}\text { Resumo } & 10\end{array}$

Abstract 11

Introdução geral 12

Capítulo 1: "Inverted edge effect pattern on carbon stocks in secondary tropical forests"

Abstract $\quad 21$

1. Introduction $\quad 22$

2. Methods 25

3. Results $\quad 37$

4. Discussion 38

5. Conclusion 42

References 43

Tables and Figures $\quad 50$

Capítulo 2: "Landscape effects overtake abiotic and age influences on forest biomass in tropical fragmented landscapes"

Abstract

1. Introduction $\quad 68$

2. Methods $\quad 72$

3. Results

4. Discussion $\quad 78$

5. Conclusion $\quad 80$

References $\quad 82$

$\begin{array}{ll}\text { Figures } & 90\end{array}$

Capítulo 3: "Contrasting edge effects over successional stages in secondary tropical forests"

Abstract $\quad 94$

1. Introduction $\quad 95$

2. Methods 98

3. Results 106

4. Discussion 112

References $\quad 115$

Conclusão geral 120

Referências bibliográficas da introdução e conclusão geral 124 


\section{Resumo}

O desmatamento e a fragmentação nas paisagens florestais tropicais promovem mudanças na estrutura da paisagem, em geral com perda de florestas antigas para a agricultura ou pastagem, parcialmente compensada com a regeneração das florestas secundárias jovens. Tal processo gera paisagens heterogêneas, com florestas secundárias em diferentes estádios de sucessão e perturbação. 0 estoque de carbono nestas florestas pode, assim, variar muito e essa variação pode ocorrer em diferentes escalas espaciais. Esta tese explora essas variações no nível da paisagem, procurando entender como fatores da paisagem, como cobertura florestal e distância da borda modulam o estoque de carbono, considerando em particular seus efeitos em florestas maduras (em processo de fragmentação) e em florestas jovens. Trabalhamos com dados LiDAR (Light Detection And Ranging) de alta resolução espacial, obtidos em florestas secundárias da Mata Atlântica em duas regiões com condições contrastantes de paisagem: na serra da Cantareira, no sudeste do Brasil, onde a floresta foi intensamente perturbada e fragmentada, e no Parque da Serra do Conduru, no nordeste do Brasil, onde a cobertura florestal ainda predomina. Os resultados indicam que florestas secundárias tropicais de paisagens antropizadas possuem baixos valores de estoque de carbono em comparação com outras florestas tropicais. Além disso, existe uma alta heterogeneidade espacial, guiada principalmente por fatores da paisagem e locais, como perturbações antrópicas. De forma inédita, mostramos que florestas maduras e jovens respondem de forma oposta à proximidade da borda florestal: em florestas maduras, a biomassa é mais baixa na borda do que no interior, conforme relatado por outros autores anteriormente, porém nas florestas jovens, esse efeito é positivo, com maior biomassa na borda do que no interior do fragmento. 0 padrão de borda invertida é possivelmente devido ás condições do microambiente da borda (por exemplo, como alta radiação solar incidente, recrutamento de sementes de árvores e disponibilidade de nutrientes por fertilização agrícola), que poderia promover a regeneração de florestas jovens. Esse efeito invertido de borda em florestas jovens ainda não havia sido descrito para florestas tropicais. Tendo em vista as implicações globais da intensa fragmentação florestal para os processos ecossistêmicos, trabalhos como esse que quantificam os efeitos da paisagem, e em particular das bordas, sobre a biomassa são essenciais para projeções climáticas e de estoque de carbono. 0 presente trabalho contribui para o melhor planejamento de paisagens tropicais em relação ao estoque de carbono florestal. Ações que promovam o aumento da cobertura florestal através da regeneração ou restauração ao redor de florestas maduras podem evitar uma maior perda de biomassa em florestas nativas mais antigas, além de promover um rápido acumulo de carbono nas florestas jovens. Concluindo, nossos resultados sugerem que os estoques de carbono em paisagens antropizadas e fragmentadas podem ser altamente afetadas pela estrutura da paisagem, e particularmente que as condições das bordas podem favorecer o sequestro de carbono nas fases iniciais de regeneração de florestas tropicais.

Palavras-chave: Florestas secundárias, Biomassa, Mata Atlântica 


\section{Abstract}

Deforestation and fragmentation in tropical forests result in changes in landscape structure, with old forest losses for agriculture or pasture, partially offset with the regeneration of younger secondary forests. This process generates heterogeneous landscapes, with secondary forests in different stages of succession and disturbance. The carbon stock in these forests can thus widely vary at different spatial scales. This thesis investigates these variations at the landscape level, seeking to understand how landscape factors, such as forest cover and edge distance, modulate the forest structure and carbon stock, considering both its effects on older forests (in the process of fragmentation) and younger forests. We worked with LiDAR (Light Detection And Ranging) data to obtain canopy height information and carbon stock of secondary forests of the Atlantic Forest in two regions with contrasting landscape conditions: in the Cantareira region, southeastern Brazil where the forest was intensely disturbed and fragmented, and; in the Parque do Serra do Conduru, in northeastern Brazil, where forest land cover still predominates. The results indicated that tropical secondary forests of anthropic landscapes have low values of carbon stock compared to other tropical forests. In addition, there was a high spatial heterogeneity, guided mainly by landscape and local factors, such as anthropic disturbances. Unexpectedly, we found opposite responses of older and younger forests to the proximity to the forest edge: in older forests, biomass was lower at the edge than in the interior, as reported by previous studies, but in younger forests, this effect is positive, with higher biomass at the edge than in the interior of the forest patch. The inverted edge pattern is possibly due to edge's microenvironment (e.g. as high incident solar radiation, tree seed recruitment and nutrients availabity by agriculture fertilization) which could promote the regeneration of young forest. To the best of our knowledge, this is the first time a scientific research describes this inverted edge effect on younger forests. Given the global implications of intense forest fragmentation for ecosystem processes, studies that quantify the effects of the landscape structure, and particularly of the edges, on biomass are essential for climate and carbon stock projections. The present study contributes to a better planning of tropical landscape management in relation to its potential to stock forest carbon stock. Actions that promote increased forest cover through regeneration or restoration surrounding remnant forests may prevent further biomass loss in older native forests, as well as promote rapid carbon accumulation in younger regenerating forests. In conclusion, our results suggest that carbon stocks in anthropogenic and fragmented landscapes can be highly affected by landscape structure, and particularly that edge conditions can favor carbon sequestration in tropical forest at initial stages of regeneration.

Keywords: Secondary forests, above-ground biomass, Atlantic forest

\section{Introdução geral}


2 formações que mais têm sofrido com essa intensa transformação ao longo

3 dos últimos anos (Achard et al., 2002). Aproximadamente mais de $60 \%$ das

4 florestas encontra-se ocupado por paisagens agrícolas ou urbanas do que

5 por paisagens naturais (Reinmann \& Hutyra, 2017) e mais da metade da

6 cobertura restante é composta de florestas secundárias em diferentes

7 estágios de regeneração natural (Poorter et al., 2016). 0 desmatamento para

8 uso agrícola e de pastagens é o principal motivo dessa conversão.

9 Consequentemente, as florestas remanescentes encontram-se altamente

10 fragmentadas: 70\% estão situadas a menos de $1 \mathrm{~km}$ da borda com uma área

11 de uso antrópico (Remy et al., 2016) e 20\% nos primeiros 100 m (Haddad et al., 2015). Os efeitos diretos e indiretos das condições microclimáticas nessas florestas fragmentadas e o intenso regime de perturbação antrópica nas bordas de florestas são apontadas como responsáveis por aproximadamente $10 \%$ da redução de estoque de carbono em florestas tropicais (Chaplin-Kramer et al., 2015), alcançando valores de redução de 50\% nos primeiros 100 metros na Floresta Amazônica (Laurance, 1997). vegetação, também pode contribuir para explicar as mudanças nos estoques de carbono (Brown e Lugo, 1990). A interação entre fatores que agem na escala da paisagem (ou seja, que consideram o espaço no entorno das bordas, como a cobertura florestal, tipo de matriz, e mesmo o efeito de borda) e o regime de perturbação humana também é assim esperada na 
1 regulação do carbono em paisagens secundárias antropizadas. A topografia,

2 por exemplo, pode atuar como um fator limitante para o acesso humano,

3 uma vez que florestas localizadas em encostas íngremes devem ser menos

4 degradadas devido à dificuldade de acesso humano. Consequentemente,

5 esses locais são mais desafiadores para a remoção de árvores, levando à

6 persistência de grandes árvores e maior biomassa acima do solo na

7 paisagem (Becknell et al., 2018). Esses padrões foram previamente

8 observados na Mata Atlântica Brasileira (Silva et al. 2007; Vieira et al.,

9 2011). Apesar da relevância desses fatores para uma melhor compreensão

10 da dinâmica do estoque de carbono em paisagens dominadas pelo homem e,

11 consequentemente, para um melhor gerenciamento de paisagens

12 fragmentadas para enfrentar as mudanças climáticas, a importância relativa e a interação entre esses fatores ainda são pouco compreendidas.

Os processos que agem na regulação do estoque de carbono florestal se inserem no contexto dos processos descritos acima, podendo variar muito em paisagens antropizadas e essa variação pode ocorrer por efeitos em diferentes escalas espaciais e temporais. Fatores abióticos, como o clima e o relevo, atuam sobre o acúmulo de carbono em escala regional, enquanto perturbações humanas influenciam diretamente o estoque de carbono em escala local. Entre estas duas escalas espaciais, os efeitos da dinâmica da paisagem, por meio da fragmentação e desmatamento, também atuam sobre o manutenção do carbono em paisagens antropizadas. No entanto, a importância relativa destes fatores atuando na estrutura florestal é mal 
1 compreendida, apesar da relevância deste conhecimento para uma melhor

2 compreensão do estoque de carbono e, assim, para uma melhor gestão das

3 nossas paisagens para enfrentar as mudanças climáticas.

As florestas tropicais são responsáveis por grande parte do estoque mundial de carbono terrestre (Falkowski et al., 2000; Vieira et al., 2008), por isso, as mudanças na composição e estrutura das florestas tropicais têm sido apontadas como uma das principais causas do aumento da concentração de gás carbônico na atmosfera, e por consequência, como um dos principais vetores das mudanças climáticas globais (IPCC, 2018). Por outro lado, mais da metade das florestas tropicais nativas são florestas jovens, grande parte em estágio inicial de sucessão florestal (FAO, 2017), e estas possuem altas taxas de captura de carbono atmosférico, com potenciais consequências para o ciclo global de carbono (Grace et al., 2014). Tendo em vista a contínua fragmentação em florestas tropicais, o efeito de borda atuará como um importante papel na limitação das estimativas de estoque de carbono terrestre e sua relação com a regulação climática (Reinmann \& Hutyra et al., 2017). Embora as respostas estruturais das florestas à fragmentação, como crescimento, mortalidade e recrutamento à criação das bordas, possuem padrões espaço-temporalmente dinâmicos, a maioria das observações de biomassa e estoque de carbono em bordas florestais são baseadas em bordas estáticas, ou seja apoiada na resposta da floresta num único momento no tempo (Smith et al., 2018). Além disso, essas abordagens não foram delineadas para capturar os efeitos das adjacências, como diferentes 
1 tipos de matriz e perturbações antrópicas, como corte seletivo, abertura de

2 trilhas e entrada e gado (Smith et al., 2018).

3

4

5

6

7

Nesse contexto, precisamos urgentemente entender melhor os processos de recomposição e resiliência de biomassa em florestas altamente

fragmentadas (Poorter et al., 2016). Taxas de regeneração florestal são altamente variáveis e os condutores dessa variação são escassamente compreendidos, o que torna muito difícil a modelagem de estoque de carbono com os dados disponíveis (Norden et al., 2015). Além disso, precisamos de fontes de dados e análises que nos forneçam informações em escala regional e com alta resolução espacial. Os estudos com cronosequências, muitas vezes baseados em um pequeno número de parcelas, não conseguem capturar a variação de biomassa em relação às condições da paisagem (Becknell et al., 2018). Embora estes estudos sejam cruciais para mensurar muitas variáveis locais importantes como densidade de espécies e propriedades do solo, abordagens em extensões territoriais mais extensas, utilizando dados espaciais com alta resolução, como os dados LiDAR (do inglês, Light Detection and Ranging), possibilitam a quantificação da cobertura e regeneração em largas escalas espaciais e com alta definição (Leitold et al., 2015; Becknell et al., 2018). Os dados LiDAR fornecem métricas diretas de altura e densidade de dossel, as quais podem ser utilizadas para gerar estimativas de biomassa florestal (Lefsky et al. 2002, Asner \& Mascaro 2014; Becknell et al., 2018). 
2 estimam, por meio de uma base de dados LiDAR, o estoque de carbono em

3 florestas secundárias da Mata Atlântica e procuram entender como a

4 estrutura da vegetação dessas florestas secundárias é modulada pela

5 regeneração e estrutura da paisagem. Em particular, os estudos estão

6 focados em bordas florestais com uma abordagem multi-escalar,

7 considerando fatores da paisagem, como cobertura florestal e distância da

8 borda, além da relação com fatores temporais. A tese aborda esses aspectos

9 em três capítulos:

1. O capítulo 1, sob o título: "Inverted edge effect pattern on carbon stocks in secondary tropical forests", estima o estoque de carbono a partir de dados LiDAR e inventário florestal. A partir disso, realiza uma análise exploratória de como fatores na escala da paisagem (relevo, e características de composição e configuração da paisagem) e na escala local (idade, composição florística e perturbações antrópicas) afetam os estoque de carbono em uma paisagem na região de estudo da Cantareira;

2. O capítulo 2, sob o título: "Landscape effects overtake abiotic and age influences on forest biomass in tropical fragmented landscapes”, tem como objetivo principal quantificar os efeitos dos fatores da paisagem (cobertura florestal e distância da borda na estrutura vegetacional abordada como altura máxima do dossel - considerando também os já 
reconhecidos efeitos do relevo e idade em florestas jovens e maduras nas duas regiões de estudo (Cantareira e Conduru).

3. O capítulo 3, sob o título: "Contrasting edge effects over successional stages in secondary tropical forests", usa a altura máxima de dossel, como indicador de estrutura vegetacional para entender como se dá o efeito de borda em florestas jovens e maduras, utilizando uma abordagem sistemática e pareada nas duas regiões de estudo (Cantareira e Conduru).

O sistema de estudo do presente trabalho é a Mata Atlântica brasileira. Trata-se de uma floresta tropical altamente diversa e ao mesmo tempo altamente ameaçada, visto que sofre níveis sem precedentes de perda de hábitat, além de outras perturbações antrópicas desde o século 16 (Joly et al., 2014). Este é um cenário ideal para aprimorar a compreensão sobre os fatores que modulam os estoques de carbono em florestas tropicais de paisagens antropizadas (Metzger, 2009; Tabarelli et al., 2010). Hoje em dia, esta floresta está reduzida a cerca de $28 \%$ de sua distribuição original (Rezende et al., 2018; Figura 1), com a maior parte dos fragmentos florestais remanescentes sendo reduzida a pequenos fragmentos, com menos de 50 ha (Ribeiro et al., 2009). Cerca de 46\% dos remanescentes encontram-se a menos de 100 m da borda (Ribeiro et al., 2009). A Mata Atlântica ainda sofre com a expansão de diversos cultivos, como a cana-de-açúcar e o eucalipto, além da expansão das áreas urbanas e da ampla ocupação por áreas de pastagem (Ribeiro et al., 2011). Atualmente, cerca de 120 milhões de 
1 pessoas vivem na área original da Mata Atlântica, boa parte em áreas

2 urbanas de grande porte (Tabarelli et al., 2010). Dentro do domínio Mata Atlântica, duas regiões de estudos,

4 Cantareira, no estado de São Paulo (Cantareira) e a Serra do Conduru na

5 Bahia (Conduru), foram selecionadas. Essas duas regiões apresentam

6 condições contrastantes de paisagem, as quais nos permitem explorar o

7 efeito de distintos contextos em relação aos processos que modulam

8 regeneração florestal. Cantareira é menos florestada, com apenas cerca de

$920 \%$ de vegetação nativa, e intensivamente perturbada, enquanto que

Conduru possui aproximadamente $80 \%$ de cobertura de vegetação nativa, além de sofrer menos com perturbações antrópicas atualmente. Em relação a proporção de florestas em estágio inicial de sucessão (aqui definida como sendo com menos de 28 anos), a Cantareira é composta por cerca de 5\% de florestas jovens, enquanto que esse valor não chega a $1 \%$ no Conduru.

A Cantareira (Figura 1C, 1D e 1F) é um importante corredor ecológico, considerado como de alta prioridade para conservação da biodiversidade no estado de São Paulo (Rodrigues et al., 2008; Joly et al., 2010). As paisagens nessa região são muito heterogêneas e compreendem diferentes tipos de uso de solo antrópico, sendo majoritariamente composto por campos antrópicos em pequenas propriedades e silvicultura, principalmente Eucalyptus spp. Os remanescentes de vegetação nativa estão em propriedades particulares e estão submetidos a diferentes níveis de 
1 perturbação (Whately and Cunha 2006). 0 Conduru (Figura 1B e 1E) é uma

2 área de Parque estadual, que está sobre proteção há mais de 20 anos. Essa

3 região é uma das maiores áreas contínuas de Mata Atlântica do Nordeste

4 brasileiro. Compreende manchas de florestas secundárias em diferentes

5 estágios de regeneração, áreas com restauração ativa e áreas remanescentes

6 que sofreram corte seletivo no passado. Além do corte seletivo, outras

7 atividades como caça e exploração de fibra vegetal foram relativamente

8 comuns no passado (Piotto et al., 2009). Além disso, existem áreas de

9 pastagem, estradas de terra e algumas trilhas utilizadas pela comunidade

10 local dentro do parque (Becknell et al., 2018).

11 Esperamos com essa tese expandir nosso conhecimento sobre como

12 processos que operam no nível da paisagem afetam (em interação com

13 outros fatores, ligados ao relevo e às perturbações humanas) a regulação de

14 biomassa em paisagens florestais tropicais, considerando em particular o

15 efeito de borda em florestas com diferentes idades. 

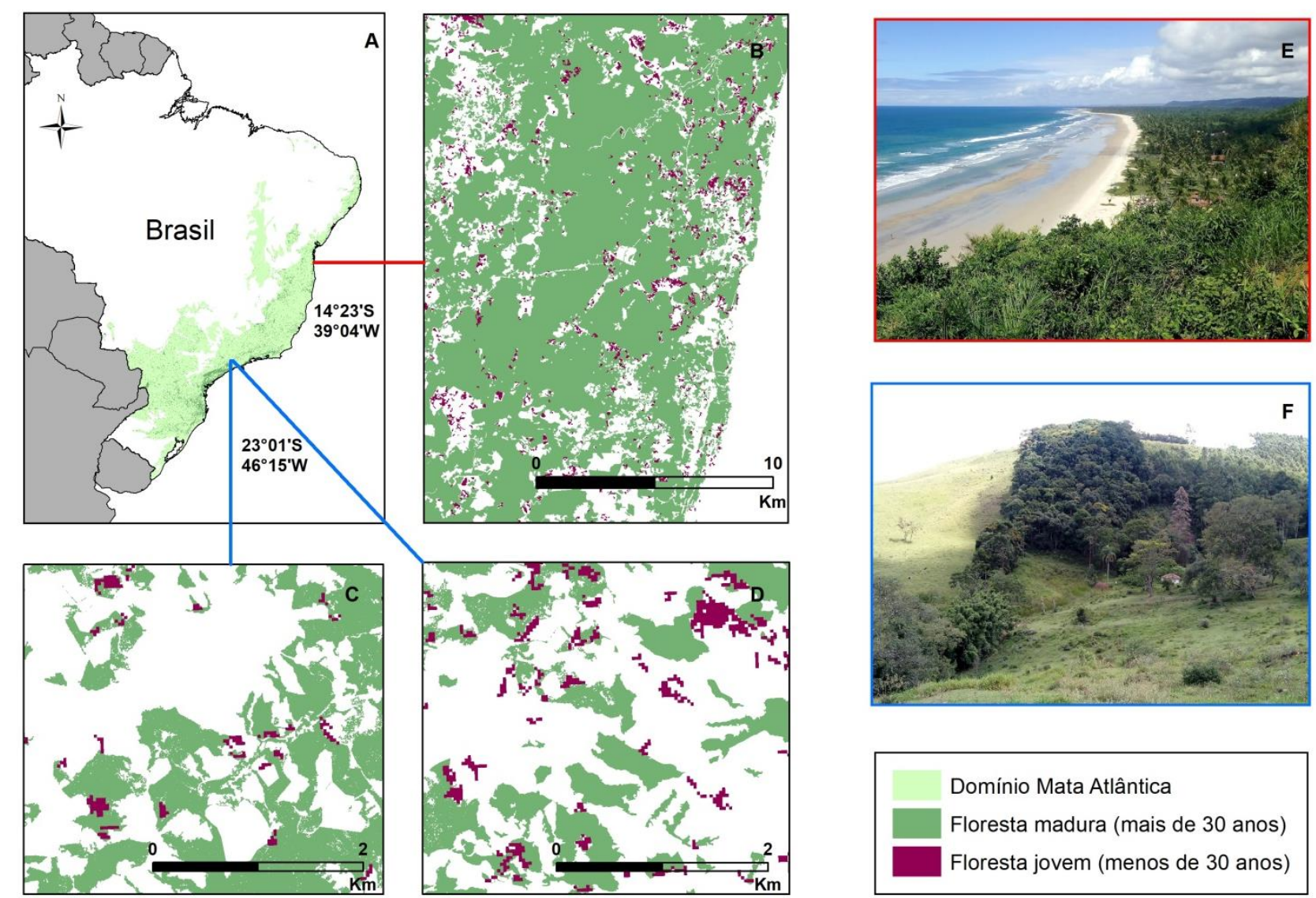

Domínio Mata Atlântica

Floresta madura (mais de 30 anos)

Floresta jovem (menos de 30 anos)

2 Figura 1. Representação do domínio Mata Atlântica a distribuição de florestas maduras (mais de 30 anos) e florestas jovens 3 (menos de 30 anos). Os painéis $\mathrm{B}$ e E representam a área de estudo do Conduru e os painéis C, D e F representam a área de 4 estudo da Cantareira. 
1 Capítulo 1: "Inverted edge effect pattern on carbon stocks in secondary

2 tropical forests"

3 Isabella Romitelli, Jomar Magalhães Barbosa, Rodrigo Trassi Polisel, Michael

$4 \quad$ Keller and Jean Paul Metzger

5 ABSTRACT

Although the importance of tropical forests to regulate greenhouse gases is well documented, little is known about what factors affect the ability of secondary forests to store carbon in human-dominated landscapes. Among those factors, landscape structure, forest disturbance, and topography aspects can have important roles. Here, we evaluated, using field and LiDAR (Light and Detection and Ranging) data, how landscape effects (composition, configuration, and terrain) affect directly forest carbon stock in human-dominated landscapes from the Brazilian Atlantic forest. At the site level, we also explored directly how landscape effects affect local vegetation composition and structure which in turn affect carbon stock, as well such factors affects carbon stock. The study area showed a relatively low carbon stock (45.49 $\pm 9.34 \mathrm{Mg}$ ha-1) when compared with other Atlantic forest regions. At landscape level, the interaction between forest cover, edge effect and slope was the best combination of explanatory variables for carbon stock. Although carbon stocks were low both at the edges and interior of the studied secondary forest fragments, we found carbon stock to be higher close to the edges. This unexpected edge effect contradicts the usual pattern reported in the literature for old growth forests. We argue this pattern is related with a positive effect that microclimatic conditions in the edge can have stimulating forest regeneration, as we tested at plot level which edge distance and floristic composition, mainly shade-tolerant species proportion, affect carbon stock. These results suggest that carbon stocks in human-dominated and fragmented 
1 landscapes can be highly affected by the landscape structure, and particularly that edges conditions can favor carbon sequestration in regenerating tropical forests.

Keywords: tropical forests, fragmented landscapes, above-ground biomass, Atlantic forest, lidar

\section{Introduction}

Tropical forests have undergone an intense transformation over the last few years (Achard et al., 2002) mainly due human activities, such as logging, hunting, agricultural expansion, and human settlement (Giam, 2017). Currently, about 50\% of tropical and subtropical forests have already been fully converted to non-forest areas (Sanderson et al., 2002; Hoekstra et al., 2005), and more than half of the remaining cover is composed of secondary forests at different stages of natural regeneration (Poorter et al., 2016). The consequence of this transformation is not only the loss of biodiversity (Chapin et al., 2000) but also a reduction in the provision of different ecosystem services, including the capacity of those forests to capture and stock carbon and thus to mitigate climate change (Berenguer et al., 2014). Although the importance of tropical forests to regulate greenhouse gases is well documented (e.g. Bonan, 2008; Pan et al., 2011), there are some knowledge gaps of how local- and landscape-level factors interact to affect the ability of tropical forests to store carbon in human-dominated landscapes (Laurence et al., 1997; Melito et al., 2018; d'Albertas et al., 2018; Romitelli et al., in prep.). Localand landscape-level factors, e.g. species composition, forest age, landscape composition, terrain and human impact, may have large implications on forest 
1 degradation and regeneration, and thus can impact the temporal dynamic and

2 spatial distribution of carbon stock.

Forest areas located near edges receive more insolation and are usually hotter and drier and are more exposed to wind effects when compared to the forest interior (Laurance et al., 2011). As consequence, tree species composition is strongly affected by microclimatic changes in forest edges, as well by floristic and functional simplification induced by edge creation (Lôbo et al., 2011; Michalski et al. 2007). In particular, forest edges with contrasting or open matrix, such as crops or pasturelands, have higher mortality of large trees (Laurance et al., 1997; D'Angelo et al., 2004) and higher dominance of initial successional species (Laurance et al., 2011), potentially resulting in lower carbon stock on forest edges as compared to non-fragmented primary forests (Laurance et al., 2001). In addition, landscapes with severe forest fragmentation and large forest-edge extension could tend to store less carbon than landscapes with the same amount of forest where fragments are bigger and more compact (Pütz et al., 2011). The combined influence of adjacent edges can also intensify ecological changes in comparison to what would be expected from a single forest edge (Ries et al., 2004). Overall, it is expected that landscapes with less amount of forest, more contrasting matrix and more abundant edges will have less carbon stock (Melito et al., 2018). Additionally, different abiotic conditions, generally related to terrain, soil, and climate, can alter forest regrowth as well as the distribution of big trees on the landscape (Castilho et al., 2006), and thus can modulate carbon 
1 accumulation. Although the above-mentioned processes are expected for primary 2 and older forests, we know very little how the forest edges determine landscape-

scale carbon stock in secondary forests with different stages of natural regeneration. The microclimate conditions near to the edge could promote the regeneration while increasing the light availability for photosynthesis.

The history of human disturbance, which affects the vegetation structure, can also contribute to explain changes in carbon stocks (Brown and Lugo, 1990). The interaction between landscape-level factors (i.e. forest cover, matrix type, edge effect) and human disturbance is also expected. Topography, for example, may act as a limiting factor for human access as forests located on steep slopes are expected to be less degraded due to the difficulty of human access and consequently those places are more challenging to remove trees, persisting large trees standing and more aboveground biomass in the landscape (Becknell et al., 2018). These patterns have been observed in the Brazilian Atlantic forest (Silva et al. 2007; Vieira et al., 2011). Despite the relevance of those factors for a better understanding of the dynamics of carbon stock in human-dominated landscapes, and consequently for better management of fragmented landscapes to face climate change, the relative importance and the interaction among those factors are poorly understood.

Using field and LiDAR (Light and Detection and Ranging) data, here, we evaluated how landscape and local conditions affect directly and indirectly carbon 
1 stock from the Brazilian Atlantic forests in different growth stages and located at a

2 human-dominated landscape. We expect that landscape composition,

3 configuration and terrain interact with local-level factors (forest age, edge

4 distance, human disturbance) to determine vegetation composition and structure

5 (floristic composition, shade-tolerant species proportion and mean wood-

6 density), which in turn affect carbon stock (Figure 1). This is one of the few

7 studies that estimate carbon stock in Atlantic secondary tropical forest with high-

8 resolution LiDAR data, allowing analyses at both site and landscape levels. Due to

9 its large extent and long history of deforestation, fragmentation, and current

10 regeneration process, the Brazilian Atlantic forest is an ideal system to improve

our understanding on the landscape factors that modulate carbon stocks in tropical secondary forests (Metzger, 2009; Tabarelli et al., 2010).

\section{Methods}

To understand how landscape and local conditions affect directly and indirectly carbon stock, we performed two different carbon stock calculations: a site level estimation by allometric models of above-ground biomass and; a landscape level estimation using LiDAR models. As well, we performed the explaining carbon stock spatial distribution at two levels: landscape and local level. The influence of landscape and local conditions was performed by model selection with all possible combinations of two variables (with and without interaction), a null model (no effect) and all single models. The landscape 
1 variables were forest and matrix cover, Euclidean and additive edge effect,

2 elevation, slope and aspect. The local variables were forest age, edge distance,

3 human disturbance and floristic composition, shade-tolerant species proportion

4 and mean wood-density.

The landscape and plot-level explaining carbon stock spatial distribution

6 (Figure 1) considered the direct effects of landscape conditions; and composition

7 and structure vegetational conditions on carbon stock and the indirect effects of

8 local conditions on composition and structure vegetational. Thus, we presumed

9 that the carbons stock changes are effect of composition and structure vegetational changes promoted by local conditions.

At landscape level, composition and structure vegetational conditions were not considered due the data absence at this scale. 
1 Atlantic Forest (220 km2 year-1; Soares-Filho et al., 2014), but may reach up to

$2 \quad 2.9 \%$ in the São Paulo metropolitan area (Teixeira et al., 2009).

3 The study region, the Cantareira-Mantiqueira corridor, is located in Southeast

4 Brazil encompassing a wide mountain ridge region responsible for more than

$550 \%$ of the water supply of the city of São Paulo (Cantareira System). This region

6 is not only relevant for water supply but also for biodiversity conservation. It

7 includes an important ecological corridor which was considered of high priority

8 for biodiversity conservation at the state level (Rodrigues et al., 2008; Joly et al.,

9 2010). Landscapes of the Cantareira-Mantiqueira corridor are very heterogeneous, comprising different land uses, mostly pasture areas in small properties and reforestation, especially with Eucalyptus spp. Native Atlantic Forest vegetation, in different successional stages and submitted to different levels of disturbance, represents $21 \%$ of the studied region (Whately and Cunha 2006).

\subsection{LiDAR data}

Our study was performed within an area of 499 hectares, where LiDAR data was acquired in October 2014 for this entire extent by an airborne Optech sensor (Orion, 09SEN243) at an altitude of 853 meters, with a view angle of $10^{\circ}$. Laserspot spacing was maintained at approximately 34.62laser shots m-2. Approximately $43 \%$ of this LiDAR dataset ( $215 \mathrm{ha}$ ) is covered by native forest vegetation (i.e. canopy height above $6 \mathrm{~m}$ with at least 2 strata; Figure $2 \mathrm{~A}$ ). 
Within the 215 ha of forest remnants observed in the studied area (the LiDAR dataset), 16 plots of $25 \times 25$ meters in size were sampled, totaling 0.9 ha. This plot size is smaller than plots usually used in similar studies in the Amazonian forest (e.g. Espirito-Santo et al., 2014; Andersen et al., 2014; Hunter et al., 2015; Chen et al. 2016; Jucker et al., 2017), however, the plot size in our study was consistent with the high spatial resolution of the LiDAR data and it was defined in order to be the largest size without including an excessive vegetation composition and structural heterogeneity. Because the studied landscape presents a high spatial heterogeneity in forest regrowth stages (Romitelli et al., submitted), the number of plots was defined to sample different vegetation conditions.

The location of plots was defined following a random-stratified sampling protocol. First, we created two LiDAR images using two LiDAR metrics: (1) maximum canopy height within the $95 \%$ of the vertical LiDAR pulse return, disregarding outliers (5\% of the higher pulses returns); and (2) relative laser pulses density returns in the 0 to 5 meters strata. The maximum height is a good predictor of tree growth (Wasser et al., 2013), while the relative density of returns is a good proxy of forest disturbance and occurrence of trails created by human or livestock (D'Oliveira et al., 2014). Consequently, we used both metrics in the sampling selection to represent the canopy structure heterogeneity and allowing the identification of clearings and trails. In total, we created four classes of 
1 maximum height $(0-14 \mathrm{~m} ; 15-17 \mathrm{~m} ; 18-20 \mathrm{~m} ; 21-37 \mathrm{~m})$ and other four class of

2 relative density of returns $(0-0.35 ; 0.36-0.46 ; 0.47-0.56 ; 0.57-1)$, resulting in 16

3 classes. In each class, one field plot was located randomly but always depending

4 on access permission from landowners.

\subsection{Field carbon stock}

In each plot, we conducted a field inventory between December 2016 and April 2017. The plot location was defined using a geodesic GPS (TOPCON Hyper SR) and

Station Total Geodetic NTS-325, which allowed spatially accurate measurements, with an estimated error of 2-5 centimeters.

We measured all individuals with a diameter at breast height (DBH) higher than $4.8 \mathrm{~cm}$. The diameters were measured at $1.3 \mathrm{~m}$ height (DBH) of all live stems, including trees, palms, tree ferns, lianas, and standing dead trees and palms. The tree height was estimated using a Leica DISTOtm A5 laser distance meter. We identified around $90 \%$ of the individuals at the species level, while the remaining individuals were classified at the genus level (Table S1).

We applied different allometric equations to the field inventory measurements to calculate plot-level above-ground biomass (AGB) and carbon stock. For palms and lianas, we used allometric equations from Goodman et al. (2013) and Schnitzer et al. (2006), respectively. For living trees, we use the allometric equation for tropical forests of Chave et al. (2014) with DBH, height and wood density. To determine the wood density we utilized the database from Chave et al. 
1 (2014) and Alves et al. (2010). To standing dead trees, we combined the taper

2 function for volume (Chambers et al. 2000) and the void-corrected snag density

3 from Palace et al. (2007). The conversion of above-ground biomass to carbon

4 stock follows Martinelli et al. (2000).

\subsection{Landscape carbon stock}

In the carbon mapping approach, we applied the equation produced by

7 Becknell et al., 2018 (equation 1) to our LiDAR data. Because this equation was produced for the same vegetation type (i.e. Brazilian Atlantic forest) and there are important similarities between study areas, we assumed acceptable the transferability of the equation 1 to our study zone. We understand some limitations may occur on this approach, increasing errors in carbon estimations. However, transferability of LiDAR-based carbon equations among study regions has been largely proven to be acceptable in different studies (adicionar referencias aqui). Becknell and collaborators (2018) compared linear and sigmoidal models using automated variable selection algorithms and used the Akaike information criterion (AIC) to select the best equation. The following equation showed the smallest RMSE (50.45 Mg/ha) and made realistic (nonzero) predictions of biomass density across the landscape: 
1 where, P95 is the height of the 95th percentile (m) of lidar returns over the 0.25

2 ha plotThe final carbon map of the study area with a spatial resolution of $15 \mathrm{~m}$ is

3 shown in Figure 3. This resolution was defined after testing pixels of 5, 10, 20 and

$425 \mathrm{~m}$ (Table S2). The size of $15 \mathrm{~m}$ allowed maintaining a high spatial resolution,

5 avoiding significant spatial autocorrelation (Pearson's $r<0.70$; Zuur et al., 2009).

\subsection{Landscape explanatory variables}

$7 \quad$ Landscape structure

Forest and pasture covers are the predominant land use on this study region (Whately and Cunha, 2006). Pasture was the predominant land use (42\% of the matrix), and thus represents the main inter-forest matrix composition. Therefore, we mapped and calculated the amount of forest and pasture within a buffer zone of $500 \mathrm{~m}$, placed around each pixel of the carbon map (15 x $15 \mathrm{~m}$ ). We tested other landscape extents $(250 \mathrm{~m}, 1 \mathrm{~km}$, and $2 \mathrm{~km})$ and observed that forest cover was highly correlated across spatial scales. We created this moving window approach to evaluate how the surrounding landscape composition affects carbon stock at the pixel level.

In addition, we evaluated the edge effect on local level carbon stocks using two methods. The first method considers additive edge effects of all edge within a predetermined distance from a focal forest pixel (Dmax) (Malcolm, 1994). We called this index the edge effect index and it was already applied to the same study region (see d'Albertas et al., 2018). This index ranges from 0 to infinity, where 
1 higher values mean more edge effect. We implemented the edge effect index

2 model using the R package 'edgefx' (Goldberg and Ries, 2010) in the R statistical

3

4 to the interior of the fragment (i.e. Dmax $=100 \mathrm{~m}$ ) and, additionally, we tested

5 other two Dmax values, 25 and $50 \mathrm{~m}$. We used our forest /non-forest classification map (from the year 2016) to generate raster images of edge effect index for each pixel classified as forest in our study landscape (Figure 2). The second method to evaluated edge effect is a simple measure of the nearest forest edge using the Euclidean distance (straight-line distance between two points), obtained by Spatial Analyst in ArcGIS 10.2 (Figure 2). Both edge effect index and Euclidean distance were calculated with a 15 meters pixel size (the same pixel size of the carbon stock map).

$\underline{\text { Terrain }}$

The elevation, aspect and terrain slope were obtained through topographic maps with 1:50,000 of scale and contour curve of 20 meters provided by the Brazilian Institute of Geography and Statistics (IBGE). From this elevation map, we produced the Digital Elevation Model (DEM), aspect and terrain slope using 3D Spatial Analyst in ArcGIS 10.2. Those metrics were also extracted with a $15 \mathrm{~m}$ pixel resolution. 


\subsection{Analyses at the landscape level}

The carbon stock estimated for each pixel was used as the response

variable and landscape structure and topography were explanatory variables. We then used a generalized linear model with a Gaussian distribution to quantify and model the effects of landscape factors on carbon stock.

Before building the model, we conducted an exploratory data analysis to select only those explanatory variables with a relatively low correlation (Pearson's $r<0.70$; Zuur et al., 2009). Aspect was excluded because it was strongly correlated with the slope $(r=0.80)$. Besides that, the edge effect additive index with DMax= $50 \mathrm{~m}$ was correlated with $\mathrm{DMax}=100 \mathrm{~m}(\mathrm{r}=0.73)$ and with DMax $=25 \mathrm{~m}(\mathrm{r}=0.82)$. Therefore, we only used DMax= $50 \mathrm{~m}$ because this index represents the other two Dmax (25 and $100 \mathrm{~m}$ ).

To reduce the number of variables, we built simple models in order to evaluate the best variable to explain carbon stock variations considering three groups of explanatory variables separately: landscape composition (forest and pasture cover); landscape configuration (Euclidean distance and edge effect index); and terrain factors (elevation, aspect and slope). From this initial evaluation, forest cover, edge effect index, and slope variables were selected to perform further analyses.

To explain the carbon stock, we then considered all possible combinations of two variables (with and without interaction), a model with all variables (with 
1 and without interaction), a null model (no effect) and all single models. We

2 selected the most plausible model among the 12 models tested using the corrected Akaike information criterion (AIC). The AIC is a selection criterion that penalizes models with many parameters with a correction for small sample sizes (Burnham and Anderson, 2002). Small values of AIC represent the best fit, so the model with the lowest value AIC was considered the most plausible and models with $\triangle$ AIC $<2$ were considered equivalent. The statistical analyzes were performed using the R environment (R Development Core Team, 2017).

\subsection{Analyses at the plot level}

In order to explore possible mechanisms that explain carbon stock variation, additional analyses were performed with the 16 field sampled plots. Here, we consider that landscape-level factors are affecting local-level factors, particularly patch shape (and thus edge distance), forest age and human disturbance, and those local factors can affect directly or indirectly the carbon stock. In the direct relationship, carbon stocks respond directly to forest age, edge distance and human disturbance. In the indirect relationship, forest age, edge distance, and human disturbance affect first the forest structure and composition (here represented by the floristic composition, shade-tolerant species proportion, and wood density mean), which then affect carbon stocks (Figure 1). A model selection analysis was performed for each above-mentioned relationship, 
1 following the same method described in item 2.7 but with the adjustment for

2 small samples (AICc).

Forest age was estimated based on aerial photographic surveys conducted

4 by the Brazilian army in 1962 and satellite images captured by LANDSAT TM5 during the years of 1985 and 2006. Considering texture pattern of the photographs and satellite images, we were able to distinguish younger and mature forests. Hence, we considered six forest age classes: more than 80 years (mature forest in 1962 image); 65 years (younger forest in 1962 image); 50 years (mature forest in 1985 image); 40 years (younger forest in 1962 image); and $\sim 20$ years (presence only in 2006). We also measured the plot distance to the closest edge in 1962, 1985, 2006 and 2014 (Figure S1) with the intention to verify the temporal dynamics of this variable.

The degree of human disturbance was evaluated with field data at the plot level. We considered the main forest disturbance types (such as the presence of selective logging, human trails, livestock trails, and forest gaps), and combined the observed level of disturbance with its extent within the plots. Disturbance level and extent (i.e. spatial distribution) were combine in a unique index by multiplying these two values (Table S4). The human disturbances were ranked from 5, very high disturbance (e.g. selective logging), to 2, very low disturbance (e.g. human trails) with their spatial distribution, also ranked from 1, very low spatial distribution (10-20\%), to 5, very spatial distribution (80-100\%) (See table 
1 S4 for a full range of values). We thus obtained a human disturbance index based

2 on disturbance type and extent. If more than one type of disturbance were present

3 within each plot, we summed the human disturbance index, creating a plot-level

4 total disturbance. Although we expect the edge proximity could affect the human

5 disturbance, it is worth mentioning that human disturbances were not correlated

$6 \quad$ with edge distance gradient.

To compare floristic composition among plots, and at different edge

distances and plot-level carbon stock, we used the first axis of a Principal

component analysis (PCA), indicating level of similarity of species identity and abundance at the sampled plots. PCA values near to zero indicate proximity between PCA center or similarity between plots. The PCA ordination was performed using the R environment with the 'vegan' package (R Development Core Team, 2017). Each plot has a PCA value and this value was used as a variable in the model selection.

Wood density mean was considered as a predictor of the successional stage (West et al., 1999; Pooter et al., 2008; McCulloh et al., 2011). We used two related metrics to model the successional stage at the plot-level: i) mean wood density and; ii) proportion of shade-tolerant species. Mean wood density was the average wood density of all individual trees within a plot. Proportion of shade-tolerant species was the proportion of tree individuals with wood density over 0.69 g.cm-3 
1 based on the wood density of shade-tolerant species inventoried in this study (e.g.

2 Machaerium villosum, Copaifera langsdorffii, Maclura tinctoria, Aspidosperma

3 ramiflorum).

\section{Results}

The LiDAR-based estimate of average forest carbon stock in the studied landscape was $45.49 \pm 9.34 \mathrm{Mg}$ ha- 1 , which was very similar to the mean values observed at the plot level inventory (42.67 $\pm 9.24 \mathrm{Mg}$ ha-1; Figure $3 \mathrm{~A})$. At the landscape level, edges and small fragments showed higher carbon stock values than forest interior (Figure 3B). The model with the interaction of all three variables (forest cover, edge effect index, and slope) was the best explanatory model (Table 1). The edge effect index and the forest cover presented a clear positive influence on carbon stock ( $\mathrm{R} 2=0.368$ and $\mathrm{R} 2=0.276$, respectively), while the effect of terrain slope was less evident, but also positive (R2=0.355; Figure 4).

At the plot level, edge Euclidean distance and forest age were the main factors affecting vegetation structure (i.e. floristic composition, shade-tolerant species proportion, and wood density mean; Figure 5 and Table S3). Additionally, forest age influence floristic composition and wood density (Table S3). Human disturbance was related to shade-tolerant species proportion. Edges distance (Figure S2A) and forest age (Figure S2B) have a positive effect on carbon stocks 
$1 \quad(\mathrm{R} 2=0.389$ and $\mathrm{R} 2=0.184$, respectively). Plots near to forest edges in old

2 fragments showed high values of carbon stock.

3 The plots show relative high floristic composition similarity, regarding three

4 plots (Figure S3A). The floristic composition, as well as carbon stock, varied

5 according to the Euclidean distance to the edge, with a clear spatial segregation at

640 meters from the edge (Figure S3B). Plots near to the edge are composed

7 mainly by shade-tolerant species with high wood density (e.g. Actinostemon

8 concepcionis, Casearia sylvestris, Guapira opposite and Machaerium villosum )

9 while plots distant more than 40 meters apart from the forest edge are composed mostly by common pioneers species with low wood density (e.g. Maytenus evonymoides and Trema micrantha).

\section{Discussion}

Carbon stocks in the studied human-dominated landscape are clearly affected by landscape-level conditions, such as forest cover, edge effect, and slope, and also by local-level factors or conditions, particularly edge Euclidean distance, forest age, and human disturbances. Edge effect processes at the local and landscape scales seem particularly important, once they can affect local structural vegetation variables (floristic composition, shade-tolerant species proportion and wood density mean), resulting on an impact on forest carbon stock (Figure 1).

Surprisingly, forest biomass and carbon stock presented an inverted spatial pattern of what is usually reported in the literature: carbon stocks were higher 
1 close to the edges than in forest interior, suggesting an inverse pattern of edge

2 effects. This is the first study showing this unexpected pattern (but see Costa

3 2015). One possible explanation is that in human-dominated landscapes,

4 composed essentially by secondary forests, carbon stocks are globally low, but the

5 recovery of biomass is faster at edges, where there is greater availability of light

6 for photosynthesis. Edge effects may benefit plant community regrowth, favoring

7 a high density of regenerating individuals, including species with high wood

8 density, which consequently result in a faster accumulation of carbon.

The edge effects influence on carbon stock is widely described in the literature (e.g. Laurance et al., 1997; Putz et al., 2014). Melito et al. (2018) performed a systematic literature review and created a conceptual model of landscape-level effects on forest above-ground biomass. According to this model, after stabilization of shade-tolerant species mortality, above-ground biomass may increase by the proliferation of pioneers and lianas, but this effect should be insufficient to compensate losses related to the period of sharp biomass decrease (Melito et al., 2018). However, such effects are predicted for remaining forest affected by surrounding deforestation and fragmentation processes, but not for forest patches regenerating in a fragmented and human-dominated context, which is mostly the case in our study area (a landscape with a long history of human disturbances). 
At our studied sites, forest carbon stocks were explained by the interaction

2 between forest cover, edge effect, and slope. Although terrain factors were already

3 reported as important determinants of carbon stock (Vieira et al., 2011), here they

4 showed quite low influence on carbon stock, compared to landscape

5 compositional and configurational variables. The influence of terrain factors can

6 be potentially masked in human-dominated landscapes, due to a stronger effect of

7 factors directly related to human disturbances (e.g. seedlings suppression by

8 livestock foraging patterns, trails and logging), which are usually supposed to

9 occur more intensively near forest edges (Berenguer et al., 2014). More

10 important, human activities are interacting with landscape structure to determine

11 carbon stocks (Table 1). Terrain slope could be a regulatory variable in human-

modified landscapes because most of the fragmented and secondary forests occur in steepest slope areas (Silva et al., 2007, 2008, Teixeira et al., 2009), which are areas difficult to use as agriculture land (Asner et al., 2009). But apparently in the studied landscapes, human disturbances occur in all areas, both near and distant from edges (Romitelli et al. in prep), and for this reason, disturbances were not a good variable to explain carbon stock variation.

The effect of forest cover on carbon stock was positive. The presence of forest surrounding the study sites positively affects carbon stocks. Beyond the positive contribution of nearby forest fragments to facilitate forest regeneration (Guevara et al., 1992; Guevara and Laborde, 1993; Galindo-Gonzalez et al., 2000), 
1 landscapes with more forest cover are also less densely populated and thus less

2 affected by human disturbances, supporting the accumulation of carbon.

3 The local-level analyses - using only the sampled plots - indicated that carbon

4 stock accumulates faster near to the edge of the fragments (less than 40 meters

5 from the edge), and this pattern was particularly clear for older forests (more

6 than 60 years). The main aspects involved with carbon accumulation in these

7 conditions were explained by a higher density of shade-tolerant species near

8 edges in older forest fragments ( $>40$ years) because the shade-tolerant species

9 (high wood density) contribute substantially to carbon stock (Figure S4). The large trees which greatly affect biomass have already been lost in our study landscapes and in different other Atlantic forest regions (Romitelli et al., 2014; Costa et al., 2015). Consequently, the biomass variation is affected by small variations in species composition (Figure S5), in particular, the proportion of shade-tolerant trees and species with higher wood density.

Our results suggest that carbon variation in landscapes with a long history of human disturbances, where large trees were already lost, cannot follow the general rules observed for remnant fragments in recently fragmented landscapes (Pullin and Stewart, 2006; Koricheva et al., 2013; Melito et al., 2018). Fragments regenerating in fragmented landscapes are accumulating carbon near the edges where photosynthetic activities are more intense. In our case, those areas showed a higher density of shade-tolerant species with higher wood density. However, 
1 further studies are needed to understand how plant community composition

2 change with forest regeneration in different edge conditions. In addition to the

3 factors already mentioned in the conceptual model of Melito et al. (2018; e.g.,

4 patch size, edge distance, matrix type, time since edge creation), we propose here

5 that future studies on carbon stocks in human-dominated landscapes should

6 consider whether the forest is regenerating or being degraded in a fragmented

7 condition. In the first case, regenerating forests can present an inverse pattern of

8 carbon accumulation near edges. If this unexpected pattern repeats world widely,

9 fragmentation can have a surprisingly positive effect on carbon stock in

10 worldwide secondary tropical forests located in human-dominated landscapes.

\section{Conclusion} characterized by low carbon stocks, (high spatial heterogeneity and multiple interactions among landscape and local factors determining carbon stocks. As a consequence, the potential carbon services provided by fragmented tropical landscapes are complex (Melito et al., 2018). To understand the mechanisms affecting carbon stocks, we need to consider the wide variety of factors acting on carbon stock in tropical forests. Particularly, in human-dominated landscapes, biomass accumulation in regenerating forest can be different from those usually observed in existing forest fragments being submitted to degradation processes.

21 In this regard, our findings support programs of ecosystem services payments, 
1 such as REDD+, which financially reward developing countries that reduce

2 emissions from deforestation and forest degradation. Additionally, our findings

3 support differentiated carbon accumulation patterns in human-dominated

4 landscapes, which must be considered in carbon trading agendas (e.g., REDD+)

5 and carbon-conservation initiatives.

\section{Acknowledgments}

We thank all landowners for giving permission to conduct fieldwork on their lands and for the outstanding support. We pleased thank to Cristina BanksLeite and Leandro Tambosi for all suggestions and comments which improved this article. This study was developed within the "Interface Project", supported by São Paulo Research Foundation (FAPESP, 2013/23457-6). I.R. was supported by a doctorate's fellowship from the Brazilian Ministry of Education (CAPES-DS, 20152019).

\section{References}

Achard, F., Eva, H.D., Stibig, H.J., Mayaux, P., Gallego, J., Richards, T., Malingreau, J.P. 2002. Determination of deforestation rates of the world's humid tropical forests. Science 297, 999-1002.

Alves, L.F., Vieira, S.A., Scaranello, M.A., Camargo, P.B., Santos, F.A.M., Joly, C.A., Martinelli, L.A., 2010. Forest structure and live aboveground biomass variation along an elevational gradient of tropical Atlantic moist forest (Brazil). For. Ecol. Manag. 260, 679-691.

Andersen, H.E., Reutebuch, S.E., McGaughey, R.J., d'Oliveira, M.V.N., Keller, M. 2014. Monitoring selective logging in western Amazonia with repeat lidar flights. Rem. Sens. Env. 151, 157-165. 
Asner, G.P., Rudel, T.K., Aide, T.M., Defries, R., Emerson, R. 2009. A contemporary assessment of change in humid tropical forests. Conserv. Biol. 23, 1386-1395.

Becknell1, J.M., Keller, M., Piotto, D., Longo, M., dos-Santos, M.N., Scaranello, M.A., Cavalcante, R.B.O., Porder, S. 2018. Landscape-scale lidar analysis of aboveground biomass distribution in secondary Brazilian Atlantic Forest. Biotropica, 50 (3), 520-530.

Berenguer, E., Ferreira, J., Gardner, T.A., Aragão, L.E.O.C., Camargo, P.B., Cerri, C.E., Durigan, M., Oliveira Júnior, R.C., Vieira, I.C.G., Barlow, J. 2014. A large-scale field assessment of carbon stocks in human-modified tropical forests. Glob. Change Biol. 20 (12), 3713-3726.

Bonan, G.B. 2008. Forests and climate change: forcings, feedbacks, and the climate benefits of forests. Science, 320, 1444-1449.

Brown, S., Lugo, A.E. 1990. Tropical secondary forests. J. Trop. Ecol. 6, 1-31.

Castilho, C.V., Magnusson, W.E. R., de Araújo, N.O., Luizão, R.C.C., Luizão, F.J., Lima, A.P., Higuchi, N. 2006. Variation in aboveground tree live biomass in a central Amazonian Forest: Effects of soil and topography. For. Ecol. Manag. 234, 85-96.

Chambers, J. Q., N. Higuchi, J. P. Schimel, L. V. Ferreira, J. M. Melack. Decomposition and carbon cycling of dead trees in tropical forests in central Amazon. 2000. Oecologia 122(3), 380-388,

Chapin, F.S., Zavaleta, E.S., Eviner, V.T., Naylor, R.S., Vitousek, P.M., Reynolds, H.L., Hooper, D.U., Lavorel, S., Sala, O.E., Hobbie, S.E., Mack, M.C., Díaz, S. 2000. Consequences of changing biodiversity. Nature 405, 234-242.

Chave, J., M. Rejou-Mechain, A. Burquez, et al. Improved allometric models to estimate the aboveground biomass of tropical trees. 2014. Glob. Change Biol. $20(10), 3177-3190$.

Chen, J.Q., Saunders, S.C., Crow, T.R., Naiman, R.J., Brosofske, K.D., Mroz, G.D., Brookshire, B.L., Franklin, J.F., 2006. Microclimate in forest ecosystem and landscape ecology - Variations in local climate can be used to monitor and compare the effects of different management regimes. Bioscience 49, 288-297.

Costa, K.M. 2015. 0 estoque de carbono na vegetação e no solo em fragmentos florestais de paisagens tropicais. São Paulo University, 66 pp. 
d'Albertas, F., Costa, K., Romitelli, I., Barbosa, J.M., Vieira, S.A., Metzger, J.P. 2018. Lack of evidence of edge age and additive edge effects on carbon stocks in a tropical forest. For. Ecol. Manage 407(1), 57-65.

D’Angelo, S., Andrade, A., Laurance, S.G., Laurance, W.F., Mesquita, R., 2004. Inferred causes of tree mortality in fragmented and intact Amazonian forests. J. Trop. Ecol. 20, 243-246.

D’Oliveira, M.V.N., Figueiredo, E.O., Papa, D.A. 2014. Uso do Lidar como ferramenta para o manejo de precisão em florestas tropicais. Brasília, DF : Embrapa, 132 pp.

Espirito-Santo, F.D.B, Keller, M.M., Linder, E., Oliveira Junior, R.C., Pereira, C., Oliveira, C.G. 2014. Gap formation and carbon cycling in the Brazilian Amazon: measurement using high-resolution optical remote sensing and studies in large forest plots. Plant Ecol. Divers. 7, 305-318.

Galindo-Gonzalez, J., Guevara, S., Sosa, V. 2000. Bat- and bird-generated seed rains at isolated trees in pastures in a tropical rainforest. Conserv. Biol. 14, 16931703.

Giam, X. 2017. Global biodiversity loss from tropical deforestation. PNAS, 114 (23), 5775-5777.

Goldberg, E.E. and Ries, L. 2010. edgefx: an R package for edge effects on an ecological landscape. In.

Goodman, R., O. L. Phillips, D. Castillo Torres, L. Freitas, S. T. Cortese, A. Monteagudo, T. R. Baker. 2013. Amazon palm biomass and allometry. For. Ecol. Manage., 310, 994-1004.

Guevara, S., Meave, J., Moreno-Casasola, P., Laborde, J. 1992. Floristic composition and structure of vegetation under isolated trees in Neotropical pastures. J. Veg. Sci. 3, 655-664.

Guevara, S., Laborde, J. 1993. Monitoring seed dispersal at isolated standing trees in tropical pastures - consequences for local species availability. Veget. 108, 319-338.

Guevara, S., Laborde, J., Sanchez-Rios, G. 2004. Rainforest regeneration beneath the canopy of fig trees isolated in pastures of Los Tuxtlas, Mexico. Biotropica $36,99-108$. 
Hoekstra, J.M., Boucher, T.M., Ricketts, T.H., Roberts, C. 2005. Confronting a biome crisis: global disparities of habitat loss and protection. Ecol. Lett. 8, 23-29.

Hunter, M.O., Keller, M., Morton, D., Cook, B., Lefsky, M., Ducey, M., Saleska, S., de Oliveira, R.C., Schietti, J. 2015. Structural Dynamics of Tropical Moist Forest Gaps. PLoS ONE 10(7).

Joly, C.A., Rodrigues, R.R., Metzger, J.P., Haddad, C.F.B., Verdade, L.M., Oliveira, M.C., Bolzani, V.S. 2010. Biodiversity Conservation Research, Training, and Policy in São Paulo. Science 328 1358-1359.

Joly, C.A., Metzger, J.P., Tabarelli, M. 2014. Experiences from the Brazilian Atlantic Forest: ecological findings and conservation initiatives. New Phytol. 204459-73.

Jucker, T., Caspersen, J., Chave, J., Antin, C., Barbier, N. et al. 2017. Allometric equations for integrating remote sensing imagery into forest monitoring programmes. Glob. Change Biol. 23 177-190.

Koricheva, J., Gurevitch, J., Mergensen, K. 2013. Handbook of meta-analysis in ecology and evolution. Princeton University Press, Princeton.

Laurance, W.F., Laurance, S.G., Ferreira, L.V., Rankinde Merona, J.M., Gascon, C., Lovejoy, T.E. 1997. Biomass collapse in Amazonian forest fragments. Science 278, 1117-1118.

Laurance, W.F., Perez-Salicrup, D., Delamonica, P., Fearnside, P.M., D’Angelo, S., Jerozolinski, A., Pohl, L., Lovejoy, T.E. 2001. Rainforest fragmentation and the structure of Amazonian liana communities. Ecology 82, 105-116.

Laurance, W.F., Camargo, J.L.C., Luizão, R.C.C., Laurance, S.G., Pimm, S.L., Bruna, E.M., Stouffer, P.C., Williamson, G.B., Benítez-Malvido, J., Vasconcelos, H.L., Van Houtan, K.S., Zartman, S.E., Boyle, S.A., Didham, R.K., Andrade, A., Lovejoy, T.E. 2011. The fate of Amazonian forest fragments: A 32-year investigation. Biol. Conserv. 144, 56-67.

Lôbo, D., Leão, T., Melo, F. P. L., Santos, A., Tabarelli, M. 2011. Forest fragmentation drives Atlantic forest of northeastern Brazil to biotic homogenization. Diversity and Distributions, 17, 287-296.

Malcolm, J.R., 1994. Edge Effects in Central Amazonian Forest Fragments. Ecology $75,2438-2445$. 
Martinelli, L.A., Almeida, S., Brown, I.F., Moreira, M.Z., Victoria, R.L., Filoso, S., Ferreira, C.A.C., Thomas, W.W. 2000. Variation in Nutrient Distribution and Potential Nutrient Losses by Selective Logging in a Humid Tropical Forest of Rondonia, Brazil. Biotropica 32, 597-613.

McCulloh, K.A., Meinzer, F.C., Sperry, J.S., Lachenbruch, B., Voelker, S.L., Woodruff, D.R., Domec, J.C. 2011. Comparative hydraulic architecture of tropical tree species representing a range of successional stages and wood density. Oecologia 167 (1), 27-37.

Melito, M. O. 2016. Efeitos da fragmentação florestal na biomassa em florestas tropicais. São Paulo University, 126 pp.

Melito, M., Metzger, J.P., de Oliveira, A.A. 2018. Landscape-level effects on aboveground biomass of tropical forests: a conceptual framework. Glob. Change Biol. 24: 597-607.

Metzger, J. P. 2009. Conservation issues in the Brazilian Atlantic forest. Biol. Conserv. 142, 1138-1140.

Michalski, F., Nishi, I., Peres, C. A. 2007. Disturbance-mediated drift in tree functional groups in Amazonian forest fragments. Biotropica,39, 691-701.

Palace, M., M. Keller, G. P. Asner, J. N. M. Silva, C. Passos, 2007: Necromass in undisturbed and logged forests in the Brazilian Amazon. Forest Ecol. Manage. 238, 309-318.

Pan, Y., Birdsey, R.A., Fang, J., Houghton, R., Kauppi, P.E., Kurz, W.A., Phillips, O.L., Shvidenko, A., Lewis, S.L., Canadell, J.G., Ciais, P., Jackson, R.B., Pacala, S.W., McGuire, A.D., Piao, S., Rautiainen, A., Sitch, S., Hayes, D. 2011. A large and persistent carbon sink in the world's forests. Science 333, 988-993.

Poorter, L., Wright, S.J., Paz, H., Ackerly, D.D., Condit, R., Ibarra-Manríquez, G., Harms, K.E., Licona, J.C., Martínez-Ramos, M., Mazer, S.J., Muller-Landau, H.C., Peña-Claros, M., Webb, C.O., Wright, I.J. 2008. Are functional traits good predictors of demographic rates? Evidence from five neotropical forests. Ecology, 89(7), 1908-1920.

Poorter, L., Bongers, F., Aide, T.M., et al. 2016. Biomass resilience of Neotropical secondary forests. Nature 530, 212-225. 
Pullin, A.S., Stewart, G.B. 2006. Guidelines for systematic review in conservation and environmental management. Conserv. Biol., 20, 1647-56.

Pütz, S., Groeneveld, J., Alves, L.F., Metzger, J.P., Huth, A. 2011. Fragmentation drives tropical forest fragments to early successional states: a modeling study for Brazilian Atlantic forests. Ecol. Model. 222, 1986-1997.

R Development Core Team. 2017. R: A language and environment for statistical computing. R Foundation for Statistical Computing, Vienna, Austria. ISBN 3900051-07-0, Available in: URL http://www.R-project.org.

Rezende, C.L., Scarano, F.R., Assadd, E.D., Joly, C.A., Metzger, J.P., Strassburgg, B.B.N., Tabarelli, M., Fonseca, G.A., Mittermeier, R.A. 2018. From hotspot to hopespot: An opportunity for the Brazilian Atlantic Forest. Perspectives in Ecology and Conservation, 16 (4), pp. 208-214.Ribeiro, M.C., Metzger, J.P., Martensen, A.C., Ponzoni, F.J., Hirota, M.M., 2009. The Brazilian Atlantic Forest: How much is left, and how is the remaining forest distributed? Implications for conservation. Biol. Conserv. 142, 1141-1153.

Ries, L., Fletcher, R.J., Battin, J., Sisk, T.D., 2004. Ecological Responses to Habitat Edges: Mechanisms, Models, and Variability Explained. Annu. Rev. Ecol. Evol. Syst. 35, 491-522.

Rodrigues, R.R., Joly, C.A., Brito, M.C.W., Paese, A., Metzger, J.P., Cassati, L., Nalon, M.A., Menezes, N., Ivanauskas, N.M., Bolzani, V., Bononi, V.L.R. 2008. Diretrizes para conservação e restauração da biodiversidade no Estado de São Paulo. Governo do Estado de São Paulo, São Paulo.

Romitelli, I., D'Albertas, F., Costa, K., Vieira, S.A., Metzger, J.P. Tropical forests in human-dominated landscapes present low biomass stocks and high spatial variability, in prep.

Sanderson, E.W., Jaiteh, M., Levy, M.A., Redford, K.H., Wannebo, A.V., Woolmer, G. 2002. The human footprint and the last of the wild. Bioscience 52, 891-904.

Silva, WG.I, Metzger, JP., Simões, S., Simonetti, C. 2007. Terrain influence on the spatial distribution of the Atlantic Forest cover on the Ibiúna Plateau, SP. Braz. J. Biol, 67 (3), 403-411.

Silva, WGS, Metzger, JP, Bernacci, LC, Catharino, ELM, Durigan, G, Simões, S. 2008. Relief influence on tree species richness in secondary forest fragments of Atlantic Forest, SE, Brazil. Acta Botanica Brasilica 22 (2): 589-598 
Soares-Filho, B., Rajão, R., Macedo, M., Carneiro, A., Costa, W., Coe, M., Rodrigues, H., Alencar, A. 2014. Cracking Brazil's Forest Code. Science 344, 363-364.

Tabarelli, M., Aguiar, A.V., Ribeiro, M.C., Metzger, J.P., Peres, C.A. 2010. Prospects for biodiversity conservation in the Atlantic Forest: Lessons from aging humanmodified landscapes. Biol. Conserv. 143, 2328-2340.

Teixeira, A.M.G., Soares-Filho, B.S., Freitas, S.R., Metzger, J.P., 2009. Modeling landscape dynamics in an Atlantic Rainforest region: Implications for conservation. For. Ecol. Manag. 257, 1219-1230.

Vieira, S.A., Alves, L.F., Duarte-Neto, P.J.M, Martins, S.C., Veiga, L.G., Scaranello, M.A., Picollo, M.C., Camargo, P.B., do Carmo, J.B., Neto, E.S., Santos, F.A.M., Joly, C.A., Martinelli, L.A. 2011. Stocks of carbon and nitrogen and partitioning between above- and belowground pools in the Brazilian coastal Atlantic Forest elevation range. Ecol. Evol. 1, 421-434.

Wasser, L., Day, R., Chasmer, L., Taylor, A. 2013. Influence of Vegetation Structure on Lidar-derived Canopy Height and Fractional Cover in Forested Riparian Buffers During Leaf-Off and Leaf-On Conditions. PLoS One 8(1).

West, G.B., Brown, J.H., Enquist, B.J. 1999. A general model for the structure and allometry of plant vascular systems. Nature, 400, 664-667.

Whately, M., Cunha, P. 2006. Um olhar sobre o maior manancial de água da Região Metropolitana de São Paulo. In. Instituto Socioambiental São Paulo.

Zald, H.S.J., Wulder, M.A., White, J.C., Hilker, T., Hermosilla, T., Hobart, G.W., Coops, N.C. 2016. Integrating Landsat pixel composites and change metrics with lidar plots to predictively map forest structure and aboveground biomass in Saskatchewan, Canada. Remote Sens. Environ. 176, 188-201.

Zuur, A.G., Leno, E.N., Walker, N.J., Saveliev, A.A., Smith, G.M. 2009. Mixed effects models and extensions in ecology with R. Springer, New York. 
3 Table 1 - Best supported models to explain variation in the carbon stock.

4 Explanatory variables considered: edge effect, forest cover and slope. Each model

5 is described by $\Delta$ AIC, the degrees of freedom (df) and weight. The tilde $(\sim)$ means

6 the function and the colon (:) the interaction.

7

\begin{tabular}{|c|c|c|c|}
\hline Model & $\Delta \mathrm{AIC}$ & df & weight \\
\hline $\begin{array}{l}\text { carbon } \sim \text { edge effect }+ \text { forest cover }+ \text { slope }+ \text { edge effect }: \text { forest cover }: \\
\text { slope }\end{array}$ & 0 & 6 & 0.8268 \\
\hline carbon $\sim$ edge effect + forest cover + edge effect $:$ forest cover & 3.7 & 5 & 0.1297 \\
\hline carbon $\sim$ edge effect + forest cover + slope & 5.9 & 5 & 0.0424 \\
\hline carbon $\sim$ edge effect + forest cover & 13.3 & 4 & 0.0011 \\
\hline carbon $\sim$ forest cover + slope + forest cover $:$ slope & 285.7 & 5 & $<0.001$ \\
\hline carbon $\sim$ forest cover + slope & 299 & 4 & $<0.001$ \\
\hline carbon $\sim$ forest cover & 318.5 & 3 & $<0.001$ \\
\hline carbon $\sim$ edge effect + slope & 664.2 & 4 & $<0.001$ \\
\hline carbon $\sim$ edge effect + slope + edge effect $:$ slope & 664.9 & 5 & $<0.001$ \\
\hline carbon $\sim$ edge effect & 675.2 & 3 & $<0.001$ \\
\hline carbon $\sim$ slope & 1038.5 & 3 & $<0.001$ \\
\hline null & 31352.6 & 1 & $<0.001$ \\
\hline
\end{tabular}




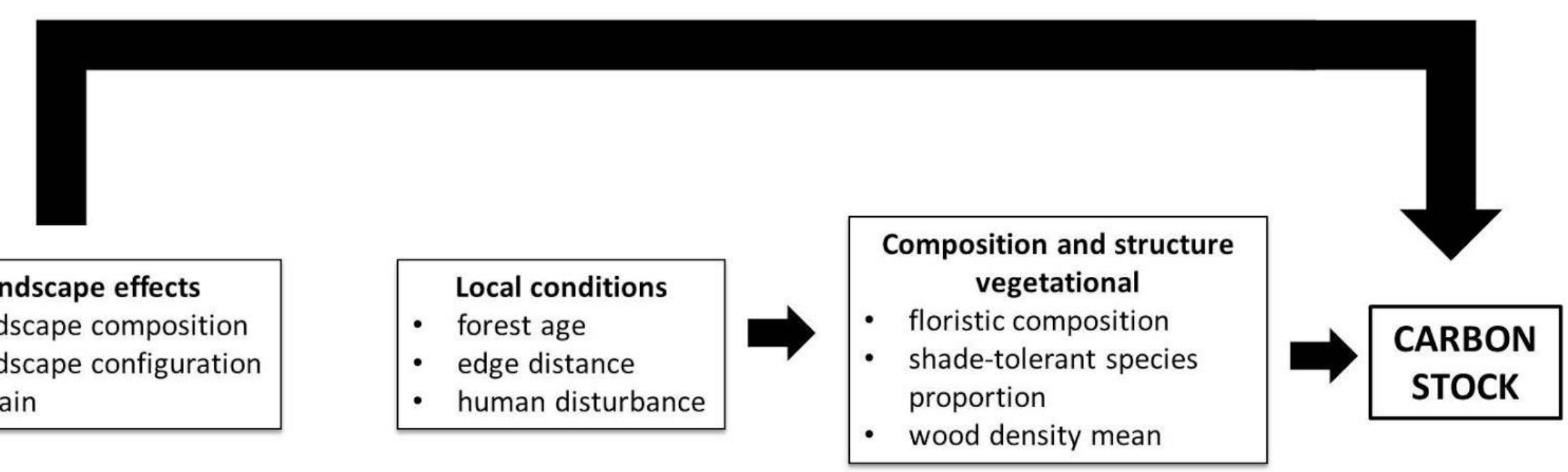

3 Figure 1. . Illustrative scheme of the landscape and plot-level explaining carbon

4 stock spatial distribution. 


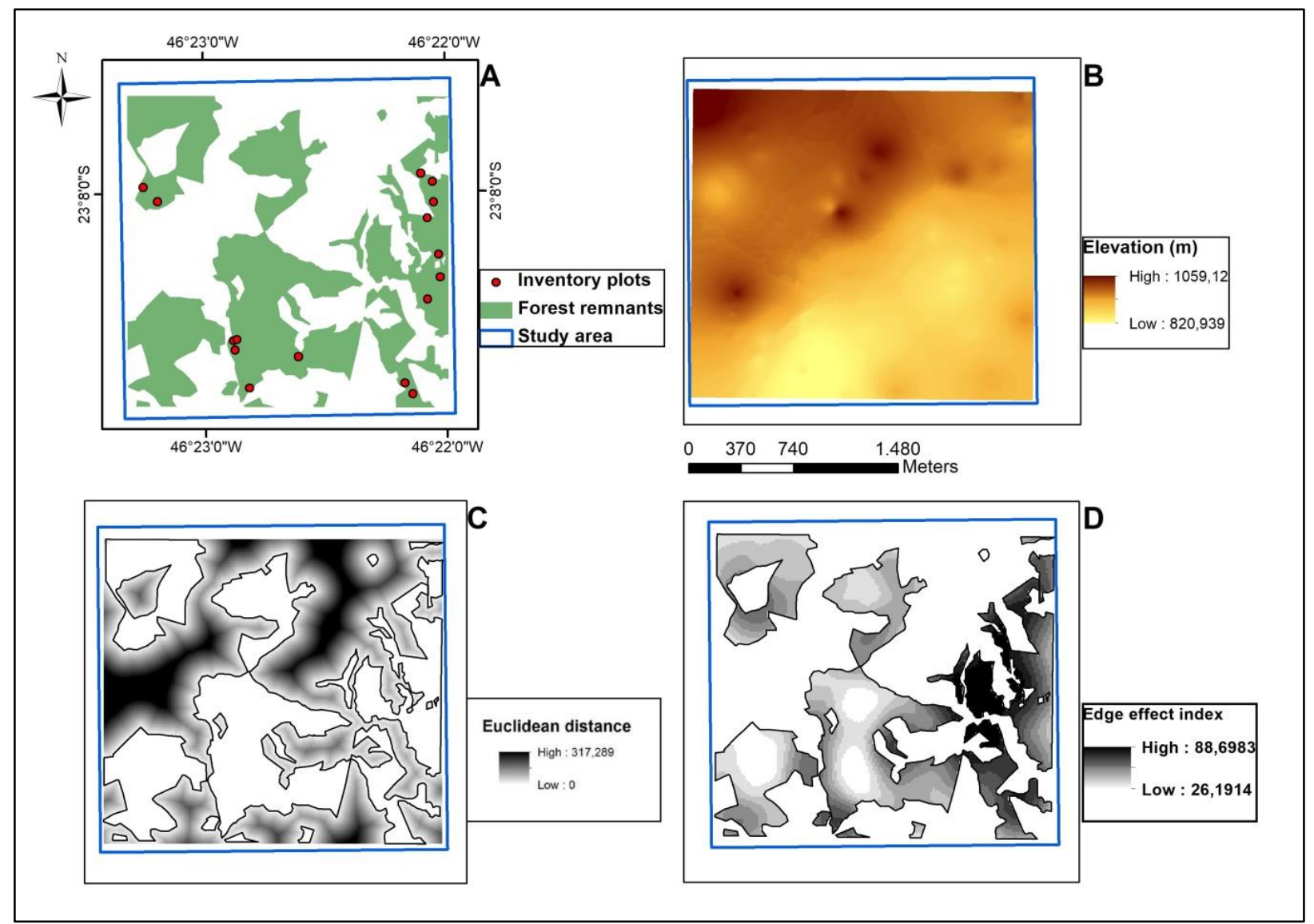

1

2 Figure 2. Study area in Southeastern Brazil showing (A) the forest cover

3 (43.11\%) and the 16 inventory plots (red points); (B) the elevation; (C) the

4 Euclidean distance of any forest area to an edge; and (D) the edge effect index. All

5 maps from $A$ to $D$ are under the same spatial scale. 


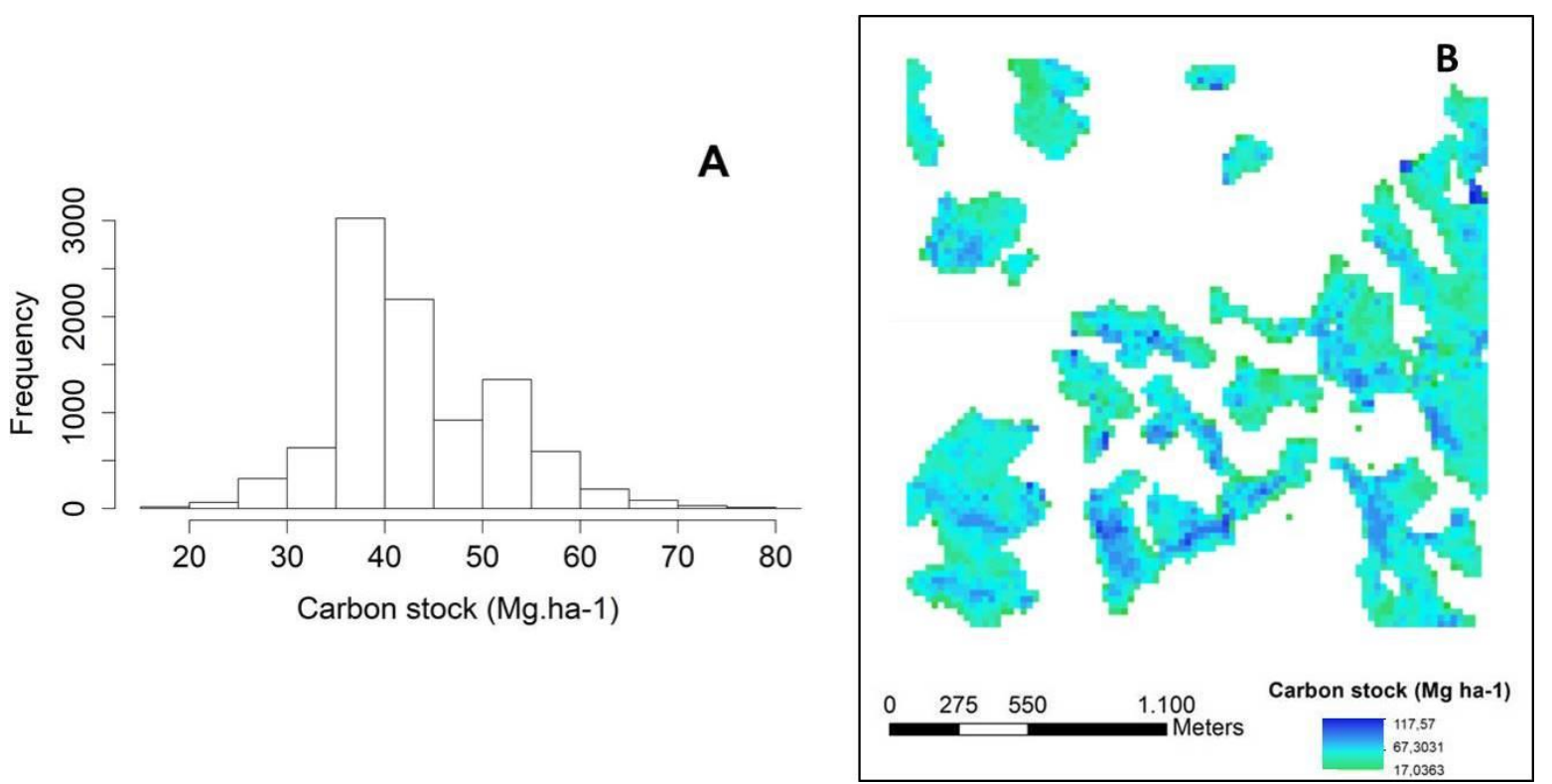

3 Figure 3. Carbon stock data of the 215 ha of native vegetation observed in the

4 Cantareira-Mantiqueira corridor. A) Histogram of carbon stock extrapolation for

5 the whole area, with red points representing data from forest inventory (16

6 plots); B) Forest carbon stock map 


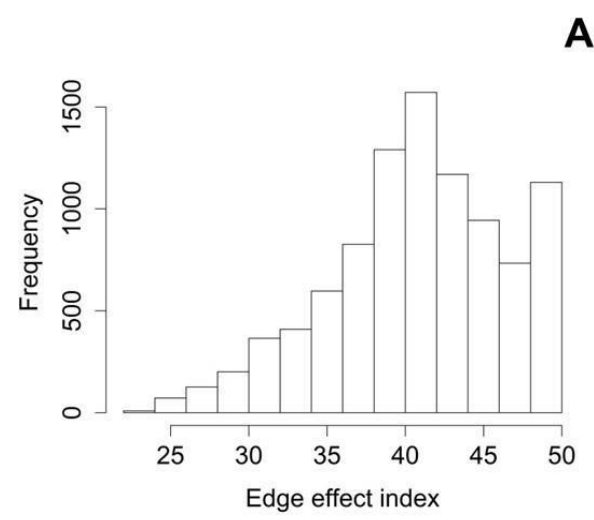

A

D

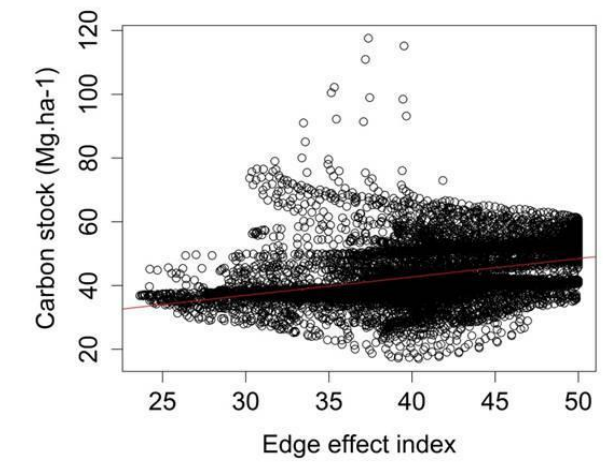

B
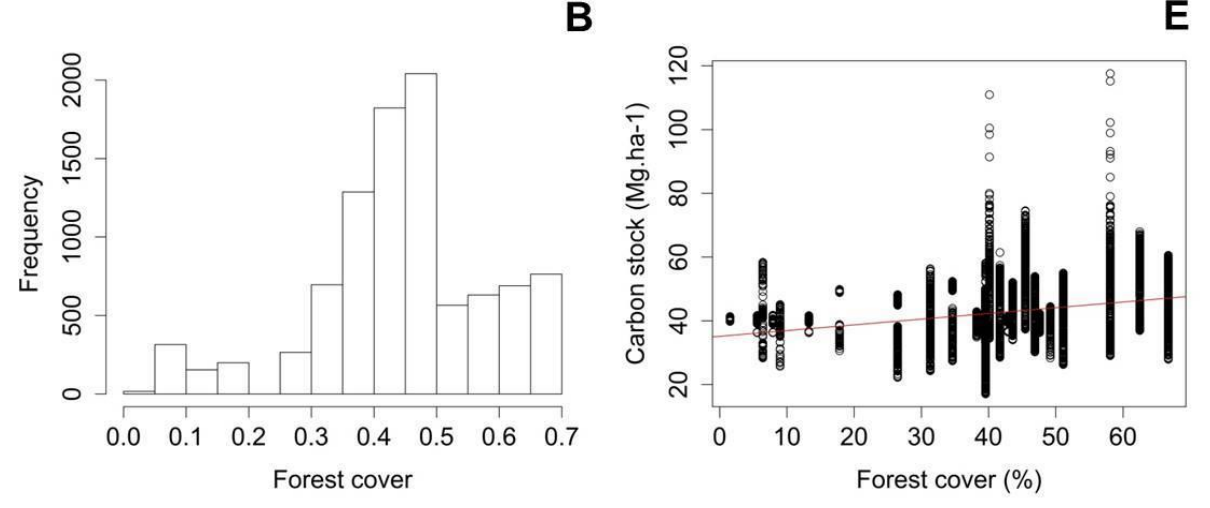

C
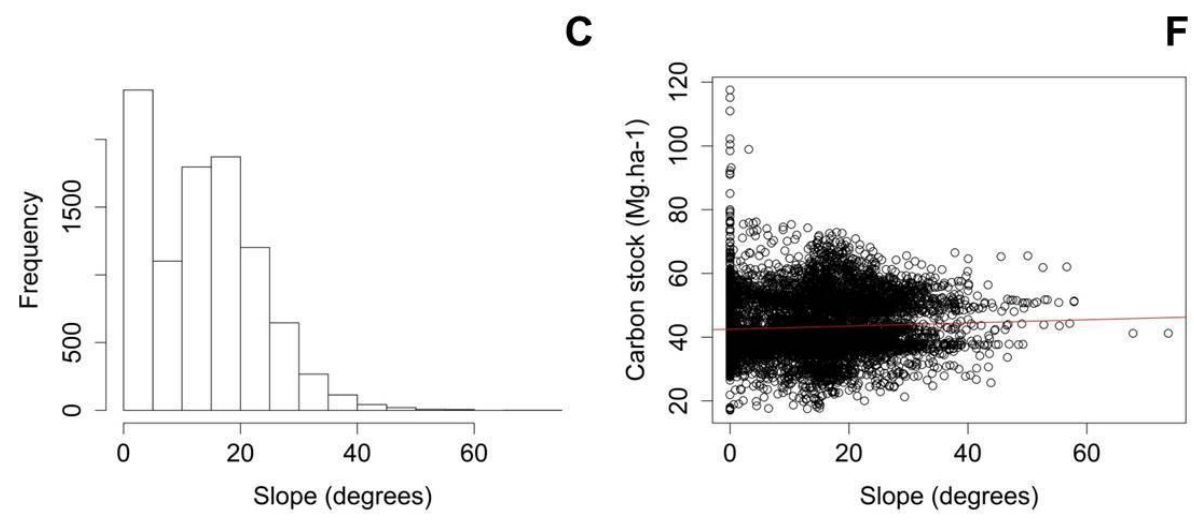

3 Figure 4. Histogram of explanatory variables: A) edge effect index; B) forest cover

4 and; C) slope. Relationships of Carbon stock with the three selected explanatory

5 variables: $D)$ edge effect index $\left(R^{2}=0.368\right)$; $)$ forest cover $\left(R^{2}=0.276\right)$; and; $\left.F\right)$

6 slope $\left(\mathrm{R}^{2}=0.055\right)$. The red line represents tendencies of those relations. 


\section{carbon stock}

0.85

1.00

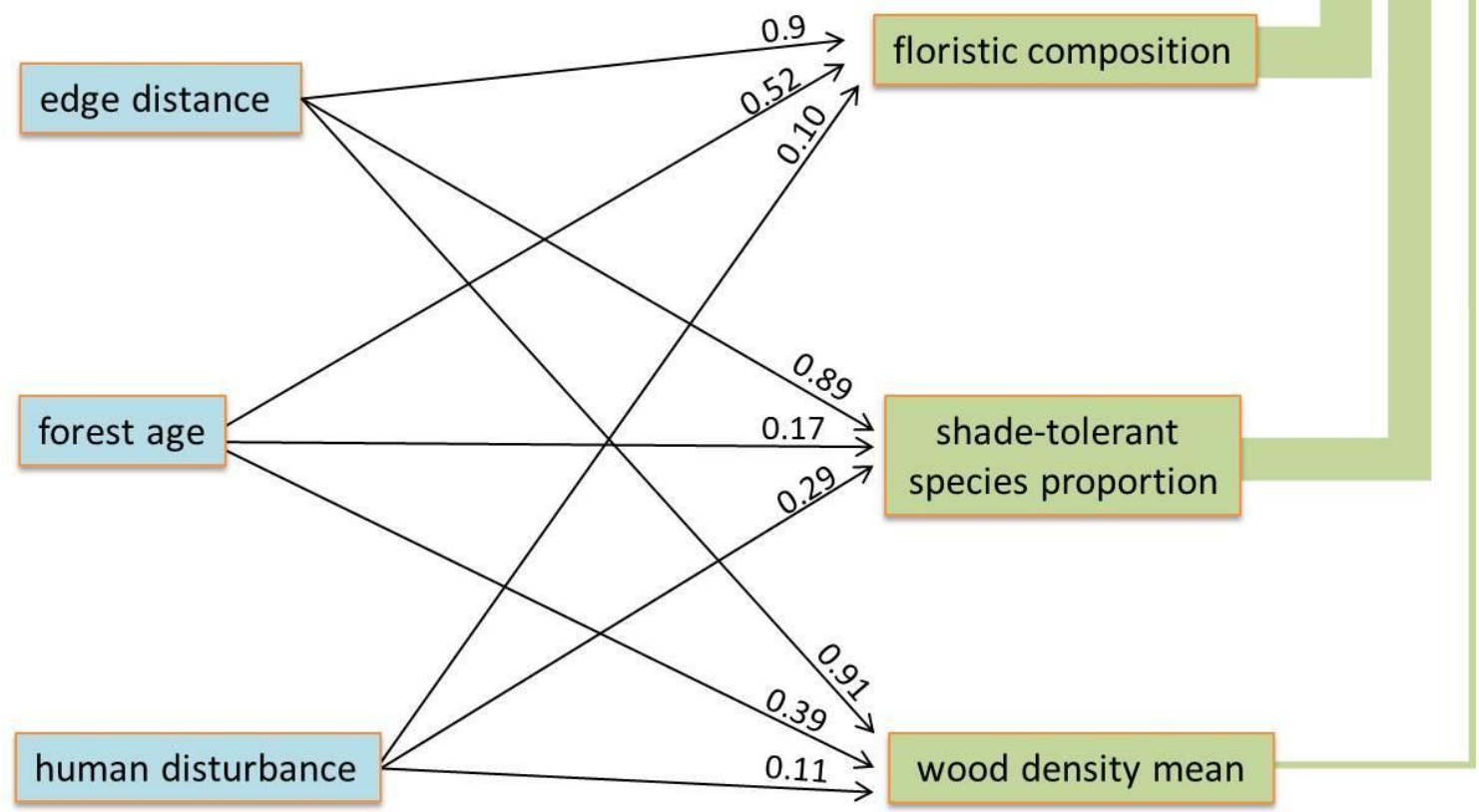

2 Figure 5. Illustrative scheme of the plot-level model explaining carbon stock

3 spatial distribution. Green arrows correspond to composition and structure

4 vegetational affecting carbon stock, in these the thickness of the arrows initiates

5 the magnitude of the explanatory power of the variables. The black arrows

6 correspond tolocal conditions affecting composition and structure vegetational.

7 The explanatory variable weight (The explanation power of each variable by AICc

8 model selection is presented for all arrows. 
1 Table S1 - List of species observed in the 16 studied plots from the Cantareira-

2 Mantiqueira corridor and their corresponding wood density and family.

\begin{tabular}{lcc}
\hline Specie & Wood density (g.cm-3) & Family \\
\hline Schinus terebinthifolia & 0.62 & Anacardiaceae \\
Tapirira guianensis & 0.493 & Anacardiaceae \\
Annona cacans & 0.55 & Annonaceae \\
Annona sylvatica & 0.55 & Annonaceae \\
Guatteria australis & 0.55 & Annonaceae \\
Aspidosperma australis & 0.83 & Apocynaceae \\
Aspidosperma camporum & 0.83 & Apocynaceae \\
Aspidosperma olivaceum & 0.83 & Apocynaceae \\
Aspidosperma parviflorum & 0.743 & Apocynaceae \\
Aspidosperma ramiflorum & 0.71 & Apocynaceae \\
Tabernaemontana laeta & 0.49 & Apocynaceae \\
Schefflera calva & 0.436 & Araliaceae \\
Vernonanthura divaricata & 0.54 & Asteraceae \\
Handroanthus sp. & 0.4 & Bignoniaceae \\
Cordia sellowiana & 0.49 & Boraginaceae \\
Protium heptaphyllum & 0.55 & Burseraceae \\
Celtis iguanaea & 0.77 & Cannabaceae \\
Trema micrantha & 0.245 & Cannabaceae \\
Maytenus evonymoides & 0.4 & Celastraceae \\
Maytenus salicifolia & 0.4 & Celastraceae \\
Hirtella hebeclada & 0.72 & Chrysobalanaceae \\
Clethra scabra & 0.53 & Clethraceae \\
Tovomitopsis paniculata & 0.4 & Clusiaceae \\
Terminalia sp. & 0.58 & Combretaceae \\
Lamanonia ternata & 0.62 & Cunoniaceae \\
Diospyros inconstans & 0.83 & Ebenaceae \\
Sloanea guianensis & 0.861 & Erythroxylaceae \\
Erythroxylum deciduum & 0.81 & Euphorbiaceae \\
Actinostemon concepcionis & 0.907 & Euphorbiaceae \\
Actinostemon concolor & 0.907 & Euphorbiaceae \\
Alchornea glandulosa & 0.4 & \\
Croton floribundus & 0.6 & \\
Sapium glandulosum & 0.27 & \\
\hline & & \\
& &
\end{tabular}


1 Table S1 - List of species observed in the 16 studied plots from the Cantareira-

2 Mantiqueira corridor and their corresponding wood density and family (cont.).

Specie

Sebastiania brasiliensis

Copaifera langsdorffii

Hymenaea courbaril

Senna macrantera

Senna multijuga

Tachigali cf. denudata

Schenella cf. macrostachya

Andira fraxinifolia

Dalbergia brasiliensis

Lonchocarpus cultratus

Machaerium aculeatum

Machaerium brasiliense

Machaerium hatschbachii

Machaerium nyctitans

Machaerium stipitatum

Machaerium villosum

Abarema jupunba

Anadenanthera colubrina

Balizia pedicellaris

Inga striata

Inga uruguensis

Leucochloron incuriale

Piptadenia gonoacantha
Wood density (g.cm-3)

0.72

0.7

0.71

0.6

0.58

0.52

0.4

0.92

0.91

0.76

0.54

0.66

0.6

0.6

0.6

0.69

0.5

0.86

0.465

0.57

0.58

0.4

0.75
Family

Euphorbiaceae Fabaceae-caesalpinoideae Fabaceae-caesalpinoideae Fabaceae-caesalpinoideae Fabaceae-caesalpinoideae Fabaceae-caesalpinoideae Fabaceae-cerciideae Fabaceae-faboideae

Fabaceae-faboideae

Fabaceae-faboideae

Fabaceae-faboideae

Fabaceae-faboideae

Fabaceae-faboideae

Fabaceae-faboideae

Fabaceae-faboideae

Fabaceae-faboideae

Fabaceae-mimosoideae

Fabaceae-mimosoideae

Fabaceae-mimosoideae

Fabaceae-mimosoideae

Fabaceae-mimosoideae

Fabaceae-mimosoideae

Fabaceae-mimosoideae 
1 Table S1 - List of species observed in the 16 studied plots from the Cantareira-

2 Mantiqueira corridor and their corresponding wood density and family (cont.).

\begin{tabular}{lcc}
\hline Specie & Wood density (g.cm-3) & Family \\
\hline Piptadenia paniculata & 0.75 & Fabaceae-mimosoideae \\
Aegiphila integrifolia & 0.806 & Lamiaceae \\
Vitex polygama & 0.4 & Lamiaceae \\
Cinnamomum triplinerve & 0.41 & Lauraceae \\
Cryptocarya aschersoniana & 0.57 & Lauraceae \\
Endlicheria paniculata & 0.58 & Lauraceae \\
Nectandra grandiflora & 0.61 & Lauraceae \\
Nectandra oppositifolia & 0.51 & Lauraceae \\
Ocotea elegans & 0.62 & Lauraceae \\
Ocotea glaziovii & 0.53 & Lauraceae \\
Ocotea lanata & 0.57 & Lauraceae \\
Ocotea pulchella & 0.65 & Lauraceae \\
Persea willdenovii & 0.4 & Lauraceae \\
Cariniana estrellensis & 0.57 & Lecythidaceae \\
Ceiba speciosa & 0.224 & Malvaceae \\
Eriotheca candolleana & 0.43 & Malvaceae \\
Luehea divaricata & 0.64 & Malvaceae \\
Pseudobombax grandiflorum & 0.39 & Malvaceae \\
Miconia cinnamomifolia & 0.73 & Melastomataceae \\
Miconia petropolitana & 0.68 & \\
\hline & & \\
& &
\end{tabular}

3 
1 Table S1 - List of species observed in the 16 studied plots from the Cantareira-

2 Mantiqueira corridor and their corresponding wood density and family (cont.).

\begin{tabular}{lcc}
\hline Specie & Wood density (g.cm-3) & Family \\
\hline Miconia rigidiuscula & 0.63 & Melastomataceae \\
Cabralea canjerana & 0.41 & Meliaceae \\
Cedrela fissilis & 0.42 & Meliaceae \\
Trichilia pallida & 0.74 & Meliaceae \\
Mollinedia elegans & & \\
Mollinedia schottiana & 0.52 & Monimiaceae \\
Ficus enormis & 0.52 & Monimiaceae \\
Ficus insipida & 0.5 & Moraceae \\
Maclura tinctoria & 0.5 & Moraceae \\
Morus nigra & 0.7 & Moraceae \\
Sorocea bonplandii & 0.517 & Moraceae \\
Calyptranthes grandifolia & 0.67 & Moraceae \\
Campomanesia guazumifolia & 0.78 & Myrtaceae \\
Campomanesia xanthocarpa & 0.45 & Myrtaceae \\
Eugenia aff. florida & 0.45 & Myrtaceae \\
Eugenia cf. florida & 0.722 & Myrtaceae \\
Eugenia cf. uniflora & 0.722 & Myrtaceae \\
Myrceugenia sp. & 0.722 & Myrtaceae \\
Myrcia hebepetala & 0.74 & Myrtaceae \\
Myrcia splendens & 0.74 & Myrtaceae \\
Myrciaria ciliolata & 0.8 & Myrtaceae \\
Psidium guineense & 0.77 & Myrtaceae \\
Guapira opposita & 0.77 & Myrtaceae \\
Pisonia ambigua & 0.83 & Primulaceacea \\
Pera glabrata & 0.4 & Primulaceae \\
Bredemeyera floribunda & 0.65 & Proteaceae \\
Myrsine coriacea & 0.6 & \\
Myrsine gardneriana & 0.64 & Nyctaginaceae \\
Myrsine umbellata & 0.64 & \\
Roupala montana var. brasiliensis & 0.86 & \\
\hline & 0.77 & \\
& & \\
& & \\
& &
\end{tabular}


1 Table S1 - List of species observed in the 16 studied plots from the Cantareira-

2 Mantiqueira corridor and their corresponding wood density and family (cont.).

\begin{tabular}{lcc}
\hline Specie & Wood density (g.cm- & Family \\
\hline Colubrina glandulosa & $\mathbf{3}$ ) & Rhamnaceae \\
Psychotria cf. sessilis & 0.646 & Rubiaceae \\
Psychotria vellosiana & 0.5 & Rubiaceae \\
Rudgea gardenioides & 0.5 & Rubiaceae \\
Zanthoxylum rhoifolium & 0.57 & Rutaceae \\
Casearia decandra & 0.797 & Salicaceae \\
Casearia lasiophylla & 0.563 & Salicaceae \\
Casearia obliqua & 0.681 & Salicaceae \\
Casearia sylvestris & 0.681 & Salicaceae \\
Allophylus edulis & 0.8 & Sapindaceae \\
Cupania vernalis & 0.593 & Sapindaceae \\
Matayba cf. cristae & 0.65 & Sapindaceae \\
Matayba elaeagnoides & 0.8 & Sapindaceae \\
Matayba intermedia & 0.78 & Sapindaceae \\
Cestrum sp. & 0.8 & Solanaceae \\
Solanum cf. erianthum & 0.41 & Solanaceae \\
Solanum cf. variabilis & 0.41 & Solanaceae \\
Solanum mauritianum & 0.41 & Solanaceae \\
Solanum pseudoquina & 0.41 & Solanaceae \\
Boehmeria caudata & 0.41 & Urticaceae \\
Cecropia glaziovii & 0.364 & Urticaceae \\
Cecropia hololeuca & 0.41 & Urticaceae \\
Cecropia pachystachya & 0.43 & Urticaceae \\
Aloysia virgata & 0.41 & Verbenaceae \\
\hline
\end{tabular}

3 Table S2 - Spatial correlation test results (Mantel test) between samples (9444

4 pixels)

\begin{tabular}{cc}
\hline $\begin{array}{c}\text { Pixel size } \\
\text { (m) }\end{array}$ & $\begin{array}{c}\boldsymbol{r} \\
\text { value }\end{array}$ \\
\hline 5 & 0.983 \\
10 & 0.825 \\
15 & 0.634 \\
20 & 0.612 \\
25 & 0.578 \\
\hline
\end{tabular}


1 Table S3 - Best supported models to explain variation in the carbon stock,

2 floristic composition, shade-tolerant species proportion and wood density mean.

3 Each model is described by $\triangle \mathrm{AIC}$, the degrees of freedom ( $\mathrm{df}$ ) and weight. The

4 tilde $(\sim)$ means the function.

\begin{tabular}{|c|c|c|c|}
\hline Model & $\Delta$ AIC & df & weight \\
\hline \multicolumn{4}{|c|}{ Local conditions affecting floristic composition } \\
\hline floristic composition age + edge distance & 0.0 & 4 & 0.440 \\
\hline floristic composition $\sim$ edge distance & 0.2 & 3 & 389 \\
\hline floristic composition age & 3.6 & 3 & 0.071 \\
\hline floristic composition $\sim$ human disturbance + edge dista & 3.8 & 4 & 0.067 \\
\hline composition $\sim$ human $d$ & 6.0 & 3 & 0.022 \\
\hline floris & 7.3 & 4 & 0.011 \\
\hline null & 39.4 & 1 & $<0.001$ \\
\hline \multicolumn{4}{|c|}{ Local conditions affecting shade-tolerant species } \\
\hline $\begin{array}{l}\text { shade-tolerant species proportion } \sim \text { edge dis } \\
\text { shade-tolerant species proportion } \sim \text { human } d\end{array}$ & 0.0 & 3 & 6 \\
\hline edge distance & 2.2 & 4 & 0.182 \\
\hline edge distance & 3.5 & 4 & 98 \\
\hline human disturbance & 3.6 & 3 & 0.093 \\
\hline shade-tolerant species proportion $\sim$ age & 4.5 & 3 & 0.058 \\
\hline shade-tolerant species proportion & & & \\
\hline disturk & 7.4 & 4 & 0.014 \\
\hline null & 26.8 & 1 & $<0.001$ \\
\hline \multicolumn{4}{|l|}{ Local conditions affecting wood density } \\
\hline edge distance & 0.0 & 3 & 0.4880 \\
\hline woo & 0.8 & 4 & 3346 \\
\hline$\sim$ human disturbance + edge distance & 3.4 & 4 & 0.0883 \\
\hline density age & 4.3 & 3 & 0.0562 \\
\hline density $\sim$ human disturbance & 6.0 & 3 & 0.0245 \\
\hline wood density $\sim$ age + human disturbance & 8.1 & 4 & 0.0084 \\
\hline null & 65.7 & 1 & $<0.001$ \\
\hline \multicolumn{4}{|c|}{ Composition and structure vegetational affecting carbon stock } \\
\hline$\sim$ floristic composition + wood density & 0.0 & 4 & 0.843 \\
\hline carbon $\sim$ floristic composition & 3.6 & 3 & 0.136 \\
\hline $\mathrm{n} \sim$ floristic composition + shade-tolerant species & & & \\
\hline proportion & 7.3 & 4 & 0.021 \\
\hline null & 39.4 & 1 & $<0.001$ \\
\hline densi & 246.6 & 3 & $<0.001$ \\
\hline$\sim$ shade-tolerant species proportion + wood density & 248.7 & 4 & $<0.001$ \\
\hline carbon $\sim$ shade-tolerant species proportion & 259.4 & 3 & $<0.001$ \\
\hline
\end{tabular}


1 Table S4 - Human Disturbance Value (HDV) and Human Disturbance Spatial

2 Range (HDSR). The product of those two factors is the human disturbance index.

\begin{tabular}{cc}
\hline \multicolumn{2}{c}{ Human Disturbance Value } \\
Human disturbance type & Human Disturbance Value \\
Selective logging & 5 \\
Livestock trail & 4 \\
Forest gap & 3 \\
Human trail & 2 \\
\hline \multicolumn{2}{c}{ Human Disturbance Spatial Range } \\
\hline Spatial distribution (\%) & Human Disturbance Spatial \\
& Range \\
$10-20$ & 1 \\
$20-40$ & 2 \\
$40-60$ & 3 \\
$60-80$ & 4 \\
$80-100$ & 5 \\
\hline
\end{tabular}




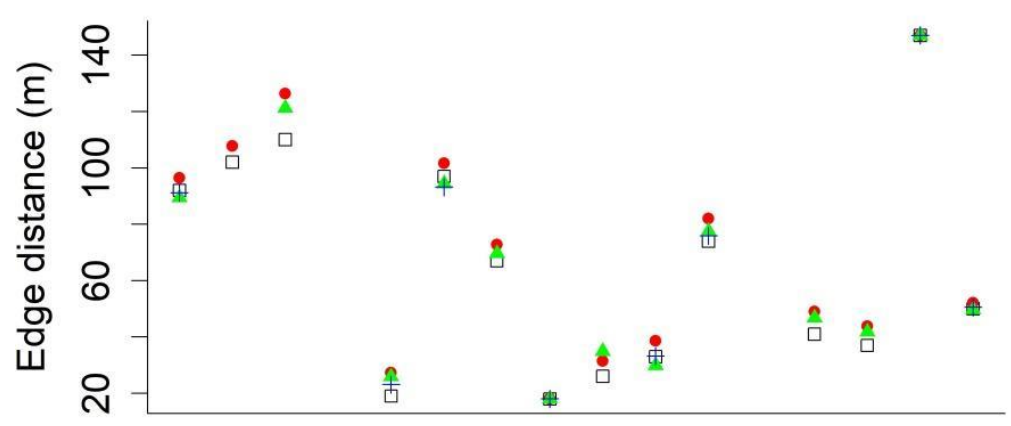

Sampled plots

2

3 Figure S1. Historic edge distance of sampled plots which it is possible observes reduction,

4 increase and constancy of edge distance. Each symbol represents a year: sqaure - 2014; red 5 point -2005 ; green triangle -1985 ; cross -1952 .

6 
A

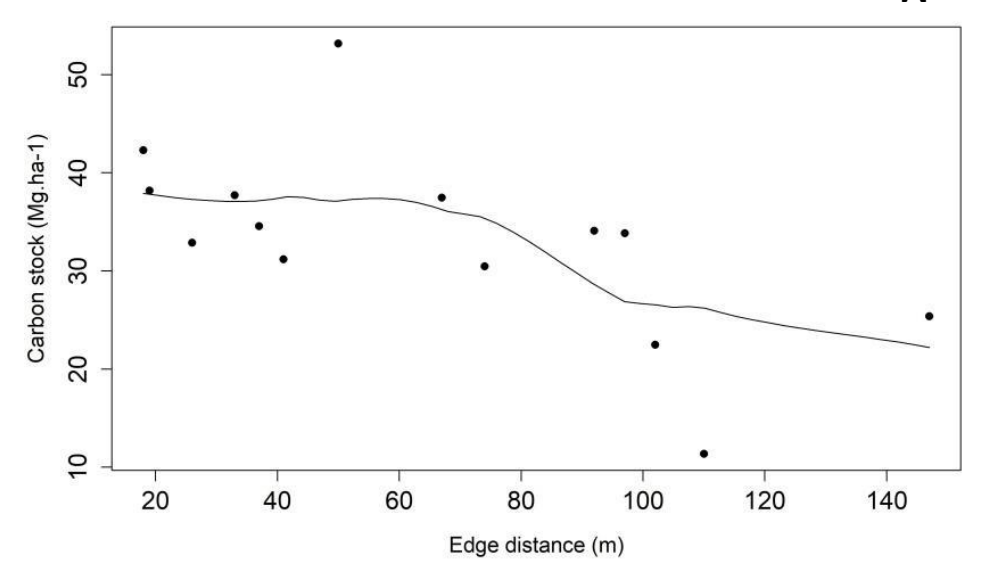

1

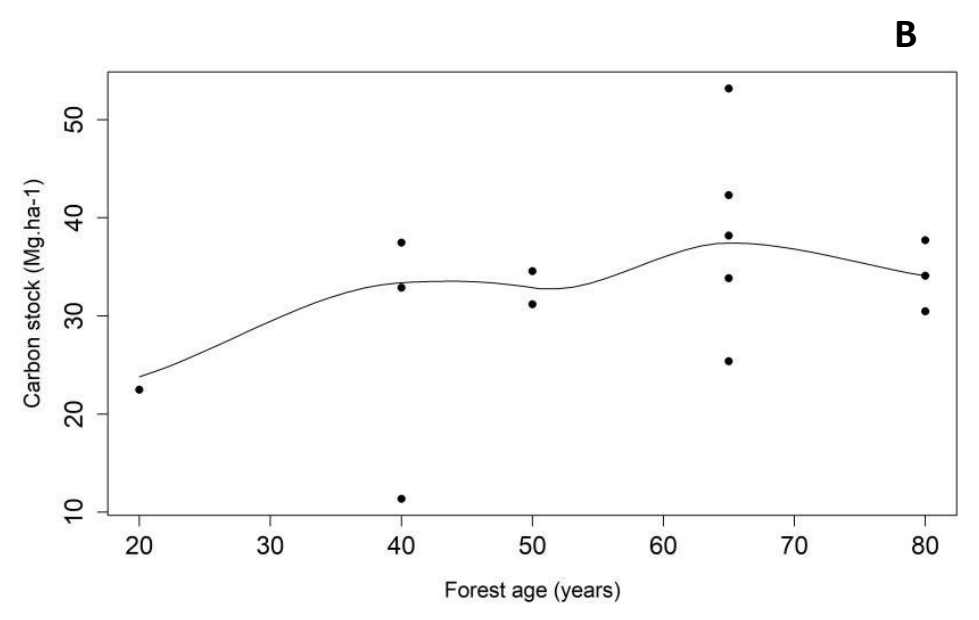

2

3

4 Figure S2. Relation separately between carbon stock and A) edge distance; B) forest age in 5 sampled plots.

6 

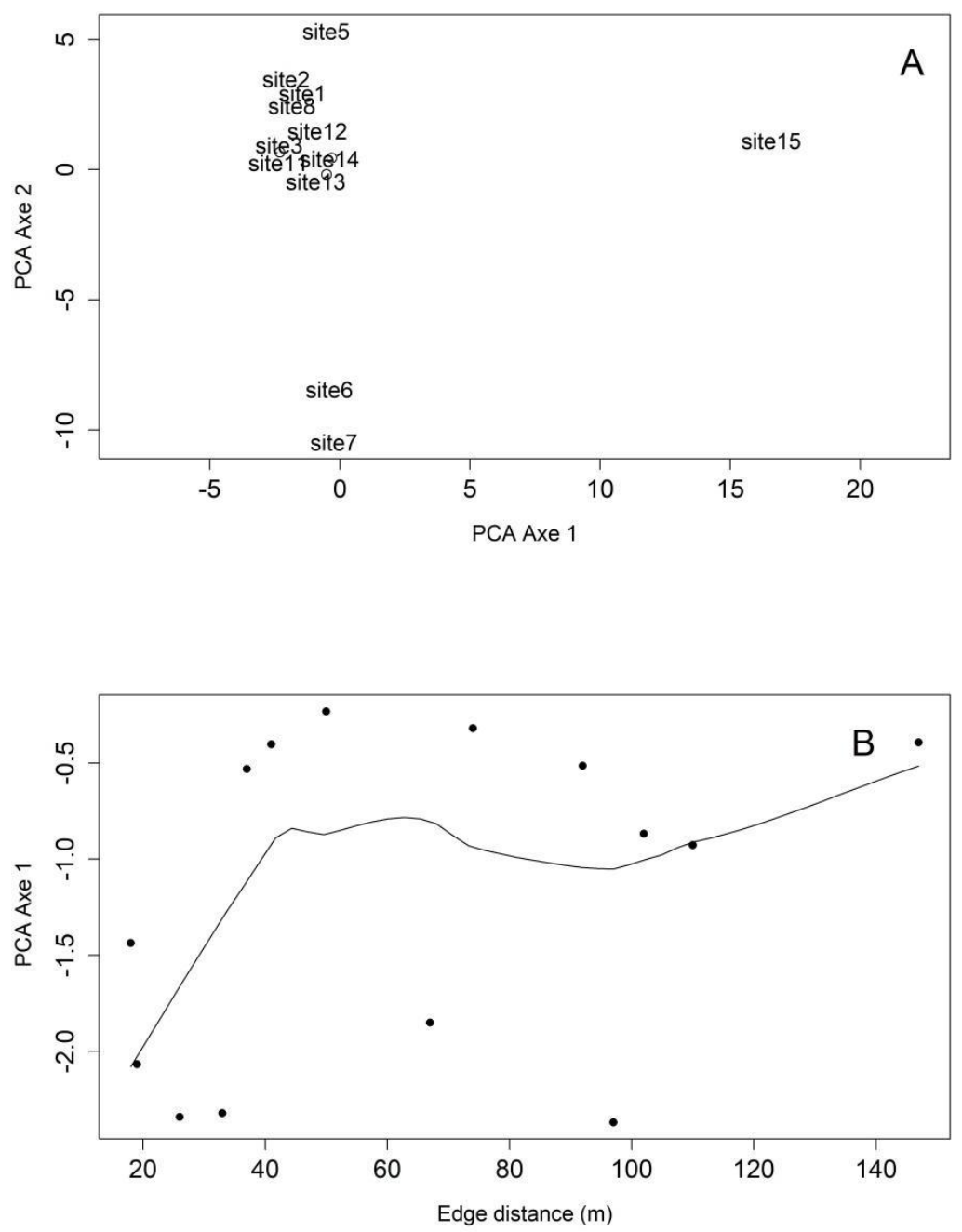

3 Figure S3. Ordination graphs of the PCA based on the sampling of tree community in the

4 sampled plots. A) Ordination with all sampled plots; B) Relation between PCA Axe 1 and 5 edge distance showing the segregation by edge distance (less and more than 40 ).

6 


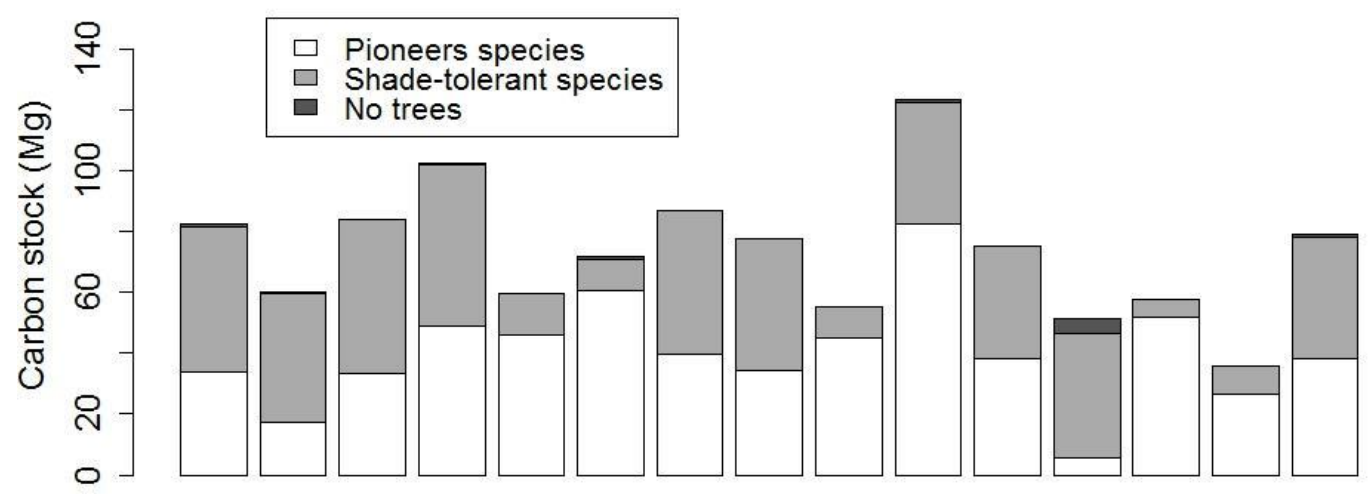

Edge distance

2

3 Figure S4. Contribution of pioneers and shade-tolerant species to carbon stock on sampled

4 plots display according an edge distance gradient,

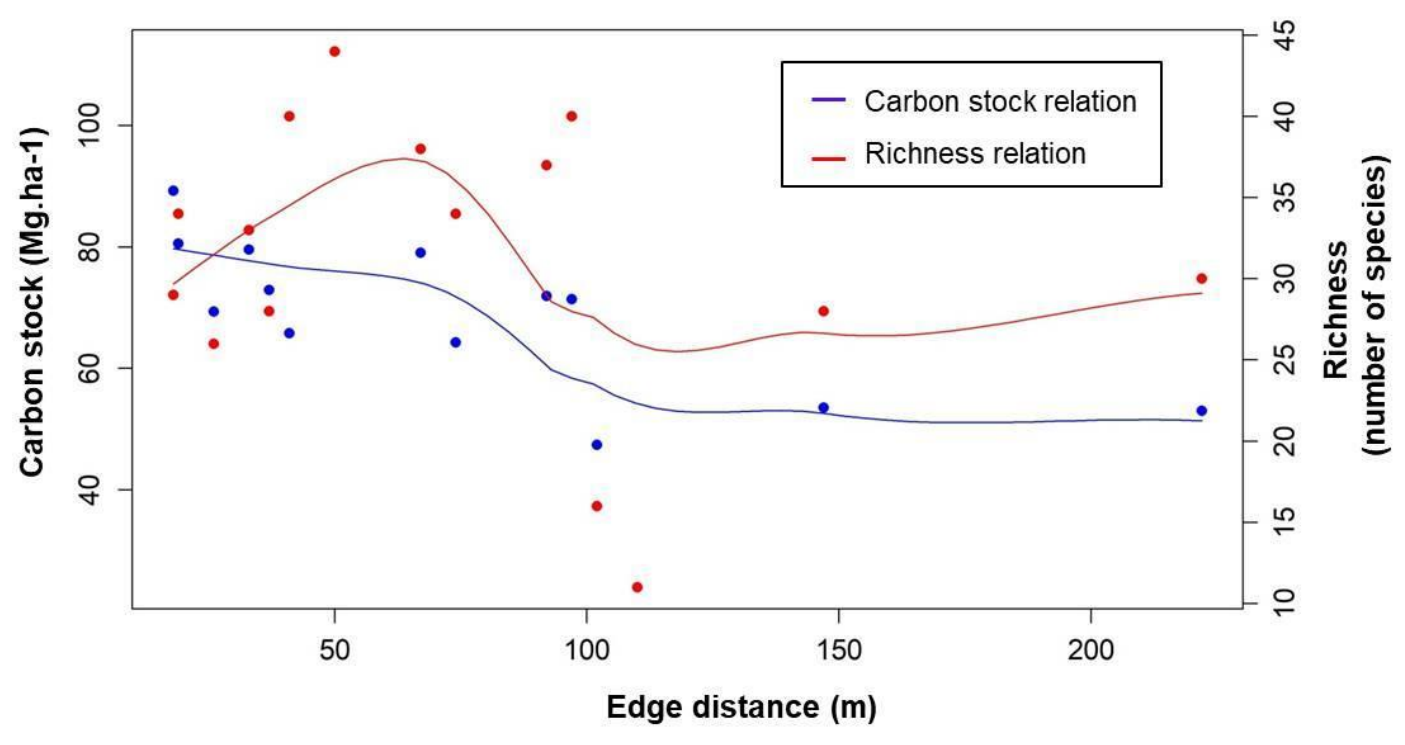

6 Figure S5. Relation between carbon stock and edge distance (blue) and; richness and edge

7 distance (red). 
1 Capítulo 2: “Landscape effects overtake abiotic and age influences on forest

2 biomass in tropical fragmented landscapes"

3 Isabella Romitelli, Jomar Magalhães Barbosa and Jean Paul Metzger

\section{ABSTRACT}

5 The knowledge gap on what processes determine the ability of secondary forests to store carbon is still large. In human-dominated landscapes, landscape-level processes should have an important role. Particularly, landscape composition, habitat fragmentation, connectivity and patch size can affect how forests resist degradation and how they recover. This study aims to evaluate the effects of landscape-level factors on secondary forest biomass in human-dominated landscapes beyond the known role of forest age and terrain variables (elevation, slope, and aspect). In particular, we evaluated how the interaction of forest cover and edge distance affects forest biomass - maximum canopy height $(\mathrm{MCH})$ as a proxy for above-ground biomass - in younger (recent regeneration, about 20-40 years) and older forests ( $>40$ years of regeneration or not clear cut) of human-dominated landscapes of two Brazilian Atlantic forest region, with low and high forest cover. Our results suggest that tree height (and thus above-ground biomass) in human-dominated and fragmented landscapes can be more affected by the landscape composition (forest cover) and structure (edge distance) than by forest age and the topography factors. This pattern occurs in both landscape contexts, i.e. with contrasting forest cover, and for younger and older forests. Our findings may contribute to developing new carbon modeling approaches and carbon conservation initiatives as we pointed out the important role of considering landscape context effects on younger and older forest structure and biomass. 
1 Keywords: Disturbed landscapes, secondary forests, forest structure, Atlantic forest, carbon stock, above-ground biomass, LiDAR

jeopardizing the maintenance of biodiversity (Tabarelli et al., 2012) and the provision of a wide range of ecosystem services (Brown \& Lugo, 1990; Guariguata \& Ostertag, 2001; Naughton-Treves \& Chapman, 2002). Those effects are related to both local and landscape drivers, but our understanding of landscape-level processes is still incomplete. Particularly, considering carbon sequestration process, microclimatic and anthropogenic disturbance drivers on forest structure are well documented at a local level (e.g. Haddad et al., 2015; Reinmann and Hutyra, 2017; Smith et al., 2018) but there are important knowledge gaps of how forest structure and carbon stock are affected by landscape-level processes, related to forest cover (Romitelli et al. submitted), matrix types (Costa, 2015), and edge effects (Laurence et al., 1997; Laurance et al., 2001; Romitelli et al. , in preparation ; Costa, 2015; D’Albertas et al., 2018).

In human-dominated landscapes, secondary forests are characterized by reduced connectivity between forest patches, low matrix permeability, a high extension of areas under edge effects, in addition to the high local risk of extinction, resulting in impoverished communities, with few species and high number of younger and small trees (Melito et al. 2018). As a consequence, we expect multiple interactions between 
1 local and landscape-level factors to determine forest structure, and thus carbon sequestration process and stocks in secondary tropical forests (Romitelli et al., in preparation).

Edge effects at the interface between forest and matrix areas are considered as one of the most important processes acting on forests at the landscape level (Melito et al. 2018). Forest areas located near edges receive more insolation and are usually hotter and drier and are more exposed to wind effects when compared to the forest interior (Laurance et al., 2011). As a consequence, tree species composition is strongly affected by microclimatic changes in forest edges, as well by floristic and functional simplification induced by edge creation (Michalski et al. 2007; Lôbo et al., 2011). In particular, forest edges nearby contrasting or open matrix, such as crops or pasturelands, have higher mortality of large trees (Laurance et al., 1997; D’Angelo et al., 2004) and higher dominance of initial successional species (Laurance et al., 2011). Additionally, highly fragmented landscapes, with large edge extension, will tend to store less carbon than landscapes with the same amount of forest where fragments are bigger and more compact (Pütz et al., 2011). The surrounding forest cover can also affect local biomass. Specifically, we already know that isolated trees in pastures, as well as the amount of forest coverage in the neighboring landscape, may improve local regeneration by attracting seed-dispersing frugivores and facilitating recruitment conditions and seedling establishment (Guevara et al., 1992; Guevara \& Laborde, 1993; GalindoGonzalez et al., 2000; Slocum \& Horvitz, 2000; Slocum, 2001; Guevara \& Laborde, 2004). However, we still need to better understand how the surrounding forest cover determines local level tree height and forest biomass in a fragmented and humandominated landscape context. 
Besides the landscape effects, the accumulation of biomass can also be influenced by local factors. Different abiotic conditions, generally related to geographical topography, soil, and climate, can alter forest regrowth as well as the distribution of big trees (Castilho et al., 2006), and thus can modulate carbon accumulation. The history of human disturbance, which affects the vegetation structure, can also contribute to explain changes in above-ground biomass (Brown \& Lugo, 1990). The interaction of all those factors is also expected. Elevation and slope, for example, may act as a limiting factor for human access as forests located on higher slopes are expected to be less degraded due to the difficulty of human access and consequently those places are more challenging from which to remove trees, leaving more large trees standing and more aboveground biomass (Becknell et al., 2018). This pattern has been observed in the Brazilian Atlantic forest which is characterized by s a rough terrain (Vieira et al., 2011).

Elevation and slope are the most commonly considered topographic variables to forest structure (Salinas-Melgoza et al., 2018). Besides their interaction with human access, those factors are related to air temperature and solar radiation, which affect forest biomass through evapotranspiration rates (Homeier et al. 2010, Sundqvist et al. 2013). The effect of the aspect on forest structure has been well recognized, but in tropical areas, this does not usually play a key role in structuring vegetation (GallardoCruz et al. 2009; Salinas-Melgoza et al. 2018). Solar radiation, that is, the amount of radiant energy received at a certain location varies not only with the amount of sunshine but with slopes, aspect, and adjacent topography (Wilson and Gallant 2000). However, terrain factors may not always be the most important drivers of forest structure because in these fragmented and human-dominated landscapes all the above variables are interacting and the influence of these abiotic factors can be potentially masked due to a 
1 stronger effect of factors directly related to human activities, particularly near forest

2 edges (Berenguer et al., 2014; Romitelli et al., submitted). Besides, in the tropics, the

3 depth of penetration of most microenvironmental conditions (e.g. solar radiation, wind)

4 at newly created edges can be two to five times higher than on older and more densely

5 vegetated edges (Didham and Lawton 1999), which could possibly lead to differences

6 between younger (regenerating) and older forests.

In this context, this study aims to evaluate the effects of landscape-level processes on secondary forest structure in human-dominated landscapes beyond the known role of forest age and terrain variables. We used LiDAR data obtained from two fragmented landscapes of the Brazilian Atlantic forest to answer the following questions: (1) Do landscape-level processes related to forest cover and edge effects affect local forest biomass? (2) What is the relative importance of landscape-level factors to explain variation on forest biomass? (3) Are there differences in how landscape-level factors affect forest biomass between older forests ( $>29$ years) and younger forests (between 4 and 28 years)?

\section{Methods}

\subsection{Study regions}

We obtained data from two regions (Cantareira and Conduru), both located in the Brazilian Atlantic forest (Figure 1A), a highly diverse and endangered tropical forest that experienced unprecedented levels of habitat loss and other human disturbances since the 16th century (Joly et al., 2014). The remaining forest cover ( $28 \%$ of its original distribution; Rezende et al., 2018) consist of small fragments, with $<50$ ha (Ribeiro et al., 2009), including $46 \%$ of this forest at less than $100 \mathrm{~m}$ distant from an edge (Figure 1A; 
1 Ribeiro et al., 2009). The two studied regions present contrasting landscape conditions

2 (Conduru is more forest and less disturbed, while Cantareira is more intensively

3 disturbed and present a lower forest cover), allowing us to explore the effect of distinct

4 regional contexts on processes that modulate forest biomass.

The Cantareira study region $\left(23^{\circ} 01^{\prime} \mathrm{S}\right.$ and $46^{\circ} 15^{\prime} \mathrm{W}^{\prime}$; Figure $\left.1 \mathrm{D}-\mathrm{E}\right)$ is located in Southeast Brazil. It includes an important ecological corridor that was considered of high priority for biodiversity conservation at the state level (Rodrigues et al., 2008; Joly et al., 2010). This region is also characterized by rolling and steep convex hill with elevation ranging between 700 to $1700 \mathrm{~m}$ of altitude. Climate is humid subtropical, with dry winters and hot and humid summers. Annual rainfall varies between 1350 and 2000 $\mathrm{mm}$, and the mean annual temperature ranges between 15 and $22{ }^{\circ} \mathrm{C}$

(www.cpa.unicamp.br). Landscapes of the Cantareira-Mantiqueira corridor are very heterogeneous, comprising different land uses, mostly pasture areas in small properties and reforestation, especially with Eucalyptus spp. Native Atlantic Forest vegetation is classified as a lower montane ombrophilous dense forest (moist forest; IBGE, 2012), in different successional stages and submitted to different levels of disturbance, representing $21 \%$ of the studied region (Whately and Cunha 2006). All the forest areas studied comprising private properties (around 20 small properties) which the mainland uses are pasture and Eucalyptus silviculture. Although the Atlantic Forest Law (http://www.planalto.gov.br/ccivil 03/Ato2004-2006/2006/Lei/L11428.htm) prohibits deforestation in secondary Atlantic forests of intermediate and advanced stages of succession, the human perturbation is quite intense and dynamic which could compromise the ecological succession (Romitelli et al., submitted) The Conduru study region is a protected area (Serra do Conduru State Park) in Southern Bahia, Brazil 
$1 \quad\left(14^{\circ} 23^{\prime} \mathrm{S}\right.$ and $39^{\circ} 04^{\prime} \mathrm{W}$; Figure $\left.1 \mathrm{~B}\right)$. The study sites are located at an elevation of $120-$

$300 \mathrm{~m}$. The average monthly temperature is $24^{\circ} \mathrm{C}$, with an annual average precipitation of 2,000 mm evenly distributed throughout the year (Landau, 2003). The natural vegetation is classified as tropical moist forest (Gouvêa et al., 1976), with the overall topography being undulating to rolling (10-30\% slope)

The Conduru area bounds one of the largest contiguous areas of Atlantic forest in the northeast of Brazil (almost 10,000 ha) and includes patches of secondary forest at different stages of regeneration, active forest restoration sites, and areas of older forest that have been selectively logged in the past, totaling around $80 \%$ of native vegetation. Selective logging, hunting, and fiber harvesting are common throughout the Conduru. Some small patches within the park remain occupied or used for grazing. Several frequently used roads bisect the protected area, and there are trails used by local inhabitants throughout the area (Becknell et al., 2018).

\subsection{LiDAR data and maximum canopy height variable calculation}

The LiDAR data of the Cantareira study region was acquired in October 2014 by an airplane flight with an Optech Orion M300 sensor at an altitude of 853 meters, with a field of view of $10^{\circ}$. Laser-spot spacing was maintained at approximately 86 laser shots m-2. The LiDAR dataset covers two areas of 499 hectares each (35 km distant apart), which includes approximately $43 \%$ of native forest vegetation. In the Conduru region, the LiDAR data was acquired in December 2015 by an airplane flight with an Optech

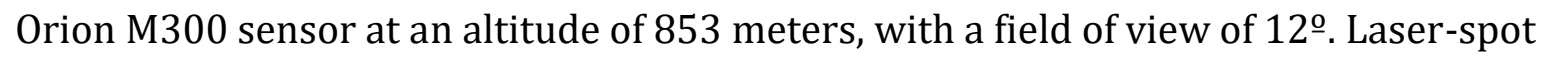
spacing was maintained at approximately 94 laser shots m-2. This LiDAR dataset covers 
1 three areas totaling 4,529 hectares, which includes approximately $82 \%$ of native forest vegetation.

Using the above-mentioned LiDAR data, we calculated the maximum canopy height (MCH). The MCH is a good proxy of above-ground biomass in Atlantic Forest (Becknell et al., 2018). Besides, the MCH variable has been used to study forest structure and tree growth (Wasser et al., 2013). For both study regions, digital terrain models (DTM) were generated from the LiDAR data using a methodological process previously described in Leitold et al. (2015). Then, we calculated a 1-m-pixel-scale MCH model using the 95th percentile threshold of the LiDAR data points (P95 tree height map). To calculate the P95, we used the "Cloudmetrics" utility in FUSION software package, beta version derived from version 3.00 (http://forsys.cfr.washington.edu/fusion.html). We used a 1-m-pixel mean moving window smoothing function to remove anomalies.

\subsection{Landscape factors (forest cover and edge distance)}

To estimate forest cover we used a cartographic data-based supervised classification and vectoring of RapidEye images (5 m). This mapping was carried out within the scope of the High-Resolution Mapping Project of the Brazilian Biomes, executed by the Brazilian Foundation for Sustainable Development (http://mapbiomas.org/pages/database/mapbiomas_collection_download/).

We realized a moving window approach to evaluate how the surrounding amount of forest cover affects forest maximum height, biomass at the pixel level (25 $\mathrm{m}$ ) in three landscape extents (buffer areas of $400 \mathrm{~m}, 800 \mathrm{~m}$, and $1000 \mathrm{~m}$ ). We observed that forest cover at $800 \mathrm{~m}$ landscape extent was highly correlated with forest cover in the two other 
1 considered extents (R2 > 0.90), and thus we maintained only this extent for further

2 analyses.

The forest edge distance is calculated using the Euclidean distance (straight-line distance between any forest pixel and the nearest forest edge), obtained by Spatial Analyst in ArcGIS 10.2 (Figure 2) with a 5 meters pixel size raster (the same pixel size of the forest cover mapping).

\subsection{Terrain explanatory variables (elevation, aspect and terrain slope)}

The elevation, aspect and terrain slope were obtained through the digital terrain model (DTM) generated from the LiDAR data by GEOID (see item 2.2). Those metrics were also extracted with a 5 m pixel resolution using 3D Spatial Analyst in ArcGIS 10.2.

\subsection{Forest age estimation}

We used a forest age estimation calculated by a chronological sequence mapping of Landsat images obtained annually from 1985 to 2017 (http://mapbiomas.org/pages/database/mapbiomas_collection_download/). The final map consists of forest age classification of 4 to 28 years, and equal or superior to 29 years. To classify between younger and older forests, we grouped forest with less than 28 years as younger forests and forests with more than 28 years as older forests. We found that $5 \%$ of the forest cover in the Cantareira study areas and $0.06 \%$ of the forests in the Conduru study area represent younger forests.

\subsection{Relative variable importance calculation}


To test the relative importance of the landscape (forest cover and edge effect) and topographic variables, we performed model selection using Akaike Criterion Information (AICc). We used GLMM with a log-normal distribution, the "glmer" function in the "lme4" package in r version 3.3 (Development Core Team, 2018). Because we suppose that younger and older forests respond to local and landscape-level processes differently (question n. 3), and that landscape history and conservation status can influence those relationships, we performed model selections considering four distinct conditions (treatment groups): i) younger forest of Cantareira; ii) older forest of Cantareira; iii) younger forest of Conduru; iv) older forest of Conduru).

Since the sample points are 25 meters of distance each other, we calculated a covariable of spatial correlation to test the relative variable weight of the other explanatory variables, considering the spatial correlation. We used the "autocov_dis" function from the spdep package in $\mathrm{r}$. AC was computed from the weighted average distance of all neighboring samples, indicating the degree of spatial clustering among dependent variables. The spatial correlation variable was calculated to all the sample points and incorporated into the full model.

We used the "dredge" function from the MuMIn package in $r$, starting with a full model that included all explanatory variables: landscape variables (forest cover and edge distance), terrain variables (elevation, aspect, and slope) and forest age - only to younger forests (4-28 years). We then calculated the relative variable importance for each variable between plausible models with $\Delta$ AICc $<2$, by "model average" function from the MuMIn package. We summed the total weight of all variables and calculated the relative 
variable weight of each variable, in other words, the sum of these variable weights is equal to one.

\section{Results}

The Cantareira and Conduru regions showed distinct patterns to the explanatory variables. Firstly, Cantareira has 7.7 ha of younger forest and 148.9 ha of older forest, while Conduru has 18.7 ha of younger forest and 2935.9 ha of older forest. Forest cover average of sample points (800-buffer ratio) from Cantareira is $38.2 \%$, with a range of 12.9-63.4\%, while the forest cover average of sample points from Conduru is $89.1 \%$, with a range of $27-100 \%$. The maximum edge distance average of Cantareira reaches 157 $\mathrm{m}$ (average of $26.9 \mathrm{~m}$ ), while in Conduru the maximum edge distance is $1192.7 \mathrm{~m}$, (average of $297.3 \mathrm{~m}$ ). Only forest age has the same range between both study regions (428 years), and similar averages: 19.24 years in Cantareira and 17.38 years in Conduru.

The MCH (height at which 95\% of LiDAR returns are below) is fairly similar between the treatment groups $(9,8 \mathrm{~m}$ for the younger forests, against $10,3 \mathrm{~m}$ for older forest) in the Cantareira region (Figure 2). Comparatively, in the Conduru region, the difference between younger ( mean $=9,3 \mathrm{~m})$ and older $($ mean $=14,9 \mathrm{~m})$ forests is relatively high $(60 \%)$.

Edge distance and forest cover are the most relevant factors affecting positively tree height and thus forest biomass for all treatment groups (Figure 3). As a consequence, landscape factors are relatively more important than terrain variables and age, especially in Cantareira and Conduru older forests (Figure 3). The relative importance of variables is quite similar among treatment groups, except for younger forests in Cantareira, where forest age is also an important variable (Figure 3). 
2 for both younger and older forests of Conduru (Figure 4C), but with a low effect in

3 Cantareira (Figure 4A). In both regions, older forest tended to have higher values in

4 areas distant from forest edges, while the effect in regenerating forest is only positive in

5 Conduru (Figure 4, B and D). In the Cantareira region, we can observe an inverted edge

6 effect: in areas distant to forest edges ( $>50 \mathrm{~m})$, regenerating forests present lower

7 biomass $(\mathrm{MCH})$ when compared to areas near $(<40-50 \mathrm{~m})$ from forest edges (Figure $4 \mathrm{~B})$.

8 In the Conduru region, this inverted effect is not observed, and both regenerating and

9 older forests present increases in biomass (MCH) as a forest is located more distant from edges (Figure 4D).

\section{Discussion}

Landscape-level processes related to edge and forest cover effects were the main factors explaining variation in forest biomass (here represented by $\mathrm{MCH}$ ) in the studied fragmented landscapes. Indeed, the importance of those variables far exceeds those of more traditional and well-recognized variables, such as forest age and topography variables. As highlighted in our results, landscape-level factors acting on forests under regeneration, as the one tested here, may affect the speed of forest growth and, consequently, the ability of those forests to store carbon in human-dominated landscapes (Melito, 2016; Melito et al., 2018). Such landscape context processes may have large implications on ecosystem functions related to forest structure and carbon storage.

Although the relative importance of variables was similar among all treatment groups, landscape variables influences were distinct between study regions. Forests in a 
1 regional context of high forest cover (Conduru, > 80\%) presented higher biomass, but were less affected by landscape-level forest cover increase (biomass were mostly maintained high), while forests in a low regional forest cover (Cantareira, 20-30\%) had lower biomass and were more positively affected by forest increase. Biomass was positively affected by distance to edge, except for regenerating forest in Cantareira, suggesting that fragmentation can, in some situations, favor forest regeneration. Beyond the positive contribution of nearby forest fragments to facilitate forest regeneration (Guevara et al., 1992; Guevara and Laborde, 1993; Galindo-Gonzalez et al., 2000), landscapes with more forest cover are also less densely populated and thus less affected by human disturbances, supporting the accumulation of carbon. Human activities on the remaining forest include changes in the overall amount of standing stock (i.e. AGB) and changes in structure, through selective removal of certain species, while others find the opportunity to regenerate in human-dominated landscapes. Where human pressure is greater as a result of accessibility to roads and human settlements (Salinas-Melgoza et al., 2018), there is obviously more likelihood of direct or indirect impact on natural vegetation (Cincotta et al. 2000, Luoga et al. 2002, Mon et al. 2012, Malhi et al. 2014, Morales-Barquero et al. 2015). Landscape-level processes are thus interacting with human activities and terrain factors to regulate biomass in tropical fragmented landscapes.

Natural regeneration of forests is widely considered to be an effective low-cost mechanism for carbon sequestration, particularly in tropical regions (Canadell and Raupachet, 2008; Pan et al., 2011; Houghton et al., 2015). However, this contribution could be distinct in younger and older forests. A new forest edges, after the stabilization of shade-tolerant species mortality, above-ground biomass may increase by the 
1 proliferation of pioneers and lianas, but this effect should be insufficient to compensate

2 losses related to the period of sharp biomass decrease (Melito et al., 2018). Such effects

3 are predicted for remaining older forests affected by deforestation and fragmentation

4 but not for younger forest patches regenerating in a fragmented and human-dominated

5 context, which seems to be the situation of landscapes with a long history of human

6 disturbances. younger forests regenerating in fragmented landscapes are accumulating

7 carbon near the edges where photosynthetic activities are more intense. Those areas can

8 have higher tree height and density of shade-tolerant species with higher wood density

9 (Romitelli et al., chapter 1). Nevertheless, the different mechanisms related to edge

effects which could affect biomass in the younger and older forest must be explored by a systematic and paired design to test the consistency of the observed inverted edge effects in younger and older forests.

\section{Conclusion}

Here, we provide a comprehensive analysis of landscape factors effects on forest growth and above-ground biomass of tropical fragmented forests in contrasting landscape contexts beyond the topography and forest age influence fared well explored. The effect of forest cover on carbon stock was consistently positive, as expected. However, the edge distance influence on forest growth presented contrasting resulting, indicating that there is still a remaining knowledge gap concerning the edge effect mechanisms in younger and old forests.

Given the continued tropical forest fragmentation, landscape-level processes will play an important role in carbon sequestration and its feedback with climate (Reinmann and Hutyra, 2017). New models of biomass estimation need to better incorporate those 
1 processes in addition to commonly used abiotic proxies, through spatially-explicit approaches that consider the spatial arrangement of the remaining forest. Our findings contribute therefore to stimulate initiatives for carbon conservation and regeneration considering the distinct effects that landscape processes can have on younger and older forests.

Even though the actual young forest proportion of Atlantic forest is relatively low (6,78\%; MapBiomas Project, 2019), around 700,000 ha of native forests has been restored from 2011 to 2015 in the Atlantic Forest, and expect that a total of 1.35-1.48 Mha will be under recovery by 2020 (Crouzeilles et al., 2019). Some Payment for Ecosystem Services programs and other initiatives to restore forest cover of Atlantic forest aim to recover more than 15 million hectares until 2050 (Pacto, 2019). This value represents almost $50 \%$ of the current forest cover of the Atlantic forest with less than 30 years old which increased $70 \%$ of the proportion of young forests. Further, in the face of optimizing restoration efforts, in this restoration projects of Atlantic forest for example, our results suggest that forest restoration projects around existing forest old-growths can both reduce edge effects in old-growth patches and favor biomass regrowth in regenerating or restored forests, being thus doubly beneficial to increase carbon stock in human-dominated landscapes.

\section{Acknowledgments}

We thank all landowners for permitting to conduct fieldwork on their lands and for the outstanding support. This study was developed within the "Interface Project", supported by São Paulo Research Foundation (FAPESP, 2013/23457-6). I.R. was supported by a doctorate's fellowship from the Brazilian Ministry of Education (CAPES-DS, 2015-2019). 
2 Becknell, J.M., Keller, M., Piotto, D., Longo, M., dos-Santos, M.N., Scaranello, M.A.,

3 Cavalcante, R.B.O., Porder, S. 2018. Landscape-scale lidar analysis of aboveground biomass distribution in secondary Brazilian Atlantic Forest. Biotropica, 50 (3), 520530. (12), 3713-3726.

Brown, S., Lugo, A.E. 1990. Tropical secondary forests. J. Trop. Ecol. 6, 1-31.

Canadell, J.G. and Raupach, M.R. 2008. Managing forests for climate change mitigation. Science 320, pp. 1456-1457.

Castilho, C.V., Magnusson, W.E. R., de Araújo, N.O., Luizão, R.C.C., Luizão, F.J., Lima, A.P., Higuchi, N. 2006. Variation in aboveground tree live biomass in a central Amazonian Forest: Effects of soil and topography. For. Ecol. Manag. 234, 85-96.

Chazdon, R. L. Second Growth: The Promise Of Tropical Forest Regeneration In An Age Of Deforestation. (University of Chicago Press, 2014.

Cincotta, R.P., Wisnewski, J., Engelman, R. 2000. Human population in the biodiversity hotspots. Nature 404, pp.:990-992.

Costa, K.M. 2015. O estoque de carbono na vegetação e no solo em fragmentos florestais de paisagens tropicais. São Paulo University, 66 pp. 
1 Crouzeilles, R., Santiami, E., Rosa, M., Pugliese, L., Brancalion, P.H.S., Rodrigues, R.R., Metzger, J.P., Calmon, M., Scaramuzza, C.A.M., Matsumoto, M.H., Padovezi, A., Benini, R.B., Chaves, R.B., Metzker, T., Fernandes, R.B., Scarano, F.R., Schmitt, J., Lui, G., Christ, P., Vieira, R.M., Senta, M.M.D., Malaguti, G.A., Strassburg, B.B.N., Pinto, S. 2019. There is hope for achieving ambitious Atlantic Forest restoration commitments. Perspectives in Ecology and Conservation, 17 (2), pp. 80-83.

d'Albertas, F., Costa, K., Romitelli, I., Barbosa, J.M., Vieira, S.A., Metzger, J.P. 2018. Lack of evidence of edge age and additive edge effects on carbon stocks in a tropical forest. For. Ecol. Manage 407(1), 57-65.

D’Angelo, S., Andrade, A., Laurance, S.G., Laurance, W.F., Mesquita, R., 2004. Inferred causes of tree mortality in fragmented and intact Amazonian forests. J. Trop. Ecol. 20, 243-246.

Didham, R.K., Lawton, J.H. 1999. Edge structure determines the magnitude of changes in microclimate and vegetation structure in tropical forest fragments. Biotropica, 31, pp.17-30.

Galindo-Gonzalez, J., Guevara, S., Sosa, V. 2000. Bat- and bird-generated seed rains at isolated trees in pastures in a tropical rainforest. Conserv. Biol. 14, 1693-1703.

Gallardo-Cruz, J. A., Pérez-García, E.A., Meave, J.A. 2009. b-Diversity and vegetation structure as influenced by slope aspect and altitude in a seasonally dry tropical landscape. Landscape Ecology 24, pp. 473-482.

Gouvêa, J.B.S., Mattos Silva, L.A., Hori, M. 1976. Fitogeografia.In: Comissão Executiva do Plano da Lavoura Cacaueira and the Instituto interamericano de Ciências Agricolas- 
1 OEA. Diagnostico socioeconômico da região cacaueira, vol 7. Recursos Florestais,

2 Ilhéus, Bahia, Brazil, pp 1-7.

3 Guariguata, M.,Ostertag, R. 2001. Neotropical secondary forest succession: Changes in structural and functional characteristics. Forest Ecology and Management 148:185206.

Guevara, S., Laborde, J. 1993. Monitoring seed dispersal at isolated standing trees in tropical pastures - consequences for local species availability. Veget. 108, 319-338.

Guevara, S., Laborde, J., Sanchez-Rios, G. 2004. Rainforest regeneration beneath the canopy of fig trees isolated in pastures of Los Tuxtlas, Mexico. Biotropica 36, 99-108.

Haddad, N.M., Brudvig, L.A., Clobert, J., Davies, K.F., Gonzalez, A, Holt, R.D., Lovejoy, T.E., Sexton, J.O., Austin, M.P., Collins, C.D., Cook, W.M., Damschen, E.I., Ewers, R.M., Foster, B.L., Jenkins, C.N., King, A.J., Laurance, W.F., Levey, D.J., Margules, C.R., Melbourne, B.A., Nichols, A.O., Orrock, J.L., Song, D, Townshend, J.R. 2015. Habitat fragmentation and its lasting impact on Earth's ecosystems. Science Advances, 1(2), e1500052.

Homeier, J., Breckle, W.S., Gunter, S., Rollenbeck, R.T., Leuschner, C. 2010. Tree diversity, forest structure and productivity along altitudinal and topographical gradients in a species-rich Ecuadorian montane rain forest. Biotropica 42, pp.140-148.

Houghton, R.,Byers, B., Nassikas, A. 2015. A role for tropical forests in stabilizing atmospheric C02. Nature Climate Change. 5. 1022-1023.

IBGE, 2012. Manual técnico da vegetação brasileira. Instituto Brasileiro de Geografia e Estatística 1, 271. https://biblioteca.ibge.gov.br/visualizacao/livros/liv63011.pdf. 
1 Joly, C.A., Metzger, J.P., Tabarelli, M. 2014. Experiences from the Brazilian Atlantic Forest: ecological findings and conservation initiatives. New Phytol. 204459-73.

Landau, E.C. 2003. Normais de Precipitação no Sudeste da Bahia, Brasil. CD-ROM In Prado PI, Landau EC, MouraRT, Pinto LPS, Fonseca GAB, Alger K (orgs.) Corredor de Biodiversidade da Mata Atla^ntica do Sul da Bahia.IESB/CI/CABS/UFMG/UNICAMP,

$6 \quad$ Ilhéus, Bahia, Brazil

Laurance, W.F., Laurance, S.G., Ferreira, L.V., Rankinde Merona, J.M., Gascon, C., Lovejoy, T.E. 1997. Biomass collapse in Amazonian forest fragments. Science 278, 1117-1118.

Laurance, W.F., Perez-Salicrup, D., Delamonica, P., Fearnside, P.M., D’Angelo, S., Jerozolinski, A., Pohl, L., Lovejoy, T.E. 2001. Rainforest fragmentation and the structure of Amazonian liana communities. Ecology 82, 105-116.

Laurance, W.F., Camargo, J.L.C., Luizão, R.C.C., Laurance, S.G., Pimm, S.L., Bruna, E.M., Stouffer, P.C., Williamson, G.B., Benítez-Malvido, J., Vasconcelos, H.L., Van Houtan, K.S., Zartman, S.E., Boyle, S.A., Didham, R.K., Andrade, A., Lovejoy, T.E. 2011. The fate of Amazonian forest fragments: A 32-year investigation. Biol. Conserv. 144, 56-67.

Leitold, V., Keller, M., Morton, D.C., Cook, B.D., Shimabukuro, Y.E. 2015. Airborne lidarbased estimates of tropical forest structure in complex terrain: opportunities and trade-offs for REDD+. Carbon Balance and Management 10:3, pp.1-12.

Lôbo, D., Leão, T., Melo, F. P. L., Santos, A., Tabarelli, M. 2011. Forest fragmentation drives Atlantic forest of northeastern Brazil to biotic homogenization. Diversity and Distributions, 17, 287-296. 
1 Luoga, E. J., E. Witkowski, and K. K. Balkwill. 2002. Harvested and standing wood stocks

2 in protected and communal miombo woodlands of eastern Tanzania. Forest Ecology 3 and Management 164:15-30.

4 Malhi, Y., T. A. Gardner, G. R. Goldsmith, M. R. Silman, and P. Zelazowski. 2014. Tropical 5 forests in the Anthropocene. Annual Review of Environment and Resources 39:125$6 \quad 159$.

$7 \quad$ MapBiomas Project. Collection 3.1 of the Annual Series of Coverage and Land Use Maps of Brazil, accessed on 12/20/2018 through the link: http://mapbiomas.org.

Melito, M., Metzger, J.P., de Oliveira, A.A. 2018. Landscape-level effects on aboveground biomass of tropical forests: a conceptual framework. Glob. Change Biol. 24: 597-607.

Michalski, F., Nishi, I., Peres, C. A. 2007. Disturbance-mediated drift in tree functional groups in Amazonian forest fragments. Biotropica,39, 691-701.

Mon, M.S., Mizoue, N., Htun, Z., Kajisa, T., Yoshida, S. 2012. Factors affecting deforestation and forest degradation in selectively logged production forest: a case study in Myanmar. Forest Ecology and Management 267, pp.190-198.

Morales-Barquero, L., Borrego, A.,Skutsch, M., Kleinn, C., Healey, J.R. 2015. Identification and quantification of drivers of forest degradation in tropical dry forests: a case study in Western Mexico. Land Use Policy 49, pp. 296-309.

Naughton-treves, L., Chapman, C. 2002. Fuelwood Resources and Forest Regeneration on Fallow Land in Uganda. Journal of Sustainable Forestry. 14. 19-32. 
1 Pan, Y., Birdsey, R.A., Fang, J., Houghton, R., Kauppi, P.E., Kurz, W.A., Phillips, O.L.,

2 Shvidenko, A., Lewis, S.L., Canadell, J.G., Ciais, P., Jackson, R.B., Pacala, S.W., McGuire, A.D., Piao, S., Rautiainen, A., Sitch, S., Hayes, D. 2011. A large and persistent carbon sink in the world's forests. Science 333, 988-993.

R Development Core Team. 2018. R: A language and environment for statistical computing. R Foundation for Statistical Computing, Vienna, Austria. ISBN 3-90005107-0, Available in: URL http://www.R-project.org.

8 Poorter, L., Bongers, F., Aide, T.M., et al. 2016. Biomass resilience of Neotropical secondary forests. Nature 530, 212-225.

Pütz, S., Groeneveld, J., Alves, L.F., Metzger, J.P., Huth, A. 2011. Fragmentation drives tropical forest fragments to early successional states: a modeling study for Brazilian Atlantic forests. Ecol. Model. 222, 1986-1997.

Reinmann, A.B., Hutyra, L.B. 2017. Edge effects enhance carbon uptake and its vulnerability to climate change in temperate broadleaf forests. PNAS 114 (1), pp. 107112.

Rezende, C.L., Scarano, F.R., Assadd, E.D., Joly, C.A., Metzger, J.P., Strassburgg, B.B.N., Tabarelli, M., Fonseca, G.A., Mittermeier, R.A. 2018. From hotspot to hopespot: An opportunity for the Brazilian Atlantic Forest. Perspectives in Ecology and Conservation, 16 (4), pp. 208-214.Ribeiro, M.C., Metzger, J.P., Martensen, A.C., Ponzoni, F.J., Hirota, M.M., 2009. The Brazilian Atlantic Forest: How much is left, and how is the remaining forest distributed? Implications for conservation. Biol. Conserv. 142, 11411153. 
1 Ribeiro, M.C., Metzger, J.P., Martensen, A.C., Ponzoni, F.J., Hirota, M.M., 2009. The Brazilian

2 Atlantic Forest: How much is left, and how is the remaining forest distributed?

3 Implications for conservation. Biol. Conserv. 142, 1141-1153.

4 Rodrigues, R.R., Joly, C.A., Brito, M.C.W., Paese, A., Metzger, J.P., Cassati, L., Nalon, M.A.,

5 Menezes, N., Ivanauskas, N.M., Bolzani, V., Bononi, V.L.R. 2008. Diretrizes para

6 conservação e restauração da biodiversidade no Estado de São Paulo. Governo do

7 Estado de São Paulo, São Paulo.

8 Romitelli, I., D'Albertas, F., Costa, K., Vieira, S.A., Metzger, J.P. Tropical forests in human-

9 dominated landscapes present low biomass stocks and high spatial variability

10 (submitted.)

Romitelli, I., Barbosa, J.M., Keller, M., Metzger, J.P. Unexpected edge effect pattern on carbon stocks in secondary tropical forests (in preparation)

Salinas-Melgoza, M. A., Skutsch, M., Lovett, J.C. 2018. Predicting aboveground forest biomass with topographic variables in human-impacted tropical dry forest landscapes. Ecosphere 9(1), PP. 1-20.

Slocum, M. G. 2001. How tree species differ as recruitment foci in a tropical pasture. Ecology 82:2547-2559.

Slocum, M. G., and C. C. Horvitz. 2000. Seed arrival under different genera of trees in a neotropical pasture. Plant Ecology 149:51-62. 
1 Smith, I.A., Hutyra, L.R., Reinmann, A.B., Marrs, J.K., Thompson, J.R. 2018. Piecing

2 together the fragments: elucidating edge effects on forest carbon dynamics. Frontiers

3 in Ecology Environmental, 16(4), pp. 213-221.

4 Sundqvist, M. K., Sanders, N.J., Wardle, D.A.2013. Community and ecosystem responses to

5 elevational gradients: processes, mechanisms, and insights for global change. Annual

6 Review of Ecology, Evolution and Systematics 44, pp. 261-280.

7 Tabarelli, M., Peres, C. A., Melo, F. P. L. 2012. The "few winners and many losers"

8 paradigm revisited: Emerging prospects for tropical forest biodiversity. Biological

9 Conservation, $155,136-140$.

Wasser, L., Day, R., Chasmer, L., Taylor, A. 2013. Influence of Vegetation Structure on Lidar-derived Canopy Height and Fractional Cover in Forested Riparian Buffers During Leaf-Off and Leaf-On Conditions. PLoS One 8(1).

Whately, M., Cunha, P. 2006. Um olhar sobre o maior manancial de água da Região Metropolitana de São Paulo. In. Instituto Socioambiental São Paulo. Wilson, J. P., Gallant, J.C. 2000. Terrain analysis:principles and applications. John Wiley \& Sons, New York, New York, USA 

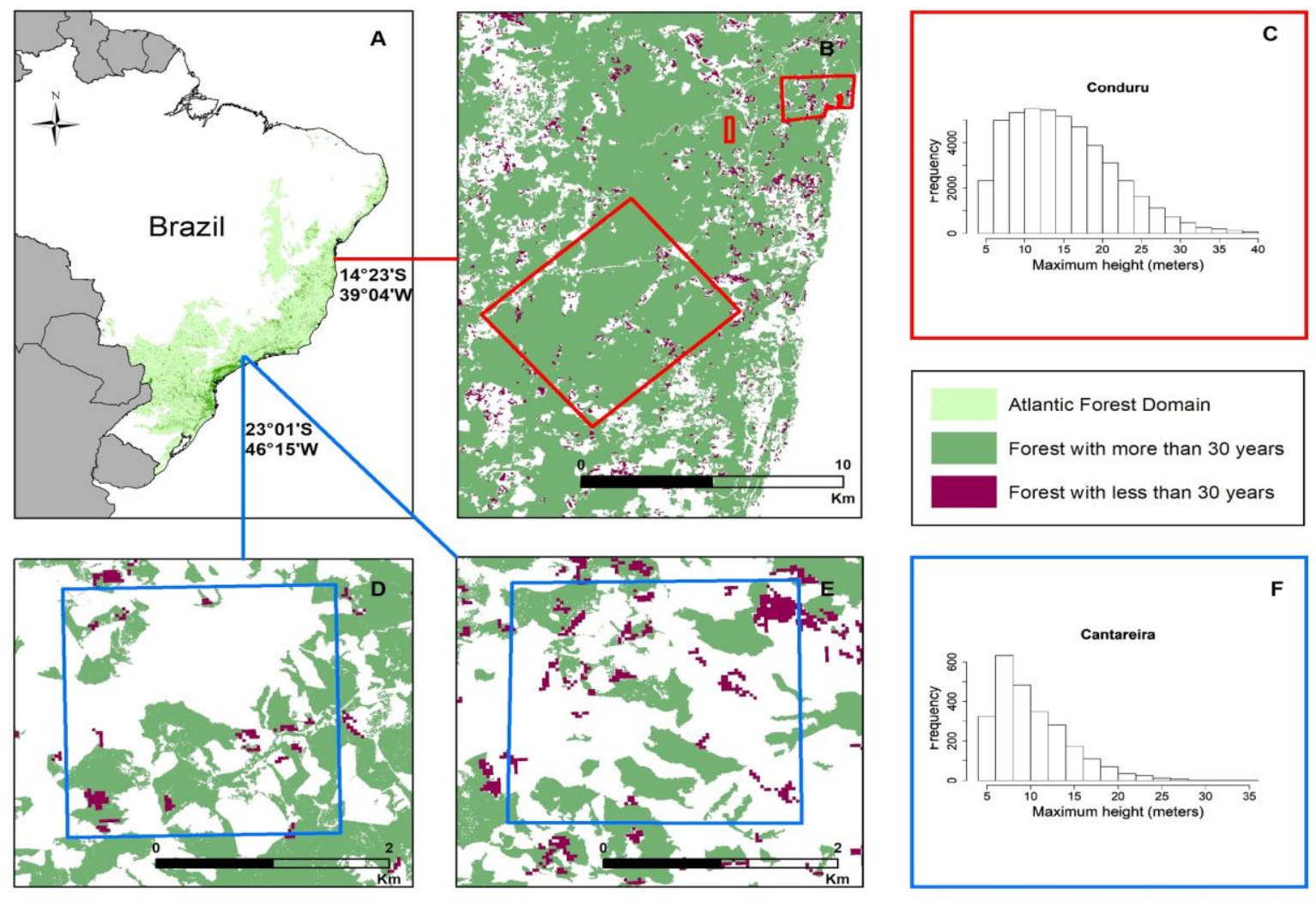

2 Figure 1. Study areas situated in the Southeast and Northeast of Brazil (A). The two

3 study regions (Conduru - panel B and Cantareira - panels D and E) include an area with

4 large variation in forest cover. Panels $\mathrm{E}$ and $\mathrm{F}$ show the histogram of the maximum

5 canopy height of Conduru and Cantareira, respectively 


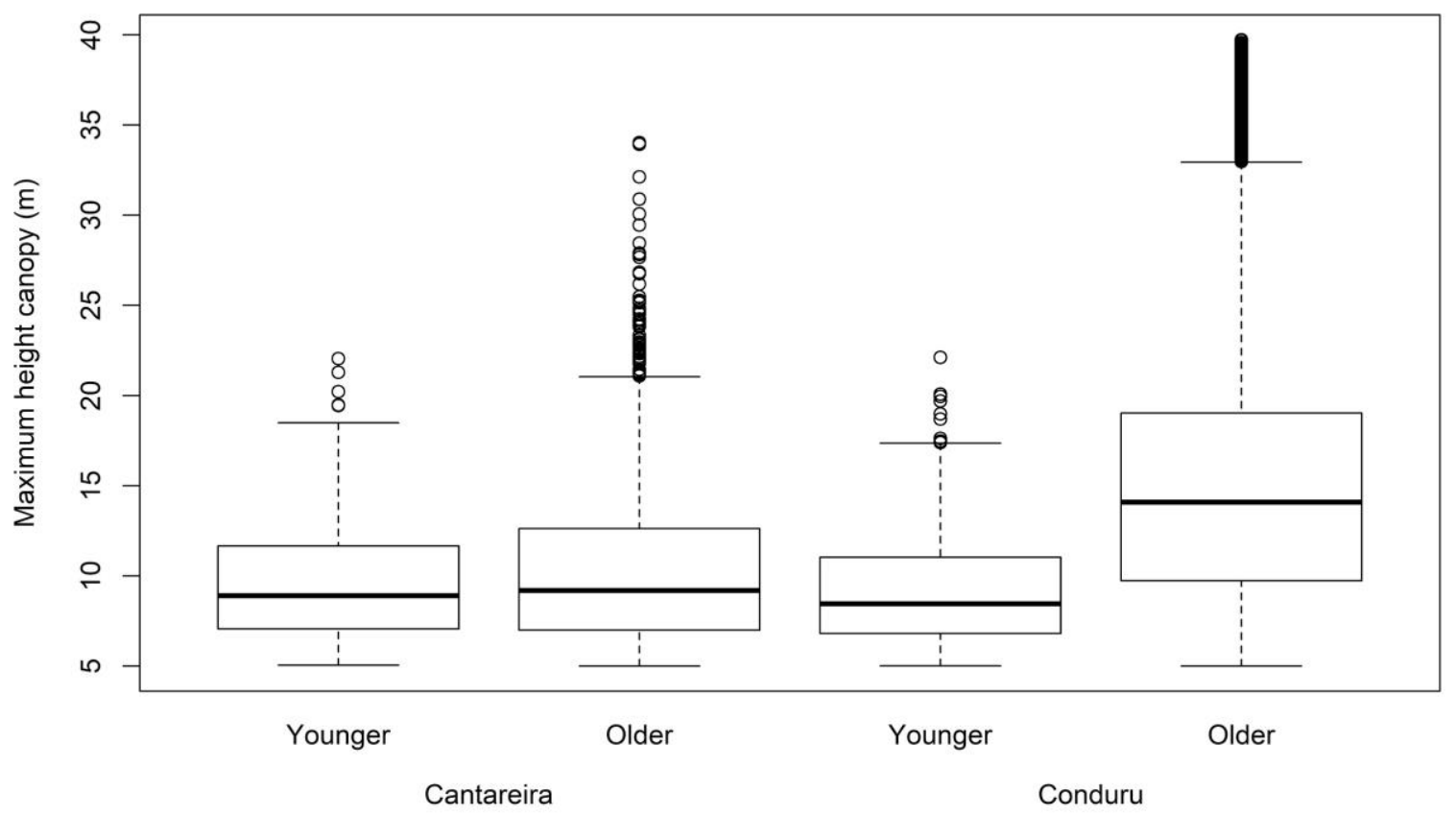

1

2 Figure 2. Boxplot of MCH by succession forest group and study region (Cantareira and

3 Conduru). The Younger group corresponds to forests with less than 30 years and the

$4 \quad$ Older group corresponds to forests with more than 30 years 


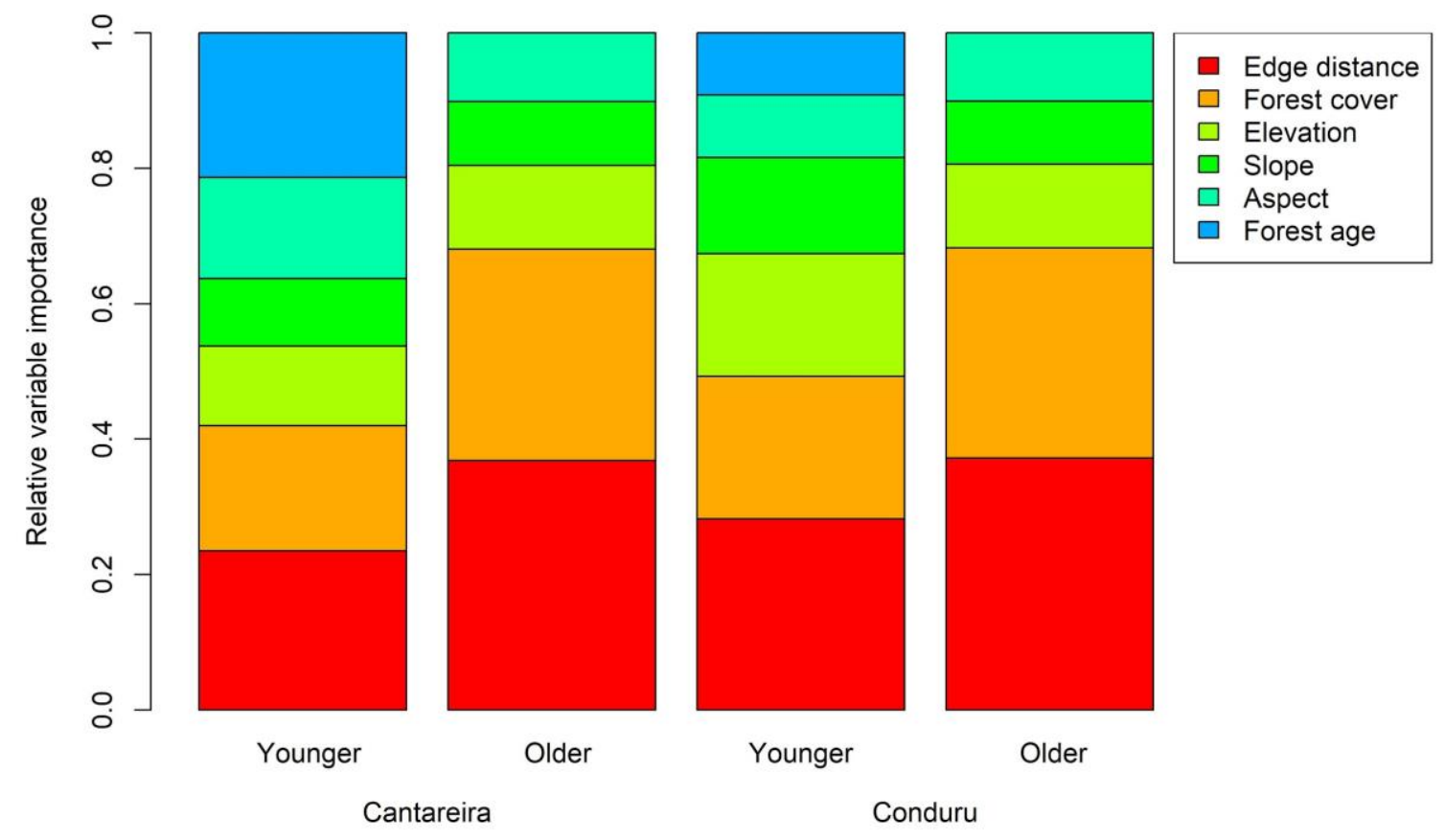

3 Figure 3. Relative variable importance of all variables tested: edge distance, forest cover,

4 elevation, slope, aspect and forest age in young and old-growth forests of Cantareira and

5 Conduru region. The Younger group corresponds to forests with less than 30 years and

6 the Older group corresponds to forests with more than 30 years. 

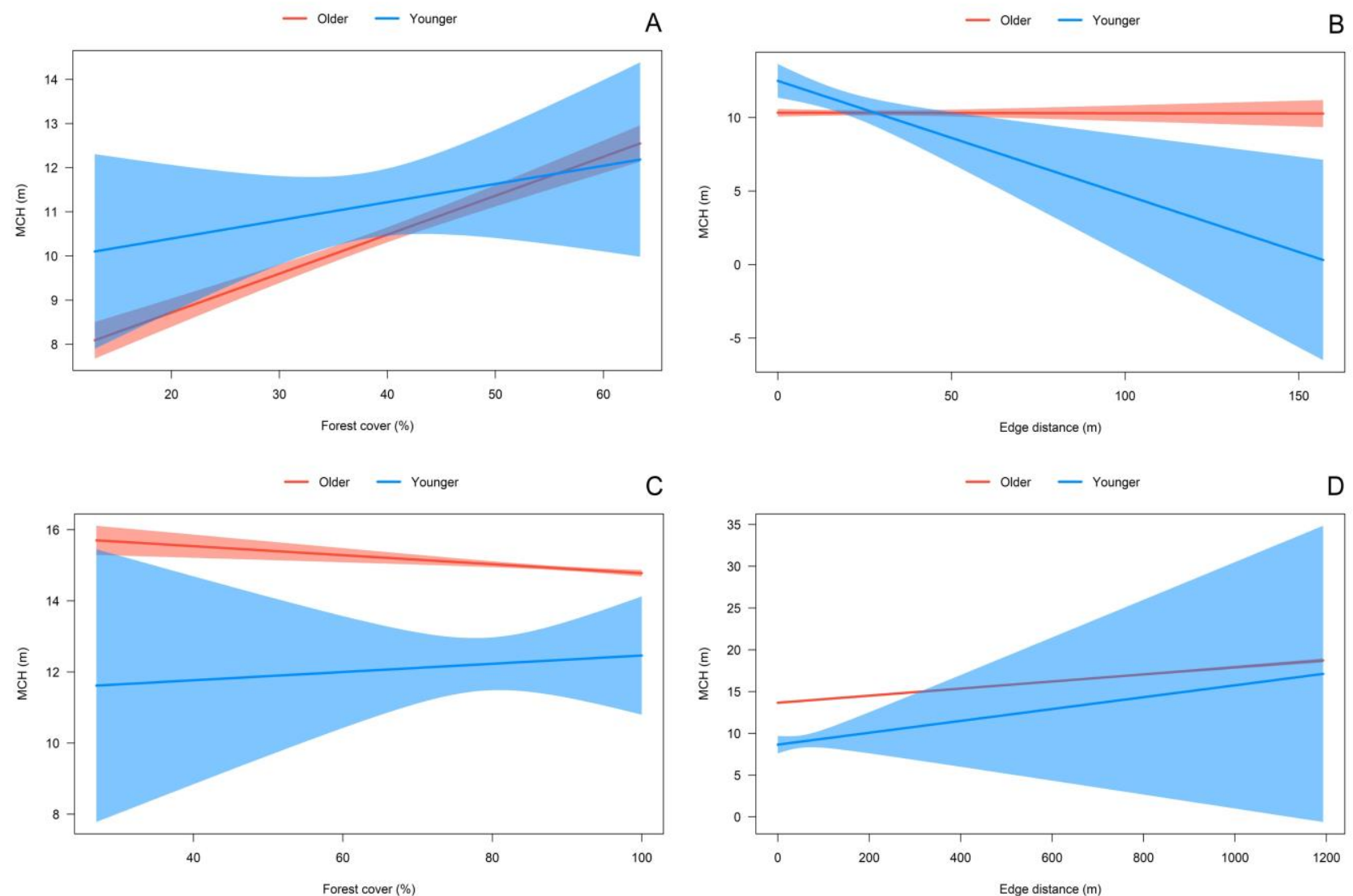

1

2

3 Figure 4. Relationship of MCH (height at which 95\% of LiDAR returns are below) with

4 forest cover and edge distance in Cantareira (panels A and B) and Conduru (panels C and

5 D) regions. The Younger group corresponds to forests with less than 30 years and the

6 Older group corresponds to forests with more than 30 years. 
1 Capítulo 3: “Contrasting edge effects over successional stages in

2 secondary tropical forests"

3 Isabella Romitelli, Jomar Magalhães Barbosa and Jean Paul Metzger

\section{ABSTRACT}

5 Deforestation and fragmentation are the most important drivers of 6 environmental changes in tropical forest regions, resulting in landscapes with 7 extensive edges between anthropic and forest areas. The biotic and abiotic 8 characteristics of those edge areas can affect forest structure and productivity, 9 but the distinct effects that edges can have on older and initial regenerating forests are still poorly explored. This study is the first to test, systematically and with a paired design, the edge effect on forest structure of older and regenerating forests. We hypothesize that biomass are negatively affected by edges in older forests (through disturbance effects and loss of old trees), while positively affected in regenerating forests (through favorable photosynthetic conditions and faster growth of trees). To test this hypothesis, we used LiDAR data of maximum canopy height $(\mathrm{MCH})$, as a biomass proxy, from two fragmented landscapes of the Brazilian Atlantic Forest. Using maps of $\mathrm{MCH}$ values, we built "virtual transects" of $100 \mathrm{~m}$ from edges to the interior of the forest, and compared, with generalized linear mixed models, the effects of edge on older and regenerating forests with a paired design. As expected, edges affected negatively tree height in older forests (i.e. lower biomass near edges) and positively in regenerating areas (i.e. higher biomass near edges). The slope of the relationship between MCH and edge distance is mostly affected by forest age, but forest cover surrounding a particular area also plays a positive significant role on tree height. Given the continued trend of forest fragmentation and the important role of edge effects on modulating terrestrial carbon sink, further landscape planning projects should be delineated considering the aspects abovementioned to provide better climate regulation. 
1 In this sense, our results suggest that forest restoration projects around 2 existing forest olders can both reduce edge effects in older patches and favor

3 biomass regrowth in regenerating or restored forests, being thus doubly

4 beneficial to increase carbon stock in human-dominated landscapes.

5 Keywords: human-dominated landscapes, Atlantic forest, carbon stock, above6 ground biomass

\section{Introduction}

Deforestation and fragmentation are the most relevant drivers of ecological changes in human-dominated landscapes. More than $60 \%$ of terrestrial forestlands are already replaced by agriculture and infrastructure (Reinmann and Hutyra, 2017). In addition to this forest reduction, the remaining forest cover is also very fragmented: $70 \%$ is within $1 \mathrm{~km}$ of the edge of anthropic land uses (Remy et al., 2016), and 20\% within 100 meters of the edge (Haddad et al., 2015). The direct and indirect effects of microclimate conditions and higher disturbance regimes along forest edges could be responsible for approximately $10 \%$ of carbon stock reduction in tropical forests Amazonian region (Laurance, 1997).

Forest edges, when compared to interior conditions, are abiotically characterized by high wind turbulence (Laurance, 1997), high temperature and low humidity (Briant et al., 2010), which affects forest community structure and composition (Peters, 2001), and indirectly phenology and plant recruitment (Curran et al.,1999). All those abiotic characteristics may induce 
1 increases, decreases, or no change in the factors controlling forest productivity

2 and biomass in comparison to forest interior (Ries et al., 2004). The extent and the intensity of edge effects associate to the abiotic conditions may vary with

4 vegetation type, successional stage, landscape-context and regional-scale

5 climate conditions (Crouzeilles et al., 2017; Schmidt et al., 2017).

6

Edge conditions can induce changes in forest structure and consequently in carbon stocks (Melito et al. 2018). Theoretically, those effects could be negative or positive. Negative effects have been widely described in the literature (e.g. Laurance et al., 1997; Putz et al., 2014) and are mostly related to higher rates of mortality of large shade-tolerant trees near the edges due to microclimatic and disturbance regime changes. After the stabilization of shadetolerant species mortality, above-ground biomass may increase by the proliferation of pioneers and lianas, indicating that edge condition may benefit the growth of some species. Although this positive effect is insufficient to compensate for losses related to the previous period of sharp biomass decrease (Melito et al., 2018).

Contrastingly, changes at the forest edge can create favorable conditions for plant growth, depending on the local limiting factors to growth and vulnerabilities to stress (Smith et al., 2018). For example, nitrogen deposition and availability can be elevated at the forest edge due to a combination of inputs from nearby fertilizer applications and altered canopy roughness characteristics (Weathers et al., 2001; Remy et al., 2016). Overall, increased 
1 incident solar radiation is perhaps the key factor differentiating the edge's

2 microenvironment from that of the forest interior (Matlack, 1993); the tree seedling recruitment and growth may also increase within $10 \mathrm{~m}$ of a newly created edge (Sizer and Tanner, 1999). All those factors can lead to a positive edge effect on biomass, which is also called "inverted edge effect pattern" (Costa, 2015; Romitelli et al., chapter 1), given that the negative effect is the best-known and widely accepted pattern.

Negative edge effects on biomass were predicted for older forests affected by surrounding deforestation and fragmentation processes, but not for younger forest patches regenerating in a fragmented and human-dominated context. Actually, in new regenerating forests an inverted pattern (i.e. positive edge effect on biomass) should be expected because in this condition of forest regrowth tendency biomass is mostly increasing with regeneration (and not decreasing due to mortality). In addition, the extent of most microenvironmental changes can be two to five times higher in younger forest edges than at older and densely vegetated edges (Didham and Lawton, 1999). Considering that over half of the world's tropical forests are not older, but naturally regenerating forests in initial successional stages (FAO, 2017), we should differentiate both the edge effects on older and regenerating forests to fully account for edge effects in fragmented landscapes.

Although the inverted edge effect pattern in tropical forests has been documented in other recent studies (Reinmann \& Hutyra, 2017; Romitelli et al., 
chapter 1 and 2), here we propose a new systematic and paired design to test the edge effect in older and younger forests. We hypothesized that younger and older forests respond distinctly to edge effects: older will respond negatively to edges (lower biomass near the edge) and younger forests will respond positively (higher biomass near the edge). To test this hypothesis, we used Maximum Canopy Height (MCH) obtained with LiDAR data as a proxy of aboveground biomass and explored edge effects in younger and older forests of two fragmented landscapes from the Brazilian Atlantic Forest.

\section{Methods}

\subsection{LiDAR data and MCH variable calculation}

We obtained data from two regions (Cantareira and Conduru), both located in the Brazilian Atlantic forest (Figure 1A), a highly diverse and endangered tropical forest that experienced unprecedented levels of habitat loss and other human disturbances since the 16th century (Joly et al., 2014). The remaining forest cover in the Brazilian Atlantic forest ( $\sim 28 \%$ of its original distribution; Rezende et al., 2018) consist of small fragments, with $<50$ ha (Ribeiro et al., 2009), including 46\% of this forest at less than $100 \mathrm{~m}$ distant from an edge (Figure 1A; Ribeiro et al., 2009). The two studied regions present contrasting landscape conditions which allowed us to explore the effect of distinct regional contexts on processes that modulate forest regeneration:

Conduru is more forested (approximately $80 \%$ of forest cover) and less disturbed, while Cantareira is less forested (approximately 20\% of forest 
1 cover) and more intensively disturbed. Regenerating forests (with less than 28

2 years) correspond to approximately $1 \%$ of all forests in Conduru and $5 \%$ in

3 Cantareira.

4

The Cantareira study region (Figure 1C-D) is located in Southeast Brazil. It includes an important ecological corridor, which was considered of high priority for biodiversity conservation at the state level (Rodrigues et al., 2008; Joly et al., 2010). Landscapes of the Cantareira-Mantiqueira corridor are very heterogeneous, comprising different land uses, mostly pasture areas in small properties and forestry plantations, especially with Eucalyptus spp. Native Atlantic Forest vegetation, in different successional stages and submitted to different levels of disturbance, represents $21 \%$ of the Cantareira study region (Whately and Cunha, 2006).

The Conduru study region is a protected area (Serra do Conduru State Park) in Southern Bahia, Brazil (Figure 1B). The Conduru area bounds one of the largest contiguous areas of Atlantic forest in the northeast of Brazil (almost 10,000 ha) and includes patches of secondary forest at different stages of regeneration, active forest restoration sites and areas of older forest that have been selectively logged in the past. Selective logging, hunting and fiber harvesting are common throughout the Conduru. Some small patches within the park remain occupied with pastures. Several frequently used roads bisect the protected area and there are trails used by local inhabitants throughout the area (Becknell et al., 2018). 

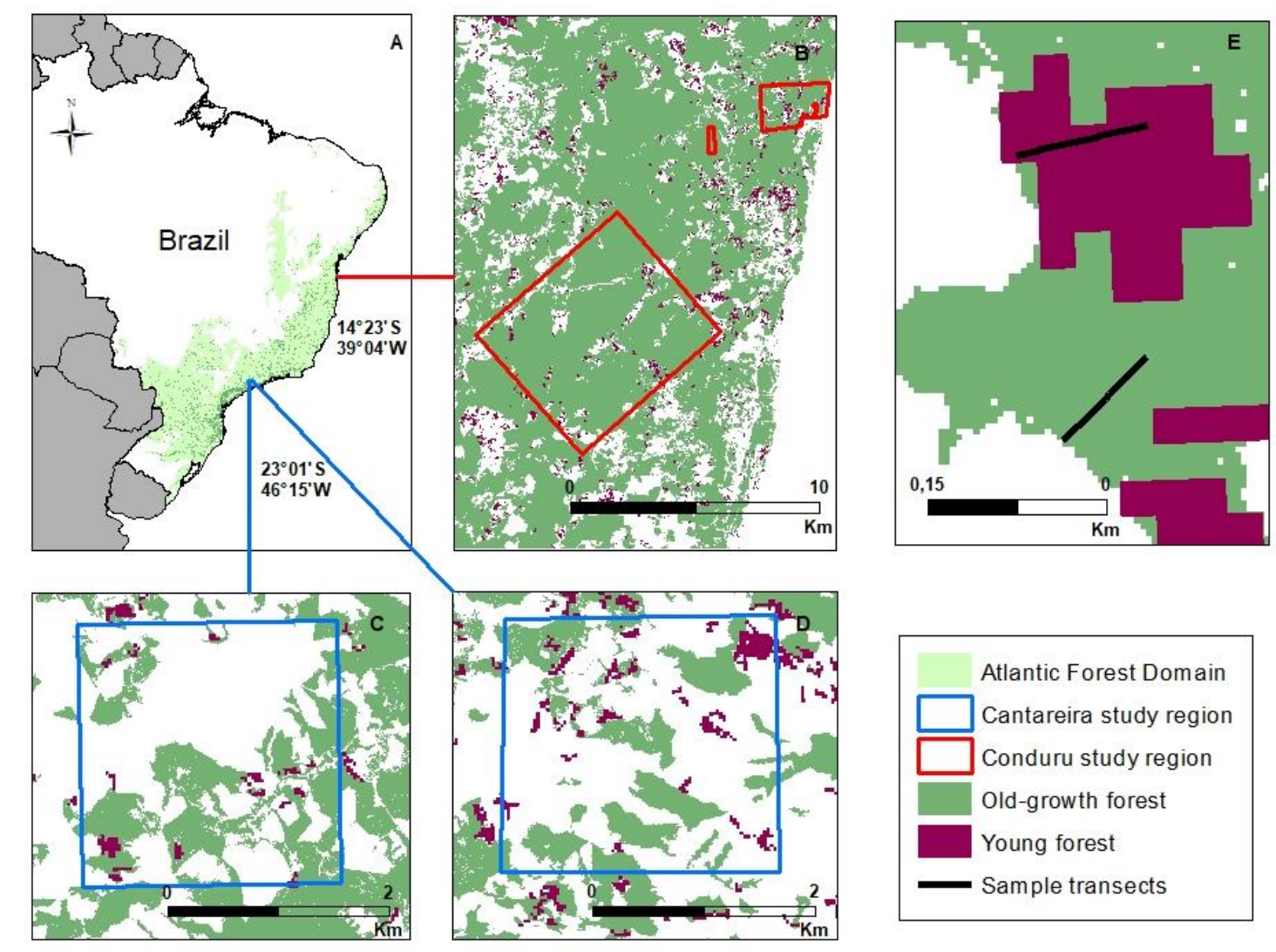

1

2 Figure 1. Study areas situated in the Southeast and Northeast of Brazil (A). The 3 two study regions (Conduru - panel B and Cantareira - panels C and D) embrace large variation in forest cover. Panel E shows an example of a virtual sample transect in older and younger forest.

\subsection{LiDAR data and MCH variable calculation}

Although small plot-scale studies are crucial for measuring many important variables including species density and soil properties (Becknell et al., 2018), airborne LiDAR offers an alternative for quantification of forest structure at larger spatial scales (Leitold et al., 2015). LiDAR data provide direct measurements of height, which can be used to generate estimates of forest biomass (e.g. Lefsky et al., 2002; Asner and Mascaro, 2014). 
The LiDAR data of the Cantareira study region was acquired in October 2014 by an airplane flight with an Optech Orion M300 sensor at an altitude of 853 meters, with a field of view of $10^{\circ}$. Laser-spot spacing was maintained at approximately 86 laser shots $\mathrm{m}^{-2}$. The LiDAR dataset covers two areas of 499 hectares each (35 km distant apart), which includes approximately $43 \%$ of native forest vegetation. In Conduru region, the LiDAR data was acquired in December 2015 by an airplane flight with an Optech Orion M300 sensor at an altitude of 853 meters, with a field of view of $12^{\circ}$. Laser-spot spacing was maintained at approximately 94 laser shots $\mathrm{m}^{-2}$. This LiDAR dataset covers three areas totaling 4,529 hectares, which includes approximately $82 \%$ of native forest vegetation.

Using the above-mentioned LiDAR data, we calculated the maximum canopy height. The MCH is a good proxy of above-ground biomass in Atlantic Forest (Becknell et al., 2018). In addition, $\mathrm{MCH}$ variable has been used to study forest structure and tree growth (Wasser et al., 2013). For both study regions, digital terrain models (DTM) were generated from the LiDAR data using a methodological process previously described in Leitold et al. (2015). Then, we calculated a 1-m-pixel-scale MCH model using the 95th percentile threshold of the LiDAR data points (P95 tree height map). To calculate the P95, we used the "Cloudmetrics" utility in FUSION software package, beta version derived from version 3.00 (http://forsys.cfr.washington.edu/fusion.html). We used a 1-mpixel mean moving window smoothing function to remove anomalies. 


\section{$1 \quad$ 2.3. Virtual transect sampling}

To systematically test the edge effect with a paired design in older and younger forests, we plotted over the MCH raster maps 20 orthogonal virtual transects on each study region (Cantareira and Conduru), totaling 40 transects (Figure 1E). These transects - with 100 meters of extension - were orthogonally positioned from the forest edge to the interior and constructed by the polyline creation function in ArcGIS 10.2 software. We paired nearby transects in younger and older forests to control for possible biotic and abiotic factors, which could influence the edge effect in biomass (MCH). The paired transects were linked to a same identification number in order to proceed with further statistical analysis. In younger forests, we positioned the transects in areas where forest age was the more homogeneous as possible all long the transects.

We obtained MCH and explanatory variables (forest age and edge distance) in sample points in an interval of 5 meters, totalizing 20 sample points per transect $(100 / 5$ meters $=20$ sample points $)$.

\subsection{Explanatory variables (forest age and edge distance)}

To determine the spatial position of any MCH pixel within the virtual transect, we calculated the Euclidean distance (straight-line distance) between any forest pixel and the nearest forest edge. In this procedure, we applied the Spatial Analyst package of ArcGIS 10.2 (Figure 2) to a 5 meters pixel size raster (the same pixel size of the forest cover mapping). 
2 images obtained annually from 1985 to 2017 (MapBiomas Project; available at http://mapbiomas.org) to determine forest age of all MCH pixels. This forest

4 age map consists of a classification that ranges from 4 to 28 years and equal or 5 superior to 29 years. For the purpose of classifying both younger and older

6 forest, we grouped forest with equal and less than 28 years as younger forests

7 and forests with more than 28 years as older forests. We obtained low younger

8 forest points in comparison to older forests: 4.91\% (7.68 ha) in Cantareira

9 region and $0.06 \%$ (18.68 ha) in Conduru region.

\subsection{Data analyses}

\subsubsection{Mixed linear model}

The MCH value of each forest pixel located at the virtual transects was used as the response variable. To quantify and model the relationships between $\mathrm{MCH}$ and the explanatory variables (forest age and edge distance), we used generalized linear mixed models. The identity of the paired transects was used as random effect in all models. We used the mixed models approach to test edge effect distance since it allows considering the gradual influence of distance, as used by Reinmann and Hutyra (2017). To select the best distribution to fit the MCH data, we performed maximum likelihood estimation with Log-Normal, Normal and Gamma distributions. Then $\mathrm{MCH}$ was normalized to an exponential distribution because this distribution showed the best fit to our data in both study regions (Figure S1). We built simple models in order to evaluate the 
1 individual effects of each explanatory variable (successional stage and edge

2 distance. The pair of virtual transects (i.e. younger and older forests) was

3 considered as a fixed effect in all models. Therefore, the model selection

4 procedure considered firstly the younger-old growth relationship in each pair

5 and then this relation to all other explanatory variables.

6 We selected the most plausible models among the six models tested by

7 the corrected Akaike information criterion (AICc). The AICc is a selection

8 criterion that penalizes models with many parameters and utilizes a correction

9 for small sample sizes (Burnham and Anderson, 2002). Small values of AIC

10 represent the best fit, so models with $\Delta \mathrm{AICc}<2$ were considered equally

11 plausible. The statistical analyses were performed using R software (R

12 Development Core Team, 2019). 

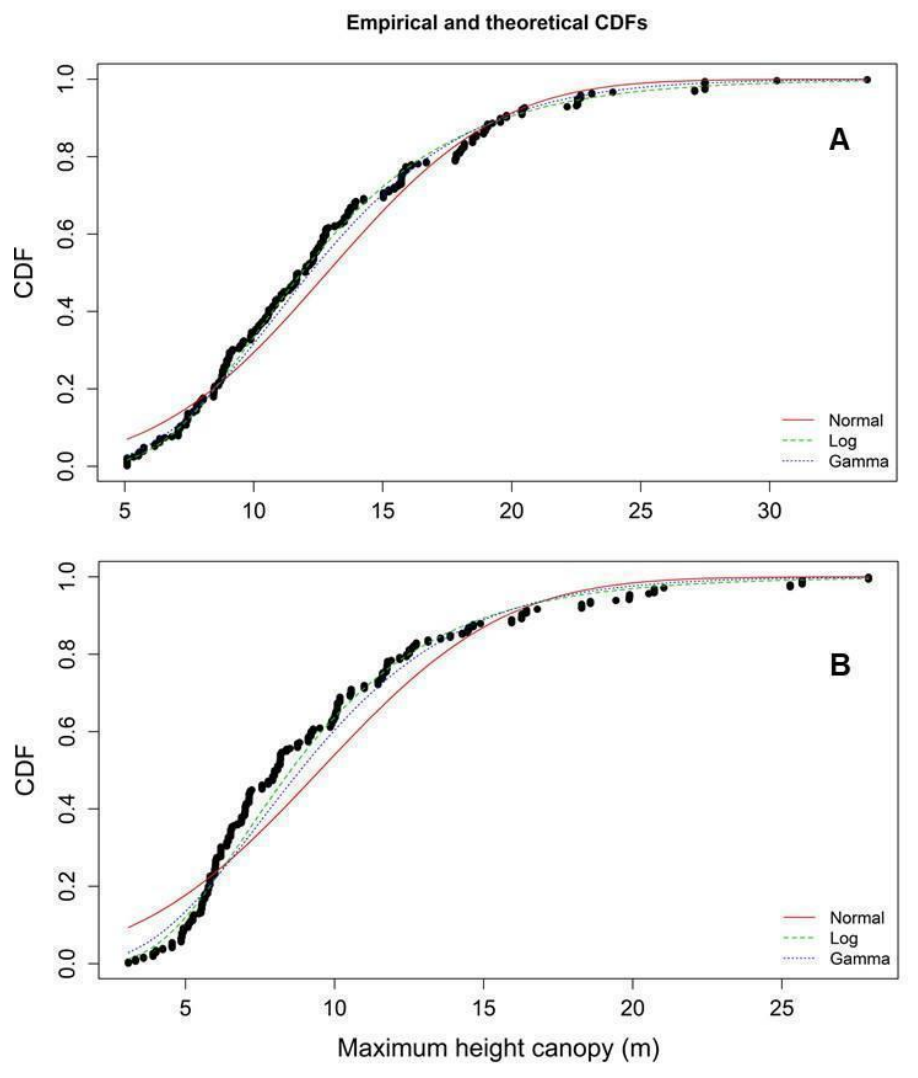

2 Figure S1. Graphical comparison of multiple fitted distributions of MCH in (A)

3 Cantareira and (B) Conduru study regions.

\section{$4 \quad$ 2.5.2. Younger - old growth $\mathrm{MCH}$ ratio}

To better understand spatial patterns related to positive and negative

6 edge effects, we performed a paired comparison between $\mathrm{MCH}$ of younger and

7 older forests. We used the edge distance gradient in intervals of $5 \mathrm{~m}$ to compare

$8 \mathrm{MCH}$ from paired younger and older transects, i.e. the MCH ratio. The aim of

9 this MCH ratio calculation was observed the difference between younger and

10 older forest along the gradient of edge distance and to identify if the spatial

11 pattern is uniform between the virtual transect pairs and along the same

12 transect pair. 


\section{Results}

As we expected from our hypothesis, edge effect was different to younger and older forests in both study regions, since the best explanatory model of MCH was the model with interaction between edge distance and successional stage (Table 1). The MCH ratio highlights that younger and old growth forest have contrasting edge effects (Figure 2A; $3 \mathrm{~A}$ ): this ratio is higher than one in areas near the edges (higher biomass in younger than in older forests), and then tended progressively to be lower than one in areas far from the edges.

The highest values of MCH were observed far from the edge in older forests and near to the edge in younger forests (Figure 2B and 3B). In the Cantareira region, $\mathrm{MCH}$ of older forest was mostly constant as edge distance increased. Contrary, the inverted edge effect (or positive edge effect) in the younger forest was pronounced (Figure 2B). In the Conduru region, we found a strong negative edge effect in older forest, i.e. the higher the proximity to the forest edge the smaller is the $\mathrm{MCH}$, as well as an inverted edge effect for younger forests, however less evident than the one observed for Cantareira (Figure 3B). Although the $\mathrm{MCH}$ is quite similar between younger and older forests in the first meters of the edge distance, the difference is more visible in the next meters where the $\mathrm{MCH}$ decrease in younger forests and increase in older forests. 


\section{Table 1 - Best supported models}

2 Best supported models to explain variation in the Maximum Canopy Height $3 \quad(\mathrm{MCH})$ in both study regions (Cantareira and Conduru). Explanatory variables 4 are edge distance and successional stage. The pair of younger and older forests 5 virtual sample transect was considered as a fixed effect in all models. Each 6 model is described by the degrees of freedom (df), $\triangle \mathrm{AICc}$ and weight. The tilde $7 \quad(\sim)$ means the function and the asterisk $\left(^{*}\right)$ the interaction. The virtual sample 8 transect was considered as a fixed effect in all models.

\begin{tabular}{|c|c|c|c|c|}
\hline Models & AICc & dAICc & df & weight \\
\hline \multicolumn{5}{|c|}{ Cantareira } \\
\hline $\mathrm{MCH} \sim$ edge distance ${ }^{*}$ successional stage & 336.8 & 0 & 6 & 0.9833 \\
\hline $\mathrm{MCH} \sim$ edge distance + successional stage & 346.3 & 9.5 & 5 & 0.0086 \\
\hline $\mathrm{MCH} \sim$ successional stage & 346.4 & 9.6 & 4 & 0.0080 \\
\hline null & 368.6 & 31.8 & 3 & $<0.001$ \\
\hline $\mathrm{MCH} \sim$ edge distance & 373.7 & 37 & 4 & $<0.001$ \\
\hline \multicolumn{5}{|c|}{ Conduru } \\
\hline $\mathrm{MCH} \sim$ edge distance * successional stage & 318.7 & 0 & 6 & 0.971 \\
\hline $\mathrm{MCH} \sim$ successional stage & 325.7 & 7 & 4 & 0.029 \\
\hline $\mathrm{MCH} \sim$ edge distance + successional stage & 340.3 & 21.6 & 5 & $<0.001$ \\
\hline null & 426.2 & 107.5 & 3 & $<0.001$ \\
\hline MCH edge distance & 444.0 & 125.3 & 4 & $<0.001$ \\
\hline
\end{tabular}



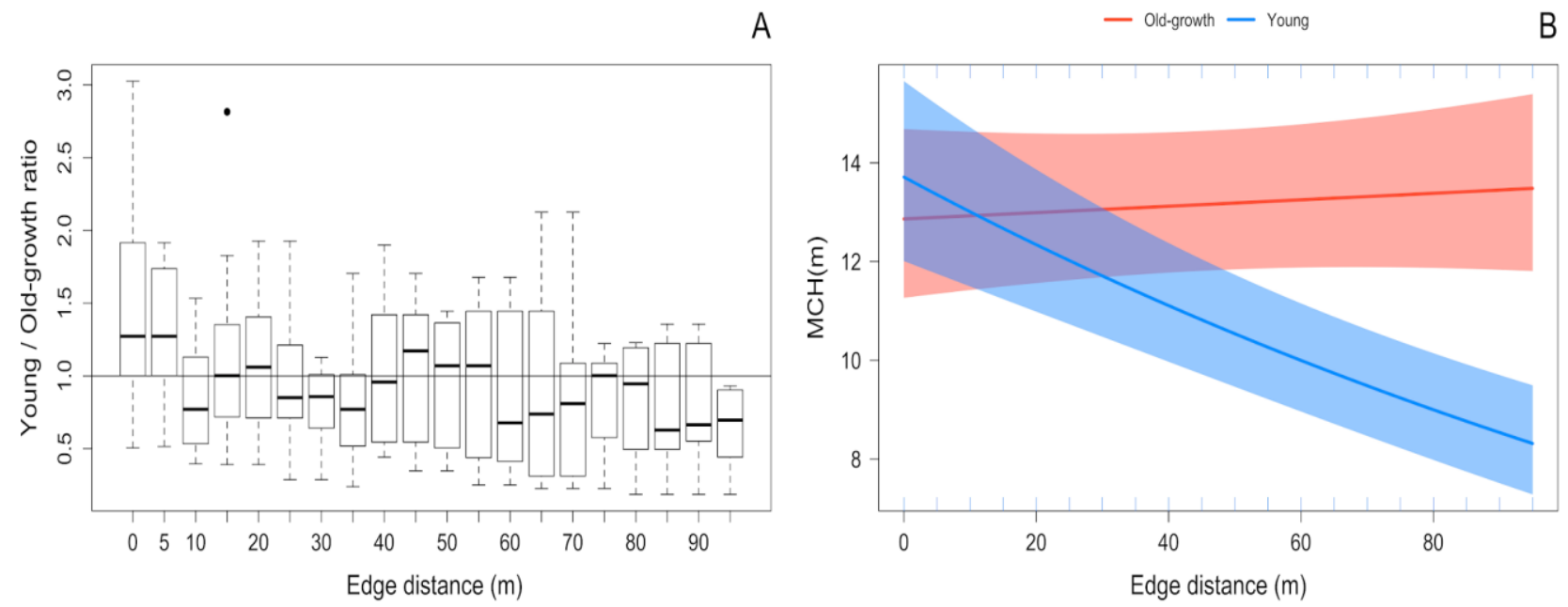

2 Figure 2. Relationship between (Maximum Height Canopy) MCH and edge 3 distance in Cantareira. A) Boxplot of MCH height ratio between younger and 4 older forests with a paired design. The line represents where these difference 5 does not exist. B) Relationship between MCH and edge distance in younger and 6 older forest separately (without considering a paired design).
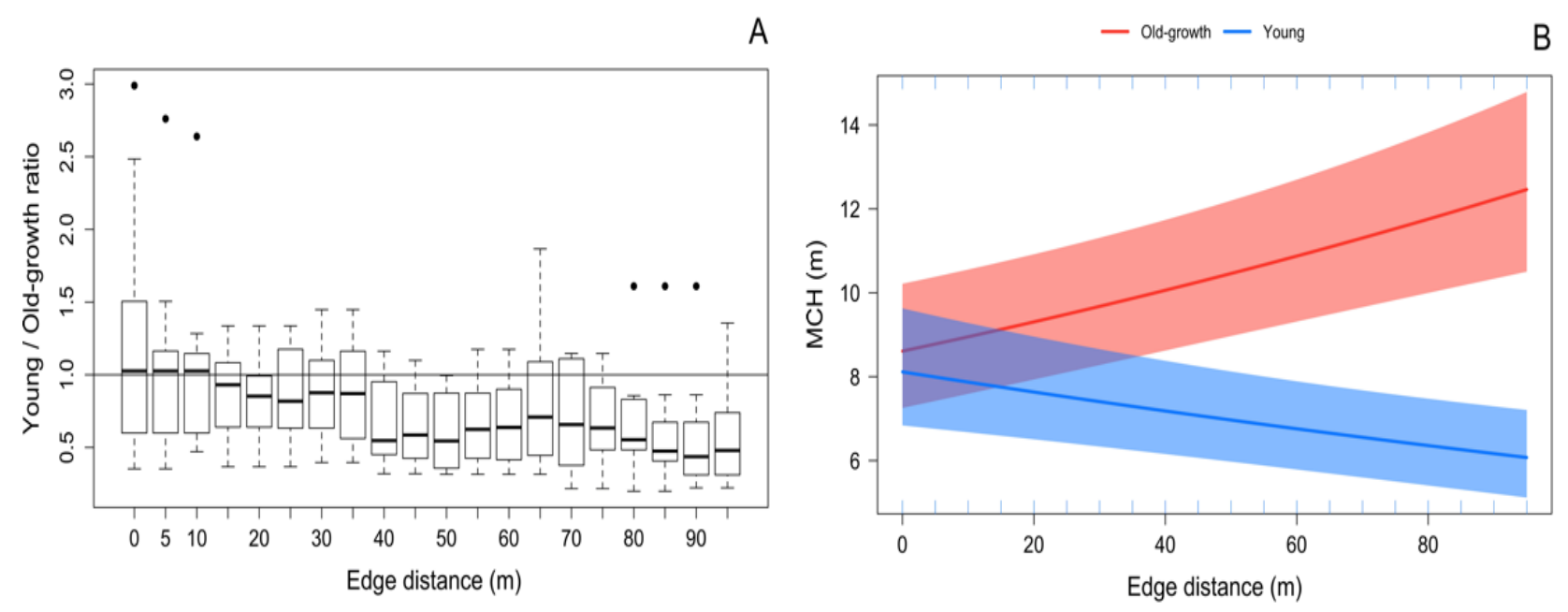

8 Figure 3. Relationship between (Maximum Height Canopy) MCH and edge

9 distance in Conduru. A) Boxplot of MCH height ratio between younger and older forests with a paired design. The line represents where these difference does not exist. B) Relationship between $\mathrm{MCH}$ and edge distance in younger and older forest separately (without considering a paired design).

The MCH ratio from each virtual transect showed high spatial heterogeneity in Cantareira (Figure S2) and in Conduru (Figure S3), mainly in an intermediary edge distance (40-80 m). Some pairs of transects showed MCH 
1 ratio lower than one along all the edge distance range (Figure S2A; S3A). In

2 contrast, we also found transects with $\mathrm{MCH}$ ratio higher than one all along the

3 edge distance range (Figure S2H; S3I). Nonetheless, $\mathrm{MCH}$ ratio near to the edge

4 was usually higher than one, while being lower than one far from the edges,

5 which means that the inverted edge effect in the younger forest is observed in

6 most pairs of transects (Table S1).

7 Table S1 - MCH Younger-Old growth forest slope, slope p value and r2

8 MCH Younger-Old growth forest slope, slope $p$ values and $\mathrm{r} 2$ in relation de the 9 edge distance in in Cantareira and Conduru.

\begin{tabular}{|c|c|c|c|}
\hline \multicolumn{5}{|c|}{ Cantareira } \\
\hline Pair & Slope & Slope $\boldsymbol{p}$ value & $\mathbf{r}^{\mathbf{2}}$ \\
\hline A & -0.005 & 0.003 & 0.394 \\
\hline B & 0.003 & 0.179 & 0.098 \\
\hline C & -0.004 & 0.103 & 0.140 \\
\hline D & -0.007 & 0.012 & 0.3029 \\
\hline E & -0.004 & 0.353 & 0.0481 \\
\hline F & -0.006 & 0.132 & 0.4591 \\
\hline G & -0.017 & 0.002 & 0.644 \\
\hline H & -0.014 & 0.009 & 0.320 \\
\hline I & -0.003 & 0.173 & 0.101 \\
\hline J & 0.007 & 0.015 & 0.289 \\
\hline \multicolumn{5}{|c|}{ Conduru } \\
\hline Pair & slope & Slope $\boldsymbol{p}$ value & $\mathbf{r}^{2}$ \\
\hline A & -0.003 & 0.039 & 0.215 \\
\hline B & -0.007 & 0.000 & 0.566 \\
\hline C & 0.001 & 0.604 & 0.015 \\
\hline D & -0.003 & 0.001 & 0.494 \\
\hline E & 0.000 & 0.593 & 0.016 \\
\hline F & -0.009 & 0.000 & 0.527 \\
\hline G & -0.002 & 0.026 & 0.246 \\
\hline H & 0.001 & 0.822 & 0.003 \\
\hline I & -0.021 & 0.002 & 0.634 \\
\hline J & -0.009 & 0.004 & 0.613 \\
\hline
\end{tabular}



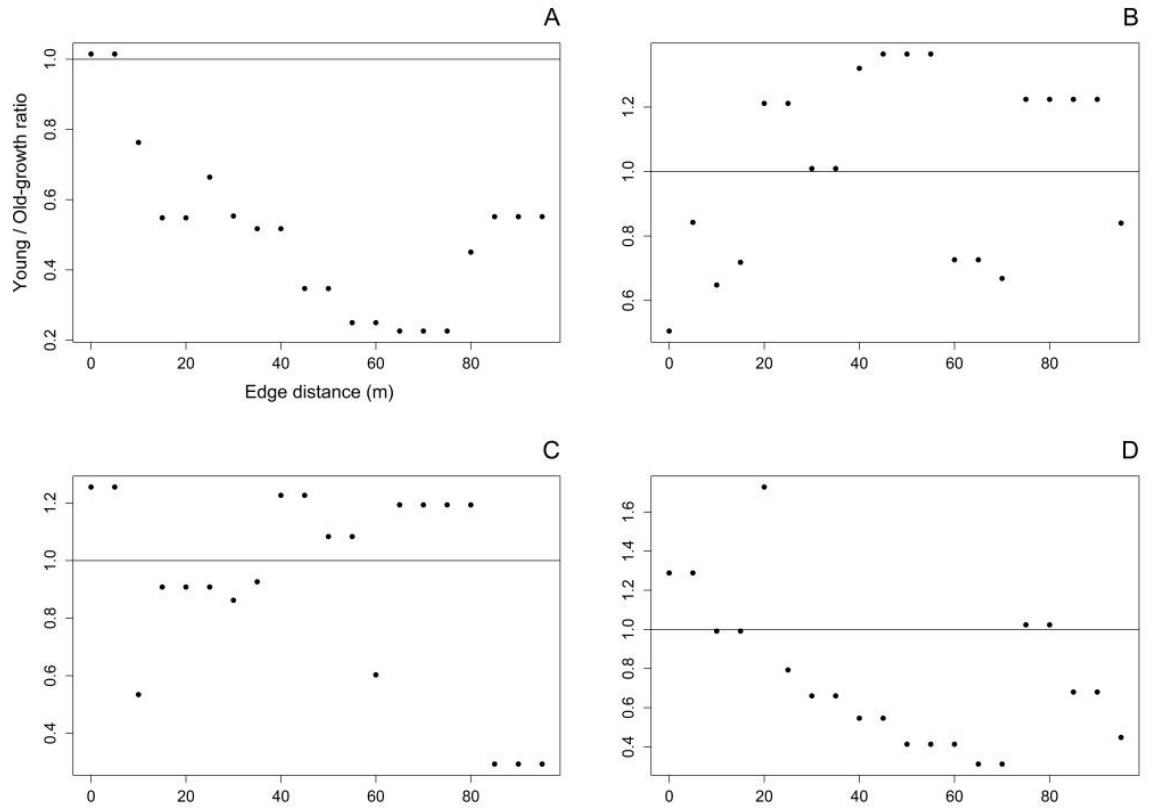

2
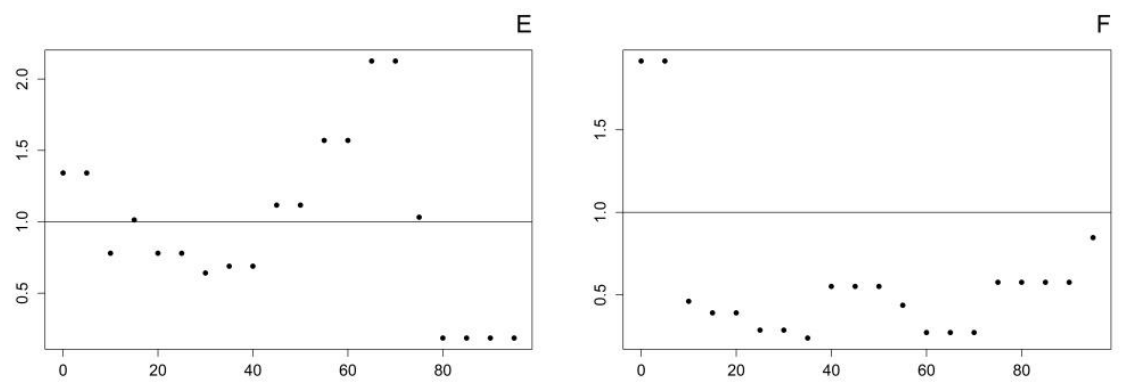

3
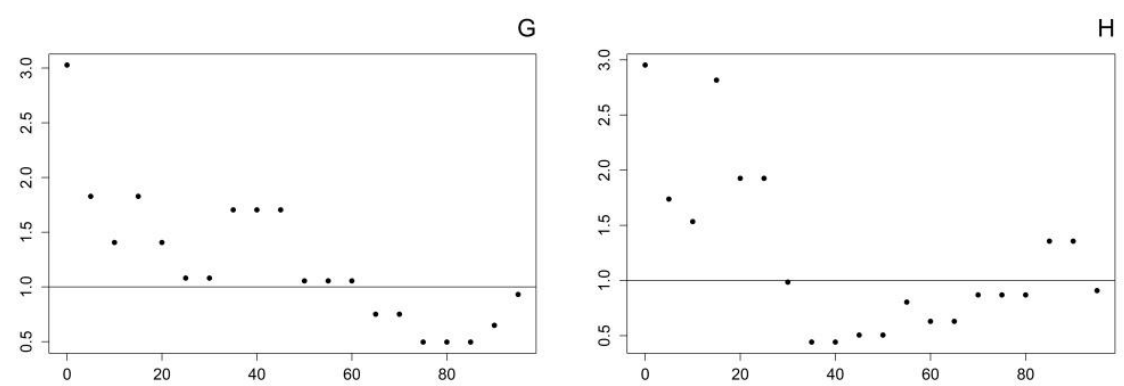

4
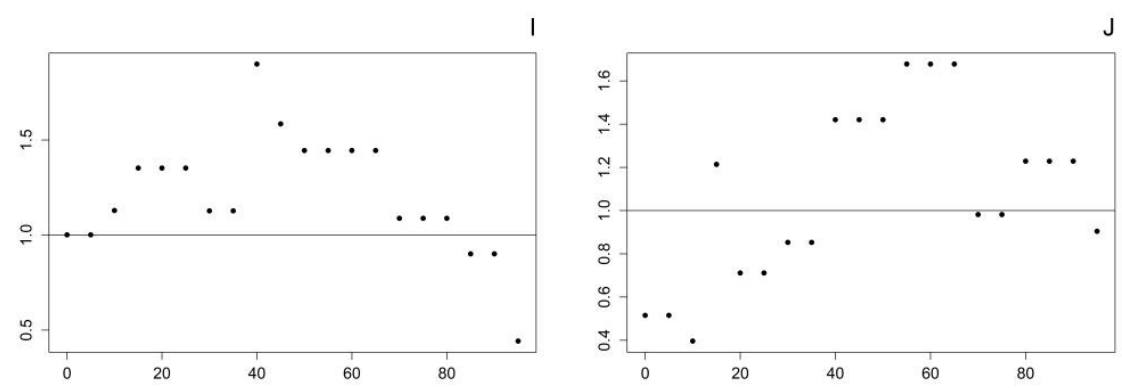

5

6 Figure S2. Representation of Maximum Height Canopy (MCH) height ratio

7 between younger and older forests for each virtual sampled transect in

8 Cantareira. The line represents where these difference does not exist. 

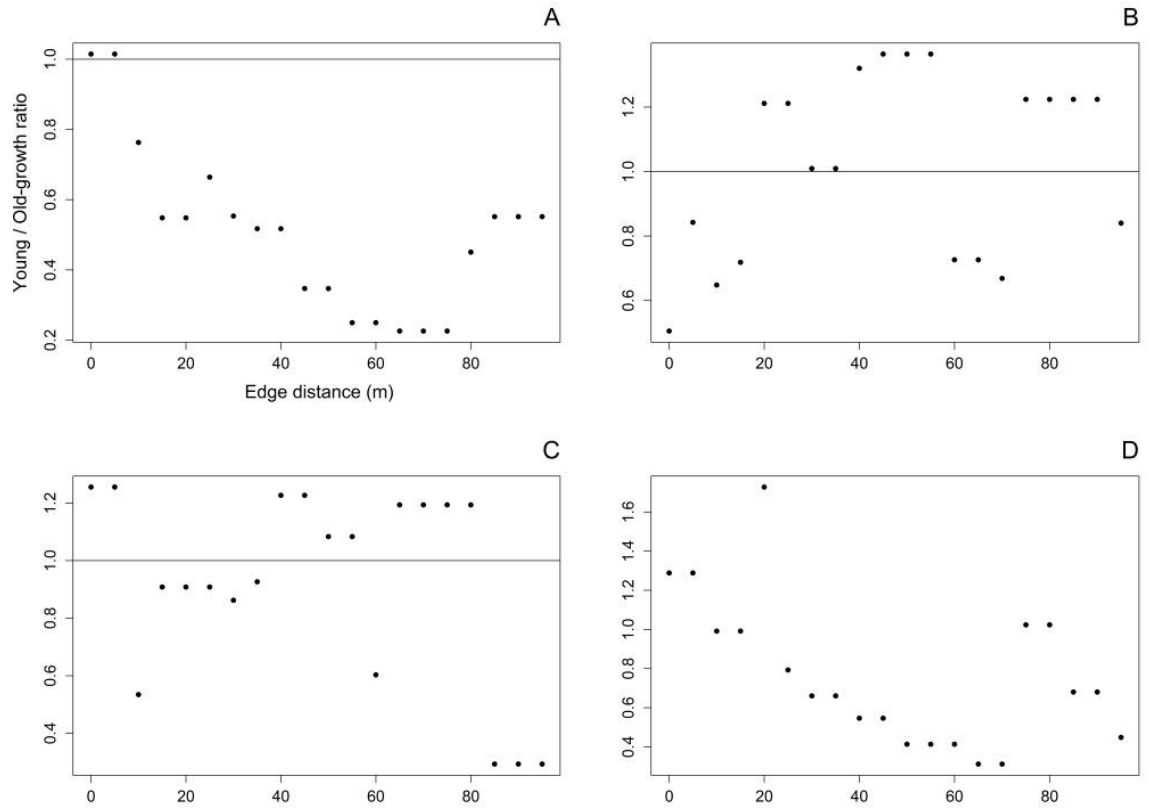

2
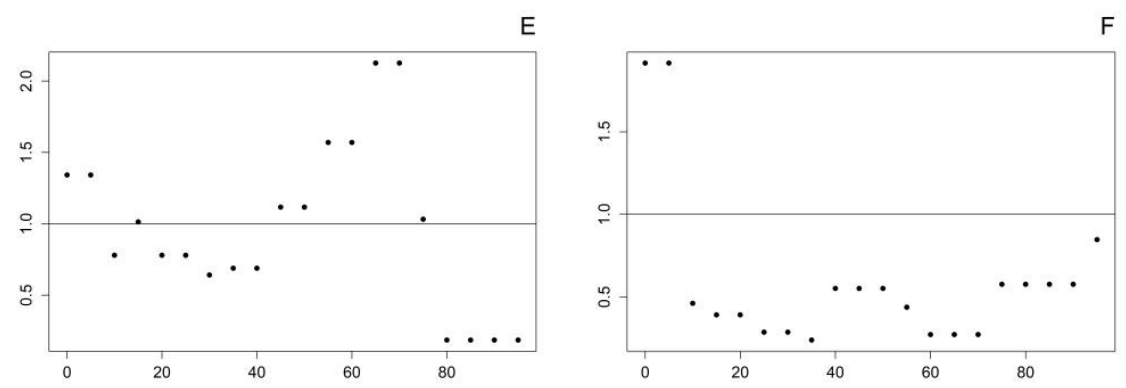

3
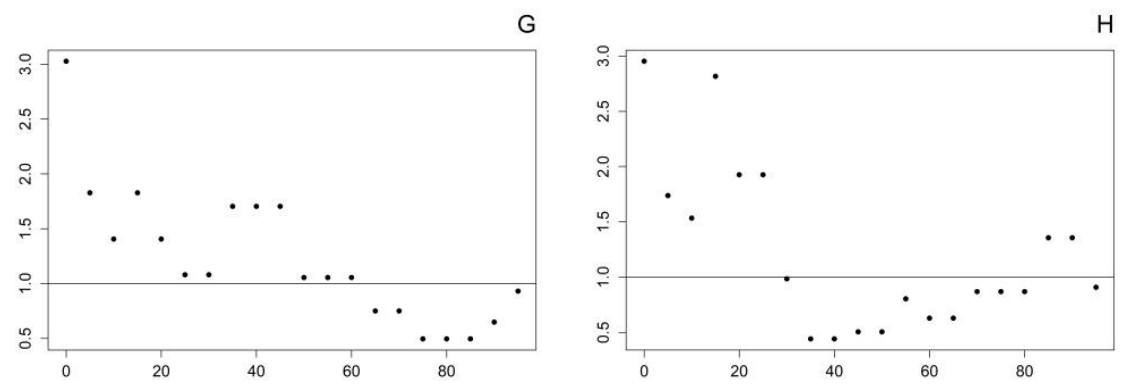

4
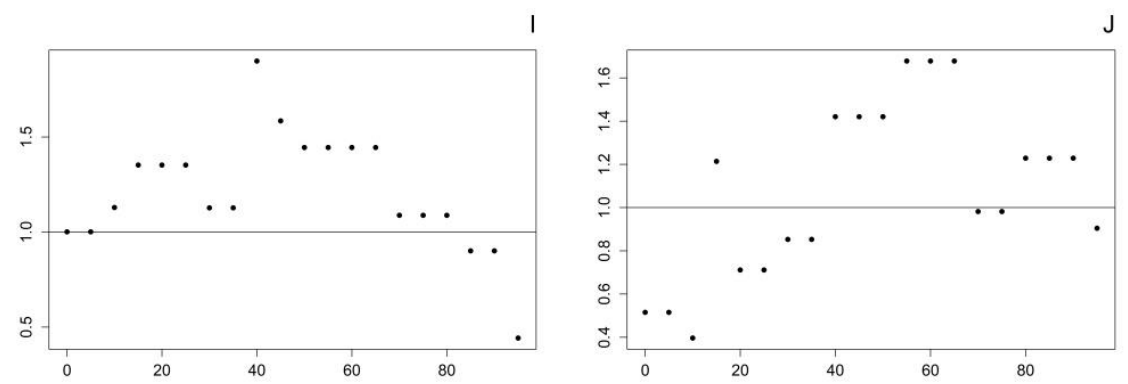

5

6 Figure S3. Representation of (Maximum Height Canopy) MCH height ratio

7 between younger and older forests for each virtual sampled transect in

8 Conduru. The line represents where these difference does not exist. 


\section{Discussion}

We found contrasting spatial patterns of edge effects on vegetation structure from fragmented and degraded Atlantic tropical forests. Edge effect influenced both younger and older forests, although the increase in distance from the forest edge resulted in positive and negative consequences to canopy height in younger and older forests, respectively. These results indicate that changes in canopy height due to edge effect depend on the interaction between edge distance and successional stage. Consequently, forest age should affect large-scale spatial patterns of forest biomass and carbon stock. Additionally, the inverted edge effect pattern was found in different landscape contexts, with distinct level of forest cover and abiotic and biotic characteristics, which suggest this pattern should be quite common in secondary tropical landscapes.

In light of the global tendency of increasing forest fragmentation in different forest ecosystems, quantitative characterization of the effects of fragmentation on forest growth and its interaction with climate is essential for forest carbon balance and climate projections (Reinmann and Hutyra, 2017). The younger and older forest distinction approach in carbon stocks estimations and restoration strategies are essential to consider, since the ecological mechanisms are completely different. The inverted edge effect pattern was revealed here with a systematic and robust approach in distinct 
1 landscapes contexts. It cannot be any more ignored in future estimation and

2 mapping of above-ground biomass (carbon stock).

7 to model based on the limited data available (Norden et al., 2015).

8 Furthermore, secondary tropical forests have rapid rates of carbon

Our findings contribute to the understanding about the landscapescale drivers of forest regrowth and carbon stock accumulation, which is very important in planning forest regeneration projects. This type of information is poorly understood in secondary tropical forests and difficult sequestration, with potentially large consequences for the global carbon cycle (Pan et al., 2011). Forests with more than 30 years of regeneration accumulate $50 \%$ more carbon than a forest with less than 30 years old (Romitelli et al., in prep). Most of above-ground biomass and carbon stock approaches were not designed to capture the effects of edges and fragmentation on forest growth and biomass and do not capture this important determinant of forest carbon balance and its sensitivity to climate. Given the continued forest fragmentation, edge effects will play an important role in constraining estimates of the terrestrial carbon sink and its feedback with climate (Reinmann and Hutyra, 2017). We show here that this carbon accumulation process is spatially heterogeneous within the edge distance gradient. So the arrangement of the remaining forest in which best improves the carbon stock accumulation should be considered in landscape restoration. 
1 Even though the actual younger forest proportion of Atlantic forest is

2 relatively low (6,78\%; MapBiomas Project, 2019), some Payment for

3 Ecosystem Services programs and other initiatives to restore forest cover of

$4 \quad$ Atlantic forest aim to recover more than 15 million hectares until 2050

5 (Pacto, 2019). This value represents almost 50\% of current forest cover of

6 Atlantic forest with less than 30 years old which increased $70 \%$ of the

7 proportion of younger forests. Further, in the face of optimizing restoration

8 efforts, in this restoration projects of Atlantic forest for example, our results

9 suggest that forest restoration projects around existing forest olders can

10 both reduce edge effects in older patches and favor biomass regrowth in

11 regenerating or restored forests, being thus doubly beneficial to increase

12 carbon stock in human-dominated landscapes.

\section{Acknowledgments}

We thank all landowners for giving permission to conduct fieldwork on their lands and for the outstanding support. This study was developed within the "Interface Project", supported by São Paulo Research Foundation (FAPESP, 2013/23457-6). I.R. was supported by a doctorate's fellowship from the Brazilian Ministry of Education (CAPES-DS, 2015-2019). 


\section{References}

2 Asner, G. P., Mascaro, J. 2014. Mapping tropical forest carbon: Calibrating

3 plot estimates to a simple LiDAR metric. Remote Sensing of Environment, $4 \quad 140$, pp. 614-624.

5 Becknell, J.M., Keller, M., Piotto, D., Longo, M., dos-Santos, M.N., Scaranello, 6 M.A., Cavalcante, R.B.O., Porder, S. 2018. Landscape-scale lidar analysis of 7 aboveground biomass distribution in secondary Brazilian Atlantic Forest. 8 Biotropica, 50 (3), 520-530.

9 Briant, G., Gond, V., Laurance, S. G. W. 2010. Habitat fragmentation and the 10 desiccation of forest canopies: a case study from eastern Amazonia. 11 Biological Conservation, 143, pp. 2763-2769.

Burnham, K.P., Anderson, D.R. 2002. Model selection and multimodel inference. A practical information-theoretic approach. Springer, New York.

Chaplin-Kramer, R., Ramler, I., Sharp, R., Haddad, N.M., Gerber, J.S., West, P.C., Mandle, L., Engstrom, P., Baccini, A., Sim, S., Mueller, C., King, H. 2015. Degradation in carbon stocks near tropical forest edges. Nature Communication, 6, 10158.

Costa, K.M. 2015. 0 estoque de carbono na vegetação e no solo em

Crouzeilles, R., Ferreira, M., Chazdon, R., Lindenmayer, D., Sansevero, JLB.B., Monteiro, L., Iribarrem, A., Agnieszka, A., Strassburg, B. 2017. Ecological restoration success is higher for natural regeneration than for active restoration in tropical forests. Science Advances. 3. e1701345.

Curran, L.M., Caniago, I., Paoli, G.D., Astianti, D., Kusneti, M., Leighton, M.,

Didham, R.K., Lawton, J.H. 1999. Edge structure determines the magnitude of changes in microclimate and vegetation structure in tropical forest fragments. Biotropica, 31, pp.17-30.

Food and Agriculture Organization of the United Nations. Global Forest 
1 Haddad, N.M., Brudvig, L.A., Clobert, J., Davies, K.F., Gonzalez, A, Holt, R.D.,

2 Lovejoy, T.E., Sexton, J.O., Austin, M.P., Collins, C.D., Cook, W.M., Damschen,

3 E.I., Ewers, R.M., Foster, B.L., Jenkins, C.N., King, A.J., Laurance, W.F., Levey,

4 D.J., Margules, C.R., Melbourne, B.A., Nichols, A.O., Orrock, J.L., Song, D,

5 Townshend, J.R. 2015. Habitat fragmentation and its lasting impact on

6 Earth's ecosystems. Science Advances, 1(2), e1500052.

7 Joly, C.A., Rodrigues, R.R., Metzger, J.P., Haddad, C.F.B., Verdade, L.M.,

8 Oliveira, M.C., Bolzani, V.S. 2010. Biodiversity Conservation Research,

$9 \quad$ Training, and Policy in São Paulo. Science 328 1358-1359.

Joly, C.A., Metzger, J.P., Tabarelli, M. 2014. Experiences from the Brazilian Atlantic Forest: ecological findings and conservation initiatives. New Phytol. 204459-73.

Laurance, W. F. 1997. Biomass collapse in Amazonian forest fragments. Science, 278, pp. 1117-1118.

Laurance, W.F., Camargo, J.L.C., Luizão, R.C.C., Laurance, S.G., Pimm, S.L., Bruna, E.M., Stouffer, P.C., Williamson, G.B., Benítez-Malvido, J., Vasconcelos, H.L., Van Houtan, K.S., Zartman, S.E., Boyle, S.A., Didham, R.K., Andrade, A., Lovejoy, T.E. 2011. The fate of Amazonian forest fragments: A 32-year investigation. Biol. Conserv. 144, 56-67.

Lefsky,M.A. , Cohen, W.B. , Harding, D.J., Parker, G.G., Acker, S.A, Gower, S.T. 2002. Lidar remote sensing of above-ground biomass in three biomes. Glob. Ecol. Biogeogr., 11, pp. 393-399.

Leitold, V., Keller, M., Morton, D.C., Cook, B.D., Shimabukuro, Y.E. 2015. Airborne lidar-based estimates of tropical forest structure in complex

Matlack, G.R. 1993. Microenvironment variation within and among terrain: opportunities and trade-offs for REDD. Carbon Balance Management, 10 (3).

MapBiomas Project. Collection 3.1 of Land use and mapping annual series, accessed on 15/02/2019 by the link: http://mapbiomas.org. deciduous forest edge sites in the eastern United States. Biology Conservation, 66, pp. 185-94. 
1 Melito, M., Metzger, J.P., de Oliveira, A.A. 2018. Landscape-level effects on 2 aboveground biomass of tropical forests: a conceptual framework. Glob. 3 Change Biol. 24: 597-607.

4 Norden, N., Angarita, H.A., Bongers, F., Martinez-Ramos, M., Granzon de la 5 Cerda, I., van Breugel, M.,Lebrija-Trejos, J., Meave, J.A., Vandermeer, G. B., 6 Williamson, B., Finegan, B., Mesquita, R, Chazdon, R.L. 2015. Successional 7 dynamics in Neotropical forests are as uncertain as they are predictable. 8 Proceedings of the National Academy of Sciences, 112, pp. 8013-8018.

9 Pacto pela restauração da mata atlântica : referencial dos conceitos e ações

Pan, Y., Birdsey, R.A., Fang, J., Houghton, R., Kauppi, P.E., Kurz, W.A., Phillips, de restauração florestal [organização e edição de texto: Ricardo Ribeiro Rodrigues, Pedro Henrique Santin Brancalion, Ingo Isernhagen]. - São Paulo : LERF/ESALQ : Instituto BioAtlântica, 2009. O.L., Shvidenko, A., Lewis, S.L., Canadell, J.G., Ciais, P., Jackson, R.B., Pacala, S.W., McGuire, A.D., Piao, S., Rautiainen, A., Sitch, S., Hayes, D. 2011. A large and persistent carbon sink in the world's forests. Science 333, 988-993.

Peters, H. A. 2001. Clidemia hirta invasion at the Pasoh forest reserve: an unexpected plant invasion in an undisturbed tropical forest. Biotropica, 33, pp. 60-68.

Pütz, S., Groeneveld, J., Alves, L.F., Metzger, J.P., Huth, A. 2011. Fragmentation drives tropical forest fragments to early successional states: a modelling study for Brazilian Atlantic forests. Ecol. Model. 222, 1986-1997.

R Development Core Team. 2019. R: A language and environment for statistical computing. R Foundation for Statistical Computing, Vienna, Austria. ISBN 3-900051-07-0, Available in: URL http://www.R-project.org.

Reinmann, A.B., Hutyra, L.B. 2017. Edge effects enhance carbon uptake and its vulnerability to climate change in temperate broadleaf forests. PNAS 114 (1), pp. 107-112.

Remy, E., Wuyts, K., Boeckx, P., Ginzburg, S., Gundersen, P., Demey, A., den Bulcke, J.V., Van Acker, J., Verheyen, K. 2016 .Strong gradients in nitrogen and carbon stocks at temperate forest edges. Forest Ecology Management, 376, pp. 45-58. 
1 Rezende, C.L., Scarano, F.R., Assadd, E.D., Joly, C.A., Metzger, J.P., Strassburgg,

2 B.B.N., Tabarelli, M., Fonseca, G.A., Mittermeier, R.A. 2018. From hotspot to

3 hopespot: An opportunity for the Brazilian Atlantic Forest. Perspectives in

4 Ecology and Conservation, 16 (4), pp. 208-214.

5 Ribeiro, M.C., Metzger, J.P., Martensen, A.C., Ponzoni, F.J., Hirota, M.M., 2009.

6 The Brazilian Atlantic Forest: How much is left and how is the remaining

7 forest distributed? Implications for conservation. Biol. Conserv. 142, 1141-

81153.

9 Ries, L., Fletcher Jr, R.J., Battin, J., Sisk, T.D. 2004. Ecological responses to

10 habitat edges: mechanisms, models and variability explained. Annual

11 Review Ecology Systematic, 35, pp. 491-522.

Rodrigues, R.R., Joly, C.A., Brito, M.C.W., Paese, A., Metzger, J.P., Cassati, L., Nalon, M.A., Menezes, N., Ivanauskas, N.M., Bolzani, V., Bononi, V.L.R. 2008. Diretrizes para conservação e restauração da biodiversidade no Estado de São Paulo. Governo do Estado de São Paulo, São Paulo.

Romitelli, I., Barbosa, J.M., Polisel, R.T., Keller, M., Metzger, J.P. (1) Inverted edge effect pattern on carbon stocks in secondary tropical forests (chapter $1)$.

Romitelli, I., Barbosa, J.M., Metzger, J.P. (2) Landscape effects overtake abiotic and age influences on forest biomass in tropical fragmented landscapes (chapter 2).

Romitelli, I., D'Albertas, F., Costa, K., Vieira, S.A., Metzger, J.P. Tropical forests in human-dominated landscapes present low biomass stocks and high spatial variability (in prep.).

Schmidt, M., Jochheim, H., Kersebaum, K.C., Gunnar, L., Nendela, C. 2017. Gradients of microclimate, carbon and nitrogen in transition zones of fragmented landscapes: a review. Agricultural and Forest Meteorology, 232, pp. 659-71.

Sizer, N., Tanner, E.V.J. 1999. Responses of woody plant seedlings to edge formation in a lowland tropical rainforest, Amazonia. Biological Conservation, 91, pp. 135-142. 
1 Smith, I.A., Hutyra, L.R., Reinmann, A.B., Marrs, J.K., Thompson, J.R. 2018.

2 Piecing together the fragments: elucidating edge effects on forest carbon

3 dynamics. Frontiers in Ecology Environmental, 16(4), pp. 213-221.

4 Wasser, L., Day,R., Chasmer, L.,Taylor,A. 2013. Influence of Vegetation

5 Structure on Lidar-derived Canopy Height and Fractional Cover in Forested

$6 \quad$ Riparian Buffers During Leaf-Off and Leaf-On Conditions. PLoS One 8(1).

7 Weathers, K.C., Cadenasso, M.L., Pickett, S.T.A. 2001. Forest edges as nutrient

8 and pollutant concentrators: potential synergisms between fragmentation,

9 forest canopies, and the atmosphere. Conservation Biology, 15, pp. 15061014.

11 Whately, M., Cunha, P. 2006. Um olhar sobre o maior manancial de água da 12 Região Metropolitana de São Paulo. In. Instituto Socioambiental São Paulo. 


\section{Conclusão geral}

As florestas tropicais em paisagens antropizadas estudadas aqui apresentaram um valor relativamente baixo de estoque de carbono relativo a outras florestas secundárias tropicais (Romitelli et al., in prep) tanto em áreas próximas, quanto mais distantes da borda. Os resultados do capítulo 1 permitiram indicar, pela primeira vez na literatura de florestas tropicais, que há mais estoque de carbono próximo a borda do que no interior em

florestas jovens localizadas em paisagens fragmentadas. Esse inesperado padrão invertido de biomassa em bordas florestais contradiz o padrão usualmente reportado em inúmeras publicações. Esse padrão invertido pode estar ligado a um efeito positivo das condições microclimáticas nas bordas, que podem estimular a propagação e o crescimento de árvores. 0 estoque de carbono das paisagens estudadas foi diretamente afetado pela distância à borda, quantidade de floresta remanescente na paisagem e composição florística. Nesse, sentido a configuração da paisagem desempenha um importante papel na modulação de estoque de carbono, algo muito pouco descrito na literatura até o momento.

Após a identificação do padrão invertido de efeito de borda e a importância do contexto da paisagem na regulação do estoque de carbono de florestas secundárias, no capítulo 2 , testamos se esse padrão se repete em diferentes paisagens, que diferem em cobertura florestal e grau de perturbação. Além da paisagem da região da Cantareira, consideramos 
1 outras três paisagens no Conduru. Concluímos que os fatores da paisagem

2 (cobertura florestal e distância da borda) possuem maior importância

3 relativa para a estrutura da vegetação (altura do dossel), do que os fatores

4 de relevo e idade, estes dois últimos sendo já bastante explorados e

5 conhecidos. Esse padrão foi verificado para florestas jovens e maduras e

6 para as duas regiões, mesmo sendo elas com contextos bastante distintos.

7 Embora os fatores da paisagem tenham se mostrado bastante importantes

8 para a regeneração da estrutura da vegetação e acúmulo de biomassa, os

9 modelos de estimativa de biomassa em larga escala (por exemplo: Baccini et

10 al., 2012; Mitchard et al., 2014; Urbazaev et al., 2018) não utilizam esses

11 fatores como variáveis preditoras. Dessa forma, este capítulo aponta para a

12 necessidade de considerar tais fatores para melhores estimativas de biomassa em florestas secundárias tropicais de paisagens antrópicas.

Por fim, no terceiro e último capítulo, conseguimos avaliar de forma sistemática e pareada diferenças no efeito de borda sobre o dossel de florestas jovens e maduras. Como esperado, o padrão usual de efeito de borda negativo para florestas maduras foi observado para as duas regiões, embora de forma mais intensa no Conduru, onde a proporção de vegetação nativa é muito superior e possivelmente os processos ecológicos de florestas maduras ainda estão mantidos próximo aos $100 \mathrm{~m}$ da borda. Por outro lado, observamos um efeito consistente de borda invertido para as florestas mais 
1 padrão deve ocorrer em outras paisagens tropicais degradadas e

2 fragmentadas, onde a regeneração está ocorrendo.

De forma conjunta, os três capítulos indicam que em florestas secundárias tropicais em paisagens antropizadas, o estoque de carbono é muito abaixo do que em outras florestas tropicais menos perturbadas. Além disso, existe uma alta heterogeneidade espacial, guiada por fatores de paisagem e locais, como por exemplo perturbações antrópicas. Tendo em vista as implicações globais da intensa fragmentação florestal para os processos ecossistêmicos, trabalhos como esse que quantificam os efeitos da fragmentação e do efeito de borda em florestas jovens e maduras, são essenciais para projeções climáticas e de estoque de carbono (Reinmann \& Hutyra, 2017).

Os dados e análises apresentados na tese fornecem importantes informações de suporte para o manejo de carbono florestal de vegetação nativa em nível de paisagem. Por exemplo, vimos que a configuração dos fragmentos florestais pode influir em maiores estoques de carbono, e desta forma, sugerimos incrementar a cobertura florestal ao redor de florestas remanescentes por meio de projetos de restauração. Com esse tipo de ação seria possível amenizar o efeito de borda negativo para florestas maduras e ao mesmo tempo promover a regeneração em florestas jovens que apresentaram maiores valores de estoque de carbono próximo à borda. 
$1 \quad$ Nossos dados indicam que a maior efetividade de programas de

2 mitigação de mudanças climáticas, como o REDD+ (Redução das Emissões

3 por Desmatamento e Degradação Florestal), depende de um bom

4 planejamento de ações a nível de paisagem, considerando os efeitos

5 distintos de borda em florestas jovens e mais maduras. Neste sentido, é

6 importante ressaltar a importância de evitar a perda de áreas de florestas

7 nativas mais antigas, e estimular a regeneração florestal ao longo das bordas

8 de florestas remanescentes. Esse simples planejamento espacial permitirá

9 não apenas otimizar os ganhos de carbono por meio da restauração, mas

10 também minimizar as perdas que ocorrem por meio de efeito de borda em

11 florestas remanescentes. 
1 Referências bibliográficas da introdução e conclusão geral

2 Achard, F., Eva, H.D., Stibig, H.J., Mayaux, P., Gallego, J., Richards, T., Malingreau, J.P. 2002. Determination of deforestation rates of the world's humid tropical forests. Science 297, 999-1002.

Asner, G. P., Mascaro, J. 2014. Mapping tropical forest carbon: Calibrating plot estimates to a simple LiDAR metric. Remote Sensing of Environment, 140, pp. 614-624.

Baccini, A., Goetz, S. J., Walker, W. S., Laporte, N. T., Sun, M., Sulla-Menashe, D., Hackler, J., Beck, P.S.A., Dubayah, R., Friedl, M.A., Samanta, S., Houghton, R.A. 2012. Estimated carbon dioxide emissions from tropical deforestation improved by carbon-density maps. Nature Climate Change, 2, 182.

Becknell, J.M., Keller, M., Piotto, D., Longo, M., dos-Santos, M.N., Scaranello, M.A., Cavalcante, R.B.O., Porder, S. 2018. Landscape-scale lidar analysis of aboveground biomass distribution in secondary Brazilian Atlantic Forest. Biotropica, 50 (3), 520-530.

Brown, S., Lugo, A.E. 1990. Tropical secondary forests. J. Trop. Ecol. 6, 1-31.

Chaplin-Kramer, R., Ramler, I., Sharp, R., Haddad, N.M., Gerber, J.S., West, P.C., Mandle, L., Engstrom, P., Baccini, A., Sim, S., Mueller, C., King, H. 2015. Degradation in carbon stocks near tropical forest edges. Nature Communication, 6, 10158.

Falkowski P., Scholes, R.J., Boyle, E., ‡Canadell, J., Canfield, D., Elser, J., Gruber, N., Hibbard, K., Högberg, P., Linder, S., Mackenzie, F.T., Moore, B., Pedersen, T., Rosenthal, Y., ‡Seitzinger, S., Smetacek, V., Steffen, W. 2000. The Global Carbon Cycle: A Test of Our Knowledge of Earth as a System. Science, 290, pp. 291-296.

Food and Agriculture Organization of the United Nations. Global Forest Resources Assessment. 2017. FAO Forestry Paper.

Grace, J., San José, J., Meir, Miranda, H.S., Ruben, A.M. 2006. Productivity and carbon fluxes of tropical savannas. Journal of Biogeography, 33

Haddad, N.M., Brudvig, L.A., Clobert, J., Davies, K.F., Gonzalez, A, Holt, R.D., Lovejoy, T.E., Sexton, J.O., Austin, M.P., Collins, C.D., Cook, W.M., Damschen, E.I., Ewers, R.M., Foster, B.L., Jenkins, C.N., King, A.J., Laurance, W.F., Levey, D.J., Margules, C.R., Melbourne, B.A., Nichols, A.O., Orrock, J.L., Song, D, 
Townshend, J.R. 2015. Habitat fragmentation and its lasting impact on Earth's ecosystems. Science Advances, 1(2), e1500052.

IPCC. 2018. Contribution of Working Groups I, II and III to the Fourth Assessment Report of the Intergovernmental Panel on Climate Change. In Climate Change, Synthesis Report, Core Writing Team, Pachauri, R.K. and Reisinger, A. (eds), Geneva, Switzerland.

Joly, C.A., Metzger, J.P., Tabarelli, M. 2014. Experiences from the Brazilian Atlantic Forest: ecological findings and conservation initiatives. New Phytol. 204459-73.

Joly, C.A., Rodrigues, R.R., Metzger, J.P., Haddad, C.F.B., Verdade, L.M., Oliveira, M.C., Bolzani, V.S. 2010. Biodiversity Conservation Research, Training, and Policy in São Paulo. Science 328 1358-1359.

Laurance, W. F. 1997. Biomass collapse in Amazonian forest fragments. Science, 278, pp. 1117-1118.

Lefsky,M.A. , Cohen, W.B. , Harding, D.J., Parker, G.G., Acker, S.A, Gower, S.T. 2002. Lidar remote sensing of above-ground biomass in three biomes. Glob. Ecol. Biogeogr., 11, pp. 393-399.

Metzger, J. P. 2009. Conservation issues in the Brazilian Atlantic forest. Biol. Conserv. 142, 1138-1140.

Mitchard, E. T. A., Feldpausch, T. R., Brienen, R. J. W., Lopez-Gonzalez, G., Monteagudo, A., Baker, T. R., Lewis, S. L., Lloyd, J., Quesada, C. A., Gloor, M., ter Steege, H., Meir, P., Alvarez, E., Araujo-Murakami, A., Aragão, L. E. O. C., Arroyo, L., Aymard, G., Banki, O., Bonal, D., Brown, S., Brown, F. I., Cerón, C. E., Chama Moscoso, V., Chave, J., Comiskey, J. A., Cornejo, F., Corrales Medina, M., Da Costa, L., Costa, F. R. C., Di Fiore, A., Domingues, T. F., Erwin, T. L., Frederickson, T., Higuchi, N., Honorio Coronado, E. N., Killeen, T. J., Laurance, W. F., Levis, C., Magnusson, W. E., Marimon, B. S., Marimon Junior, B. H., Mendoza Polo, I., Mishra, P., Nascimento, M. T., Neill, D., Núñez Vargas, M. P., Palacios, W. A., Parada, A., Pardo Molina, G., Peña-Claros, M., Pitman, N., Peres, C. A., Poorter, L., Prieto, A., Ramirez-Angulo, H., Restrepo Correa, Z., Roopsind, A., Roucoux, K. H., Rudas, A., Salomão, R. P., Schietti, J., Silveira, M., de Souza, P. F., Steininger, M. K., Stropp, J., Terborgh, J., Thomas, R., Toledo, M., Torres-Lezama, A., van Andel, T. R., van der Heijden, G. M. F., Vieira, I. C. G., Vieira, S., Vilanova-Torre, E., Vos, V. A., Wang, O., Zartman, C. E., Malhi, Y. and Phillips, O. L. 2014. Markedly divergent estimates of 
Amazon forest carbon density from ground plots and satellites. Global Ecology and Biogeography, 23, pp. 935-946.

Norden, N., Angarita, H.A., Bongers, F., Martinez-Ramos, M., Granzon de la Cerda, I., van Breugel, M.,Lebrija-Trejos, J., Meave, J.A., Vandermeer, G. B., Williamson, B., Finegan, B., Mesquita, R, Chazdon, R.L. 2015. Successional dynamics in Neotropical forests are as uncertain as they are predictable. Proceedings of the National Academy of Sciences, 112, pp. 8013- 8018.

Daniel, P., Montagnini, F. Thomas, W., Mark, A., Chadwick, O. 2009. Forest recovery after swidden cultivation across a 40 -year chronosequence in the Atlantic forest of southern Bahia, Brazil. Plant Ecology, 205.

Poorter, L., Bongers, F., Aide, T.M., et al. 2016. Biomass resilience of Neotropical secondary forests. Nature 530, 212-225.

Reinmann, A.B., Hutyra, L.B. 2017. Edge effects enhance carbon uptake and its vulnerability to climate change in temperate broadleaf forests. PNAS 114 (1), pp. 107-112.

Remy, E., Wuyts, K., Boeckx, P., Ginzburg, S., Gundersen, P., Demey, A., den Bulcke, J.V., Van Acker, J., Verheyen, K. 2016 .Strong gradients in nitrogen and carbon stocks at temperate forest edges. Forest Ecology Management, 376, pp. 45-58.

Rezende, C.L., Scarano, F.R., Assadd, E.D., Joly, C.A., Metzger, J.P., Strassburgg, B.B.N., Tabarelli, M., Fonseca, G.A., Mittermeier, R.A. 2018. From hotspot to hopespot: An opportunity for the Brazilian Atlantic Forest. Perspectives in Ecology and Conservation, 16 (4), pp. 208-214.

Ribeiro, M.C., Metzger, J.P., Martensen, A.C., Ponzoni, F.J., Hirota, M.M., 2009. The Brazilian Atlantic Forest: How much is left and how is the remaining forest distributed? Implications for conservation. Biol. Conserv. 142, 11411153.

Ribeiro, M.C., Martensen, A.C., Metzer, J.P., Tabarelli, M., Scarano, F., Fortin, M.J. 2011. The Brazilian Atlantic Forest: a shrinking biodiversity hotspot. Pp.405-434. In: Zachos, F.E. \& Habel, J.C. (Eds.). Biodiversity hotspots: distribution and protection of conservation priority areas. New York: Springer.

Rodrigues, R.R., Joly, C.A., Brito, M.C.W., Paese, A., Metzger, J.P., Cassati, L., Nalon, M.A., Menezes, N., Ivanauskas, N.M., Bolzani, V., Bononi, V.L.R. 2008. 
1 Diretrizes para conservação e restauração da biodiversidade no Estado de

2 São Paulo. Governo do Estado de São Paulo, São Paulo.

3 Romitelli, I., D'Albertas, F., Costa, K., Vieira, S.A., Metzger, J.P. Tropical forests

4 in human-dominated landscapes present low biomass stocks and high

5 spatial variability, in prep.

6 Silva, WG., Metzger, JP., Simões, S., Simonetti, C. 2007. Relief influence on the

7 spatial distribution of the Atlantic Forest cover on the Ibiúna Plateau,

$8 \quad$ SP. Braz. J. Biol., 67 (3), pp.403-411.

9 Smith, I.A., Hutyra, L.R., Reinmann, A.B., Marrs, J.K., Thompson, J.R. 2018.

10 Piecing together the fragments: elucidating edge effects on forest carbon

11 dynamics. Frontiers in Ecology Environmental, 16(4), pp. 213-221.

12 Tabarelli, M., Aguiar, A.V., Ribeiro, M.C., Metzger, J.P., Peres, C.A. 2010.

13 Prospects for biodiversity conservation in the Atlantic Forest: Lessons from 14 aging human-modified landscapes. Biol. Conserv. 143, 2328-2340.

15 Urbazaev, M., Christian, T., Cremer, F., Dubayah, R.,M., Markus, R., Christiane, $16 \quad$ S.2018. Estimation of forest aboveground biomass and uncertainties by 17 integration of field measurements, airborne LiDAR, and SAR and optical 18 satellite data in Mexico. Carbon Balance and Management, 13 (5).

19 Vieira, S.A., Alves, L.F., Duarte-Neto, P.J.M, Martins, S.C., Veiga, L.G., 20 Scaranello, M.A., Picollo, M.C., Camargo, P.B., do Carmo, J.B., Neto, E.S., 21 Santos, F.A.M., Joly, C.A., Martinelli, L.A. 2011. Stocks of carbon and nitrogen and partitioning between above- and belowground pools in the Brazilian coastal Atlantic Forest elevation range. Ecol. Evol. 1, 421-434. 